\title{
PLANO DE MARKETING ESCOLA PARQUE BARRA
}

\author{
MIGUEL SOARES MACHADO
}

\author{
RELATÓRIO FINAL \\ ESTÁGIO SUPERVISIONADO
}

CENTRO DE CIÊNCIAS SOCIAIS

CURSO DE GRADUAÇÃO
DEPARTAMENTO DE ADMINISTRAÇÃO

Rio de Janeiro, Julho, 2006

IAG - INSTITUTO DE ADMINISTRAÇÃO E GERÊNCIA ESCOLA DE NEGÓCIOS DA PUC-Rio

http://www.puc-rio.br/iag 


\title{
MIGUEL SOARES MACHADO
}

PLANO DE MARKETING ESCOLA PARQUE BARRA

\author{
RELATÓRIO FINAL \\ ESTÁGIO SUPERVISIONADO
}

Orientador: Luiz Paulo Moreira

Área: Marketing

DEPARTAMENTO DE ADMINISTRAÇÃO

Julho, 2006 
Dedico esta monografia a minha família, que sempre me apoiou em todos os momentos da minha vida. A Diretoria e os funcionários da Escola Parque Barra pela atenção e carinho. E aos meus amigos, sempre presentes. Em especial, à memória de Renato Bastos. 


\title{
PLANO DE MARKETING ESCOLA PARQUE BARRA
}

\author{
MARKETING PLAN ESCOLA PARQUE BARRA
}

\author{
MIGUEL SOARES MACHADO
}

\author{
Luiz Paulo Moreira Lima
}

\begin{abstract}
RESUMO:
A Escola Parque é uma empresa da área escolar estabelecida no município do Rio de Janeiro, Brasil. Atualmente opera com uma unidade na Gávea e outra na Barra da Tijuca, alvo do presente estudo. A unidade, situada na região oeste da cidade, vem apresentando desde o início das atividades, há cinco anos, um resultado empresarial positivo. Os diretores decidiram pela expansão, e este trabalho cientifico investiga as características da demanda do mercado potencial e qual a melhor maneira de atingi-la.

O resultado é um Plano Estratégico de Marketing, com possibilidades de aplicação prática, que indica objetivos a serem alcançados para que a empresa posicione-se estrategicamente no seu mercado de atuação.
\end{abstract}

\begin{abstract}
:
Escola Parque is a Brazilian company in school area, established in the city of Rio de Janeiro, Brazil. Nowadays operates with one unity in the neighborhood of Gávea and one unity in Barra da Tijuca, goal from this document. The unity, located in the west area, has a recent positive history in your financials. The directors have decided to expand, and this scientific sheet investigates the characteristics from the demand and how to reach then.

The result is a Strategic Marketing Plan, with practical application possibility, that indicates the targets to be achieve, so the company is able to positioned strategically in your market.
\end{abstract}

PALAVRAS-CHAVE:

Marketing Educacional, Plano de Marketing e Ensino Básico.

KEYWORDS:

Educational Marketing, Marketing Plan e Basic School.

ÁREA:

Marketing Estratégico 


\section{SUMÁRIO}

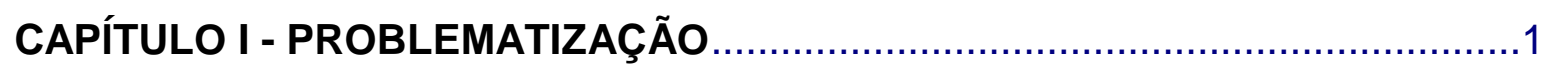

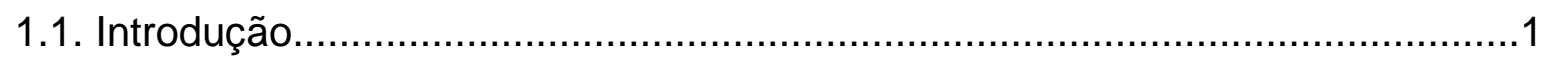

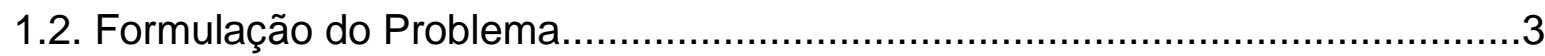

1.3. Objetivo Principal do Estudo......................................................................

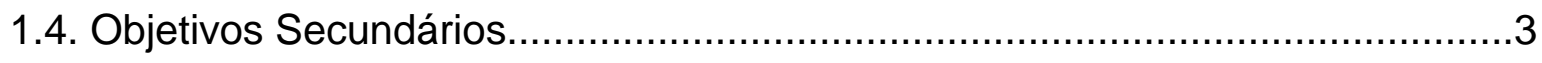

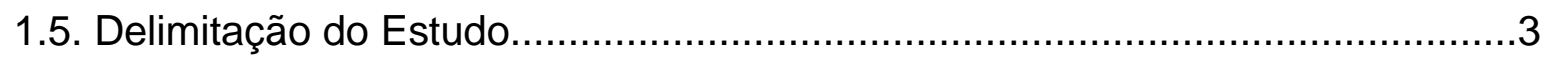

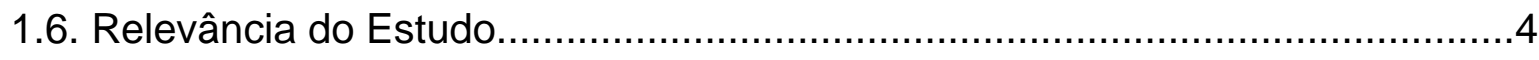

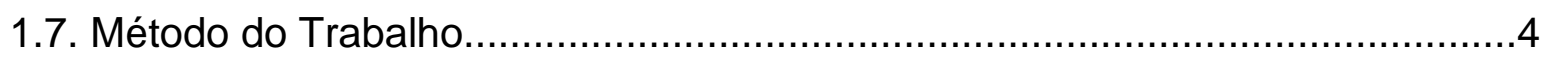

CAPÍTULO II - METODOLOGIA DA PESQUISA ............................................

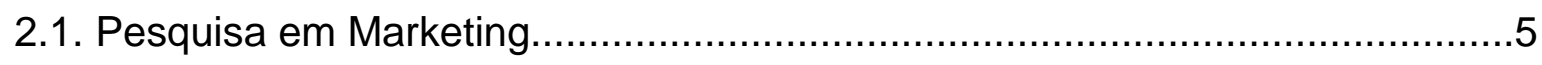

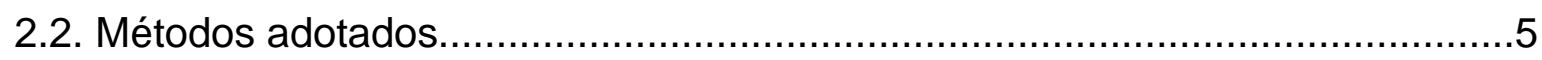

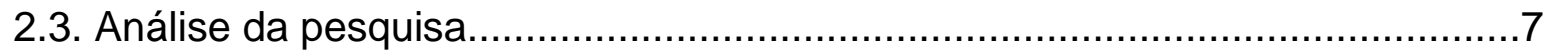

CAPÍTULO III - REVISÃO BIBLIOGRÁFICA ..............................................

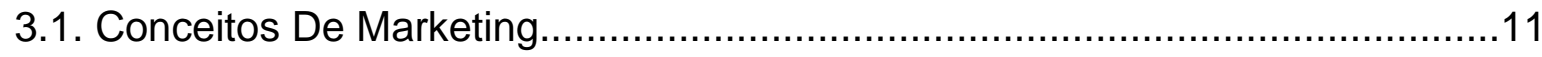

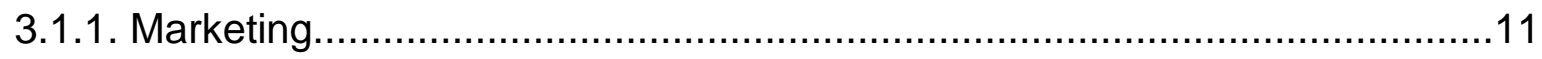

3.1.2. Marketing de Serviços......................................................................12

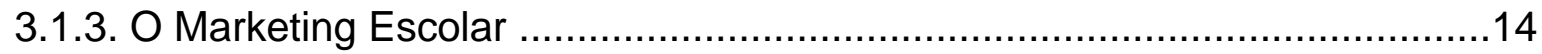

3.1.4. Comportamento do Consumidor ............................................................. 18

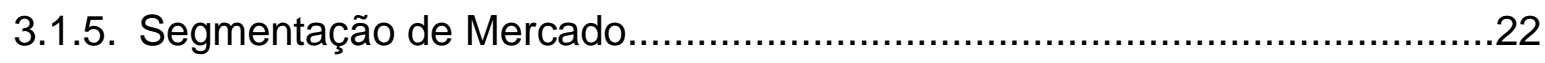

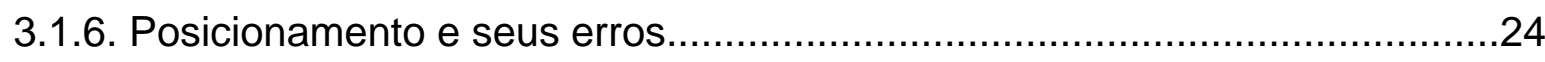

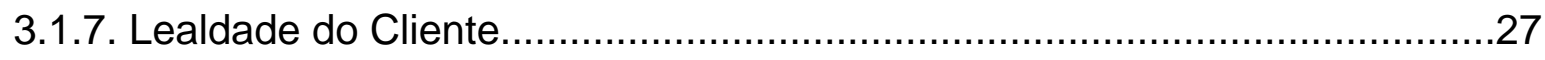

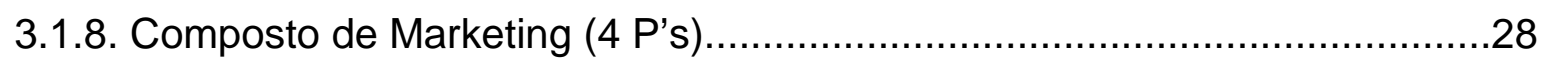

3.1.9. Estudo de casos no Mercado Carioca........................................................30

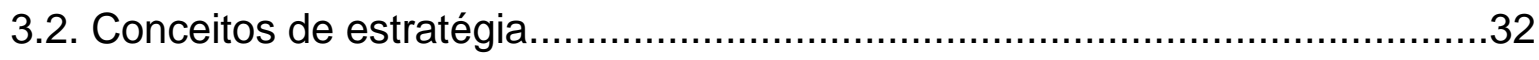

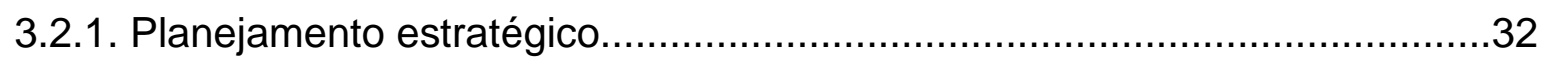

3.2.2. Análise do ambiente externo (Porter) ....................................................33

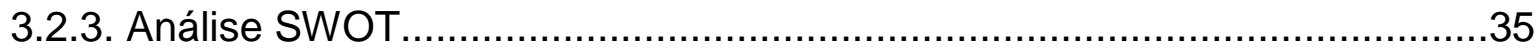


3.2.4. Matriz de crescimento / participação........................................................37

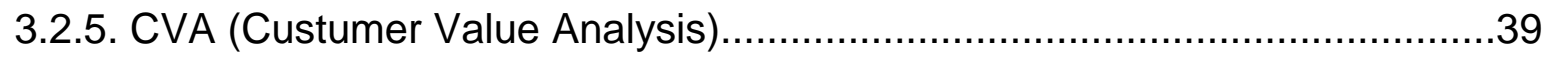

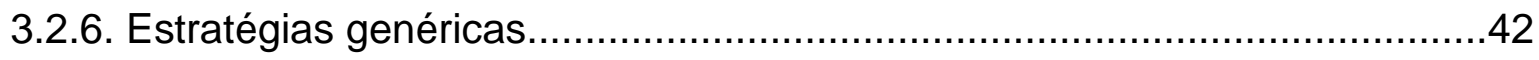

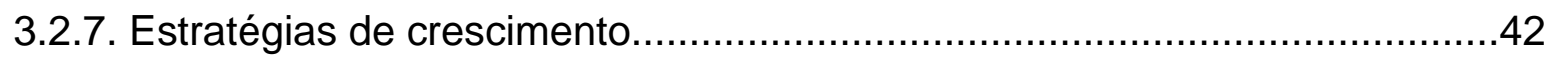

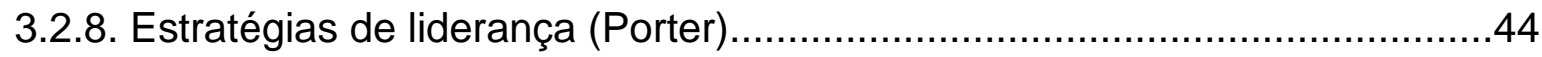

CAPÍTULO IV - PLANO ESTRATÉGICO DE MARKETING ...............................45

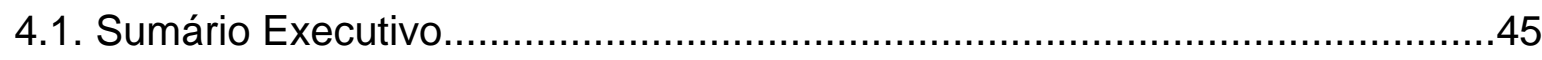

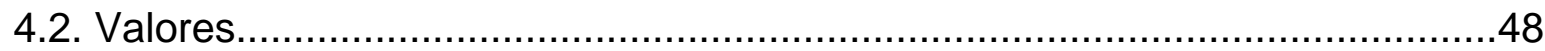

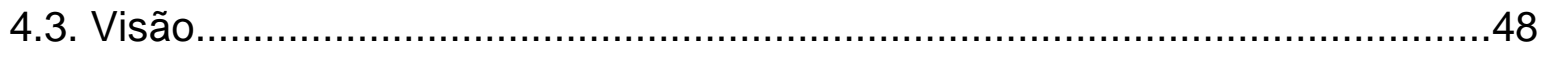

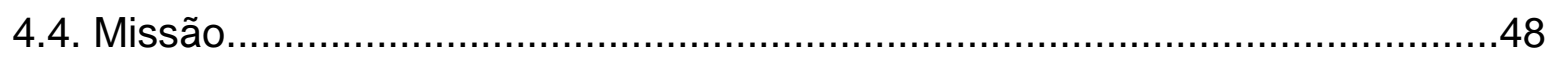

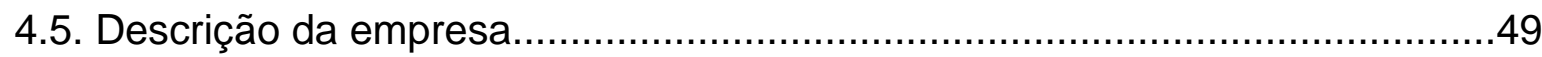

4.6. Estágio de desenvolvimento .....................................................................

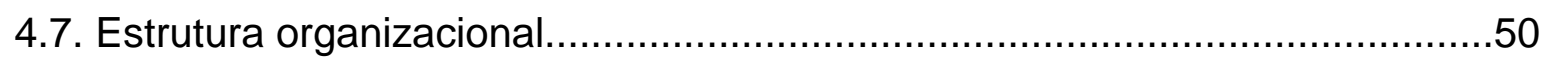

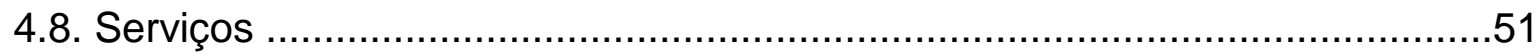

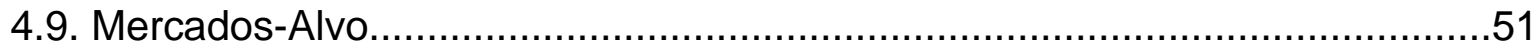

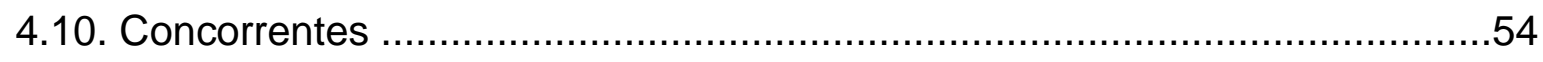

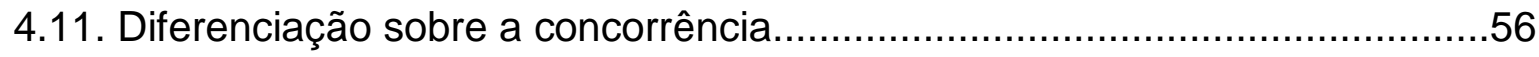

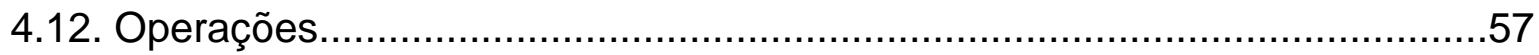

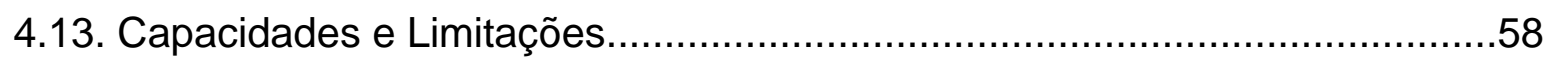

4.14. Análise dos recursos da empresa e Administração......................................58

4.15. Estilo de administração e clima organizacional...........................................59

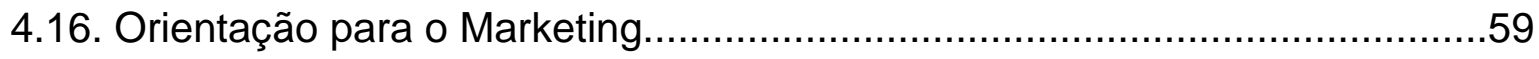

4.17. Comportamento com a gestão ambiental e a responsabilidade social..........60

4.18. Resumo do desempenho da unidade da barra............................................61

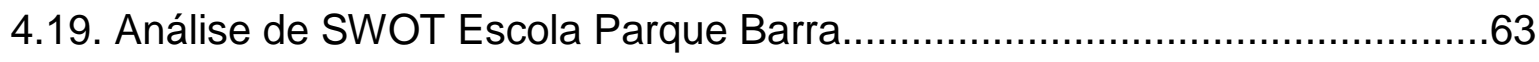

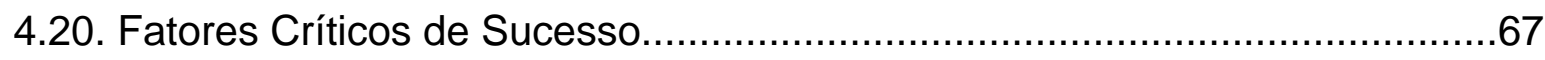

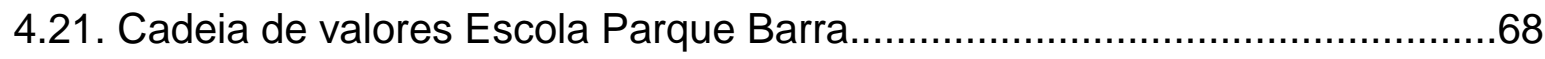

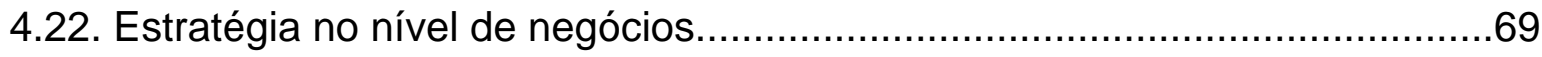


CAPÍTULO V - CONCLUSÕES / RECOMENDAÇÕES.

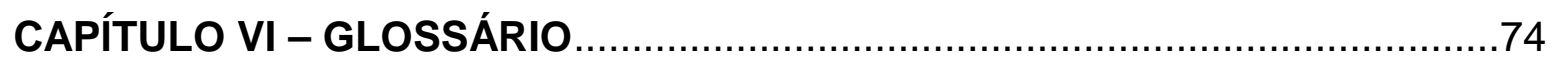

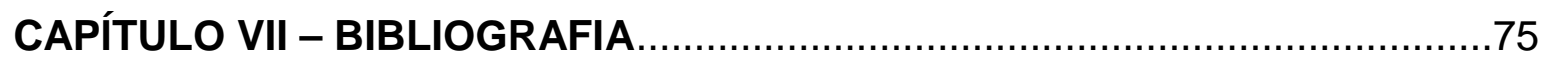

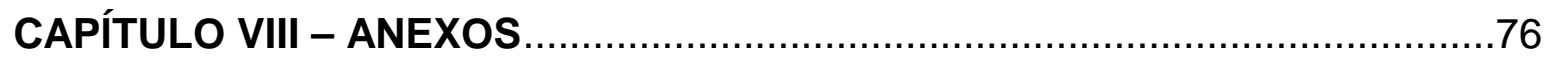




\section{LISTA DE TABELAS E QUADROS}

Tabela 3.1.Atributos da Qualidade ..............................................................

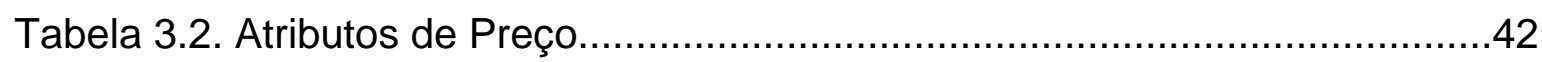

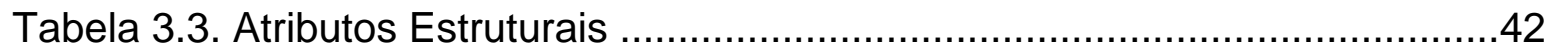

Tabela 3.4. Pontuação Final...................................................................... 42

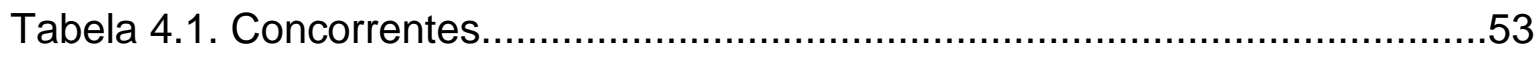

Quadro 4.1. Projeção Número de turmas Escola Parque Barra............................48 


\section{LISTA DE GRÁFICOS E FIGURAS}

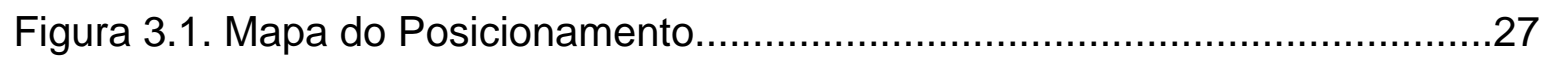

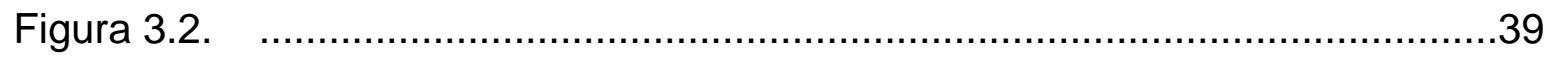

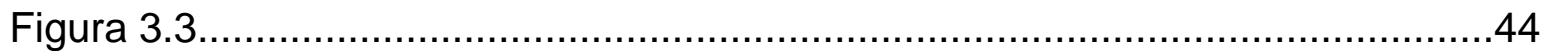




\section{CAPÍTULO I - PROBLEMATIZAÇÃO}

\subsection{Introdução}

A Escola Parque foi fundada em 1970 por um grupo de educadores de diversas áreas do conhecimento. O espaço físico, amplo e "verde", era fundamental para a realização do Projeto Pedagógico. O bairro da Gávea, no município do Rio de Janeiro, possuía este espaço com um casarão que foi adaptado às estruturas necessárias a uma escola e tal espaço era parte integrante do Projeto Pedagógico.

Na época, o primeiro desafio a superar foi justamente a localização da escola, que era considerada afastada da zona sul. Havia a necessidade de transmitir aos pais a importância do "verde" e do espaço amplo na educação dos seus filhos. O padrão da época privilegiava fatores como localização, concentração de pessoas e outras facilidades.

A estratégia escolhida foi apresentar a pais e alunos o local da escola, através de slides em reuniões, ressaltando o espaço e as vantagens que esse diferencial agregava no desenvolvimento de uma criança. Havia uma preocupação inicial de que não se teria o controle necessário das crianças em um espaço tão grande, problema que foi rapidamente vencido e que, mais tarde, tornar-se-ia uma das marcas da Escola Parque.

A Escola Parque, pela necessidade que os pais demonstravam na ocasião de discussão de problemas educacionais, sociais e comportamentais, acabou assumindo a identidade de um espaço onde discussões eram travadas. Os pais encontraram no ambiente da escola um local para a exposição de suas idéias, contribuindo com a construção do projeto pedagógico. Com pouco tempo de mercado, a Escola Parque se tornava uma referência para famílias de nível intelectual considerado alto e de classes econômicas média e alta.

Na década de 1980, a escola encontrou seu segundo grande desafio. Era necessário dissociar a imagem educacional de uma escola de vanguarda da idéia de 
uma instituição com poucos limites e normas. A empresa procurou, então, ajuda específica e técnica para definir sua imagem junto ao cliente e, como conseqüência, acabou se tornando referência de vanguarda no estudo e interpretação da Teoria Construtivista.

Com papel e perfil definidos, a Escola Parque tornou-se também foco de interesse da mídia, sendo procurada para diversos assuntos na área de Educação. A assessoria de imprensa passou a assumir papel importante como ferramenta de marketing, filtrando as reportagens de acordo com a imagem pretendida.

Em 1990, novos profissionais e um administrador profissional foram incorporados à equipe, o que possibilitou um crescimento da escola de forma planejada e estruturada. Pesquisas de mercado e padronização de alguns processos foram realizadas e a Escola Parque, que até então só possuía classes até a quarta série do Ensino Fundamental, iniciou neste período seu processo de expansão. O projeto previa o acréscimo de uma série a cada ano, finalizando sua verticalização em 1997 com a formatura de sua primeira turma do Ensino Médio.

O processo de expansão e consolidação foi realizado através de uma parceria entre diretoria e professores. Cientes da grande concorrência existente no mercado, ambas as partes assumiram o compromisso de cooperação mútua. Uma programação, ainda que tímida, de participação nos lucros, salários-hora acima do mercado e, principalmente, uma participação direta na condução do projeto pedagógico resultaram em resultados expressivos obtidos pela primeira turma que realizou provas de vestibulares. Sem experiências prévias com esta faixa de idade, a empresa comemorou o sucesso do projeto, unindo sua imagem "intelectual" no mercado com resultados práticos e reconhecidos pela sociedade em geral.

Estabilizada no mercado, com seu crescimento concluído verticalmente, e já com mentalidade e estrutura empresarial definidas, a abertura de uma filial na Barra da Tijuca ocorreu de forma natural. Em 2001, portanto, a empresa inaugurou no Condomínio Pedra de Itaúnas. Com planejamento físico-financeiro bem estruturado e divulgação bem realizada, a sede da Barra surpreendeu positivamente os diretores e sócios, com uma demanda maior que a esperada. 
A concepção de que uma tradicional escola da Zona Sul, com um modelo de sucesso de educação e resultados, agora estava oferecendo seu serviço na Barra da Tijuca, foi bem aceita pelo mercado. Os instrumentos utilizados foram, basicamente, reuniões em condomínios, coquetéis de lançamento, contratação de uma assessoria de imprensa e textos pedagógicos em jornais do bairro.

\subsection{Formulação do Problema}

$\mathrm{Na}$ unidade da Barra da Tijuca há uma percepção empírica de demanda reprimida. Apesar da decisão pela expansão já ter sido feita, não se estudou o tamanho, as necessidades e o tipo da demanda do segmento, para assim poder atendê-la da melhor e mais viável maneira possível.

\subsection{Objetivo Principal do Estudo}

Propor um Plano Estratégico de Marketing com base teórica que sirva como elemento de discussão na empresa.

\subsection{Objetivos Secundários}

Conhecer as reais possibilidades de expansão da unidade da Barra da Tijuca, estabelecer os segmentos de mercado-alvo e definir os produtos oferecidos.

\subsection{Delimitação do Estudo}

Entendimento de forma teórica a demanda reprimida na unidade da Barra da Tijuca, limitando-se à esfera teórica acadêmica de nível de graduação.

A área de estudo é restrita aos bairros da Barra da Tijuca e do Recreio dos Bandeirantes. 


\subsection{Relevância do Estudo}

A conclusão do presente estudo acumula conhecimento no ramo de educação escolar e tem importância para os stakeholders ligados a Escola Parque, como os pais, alunos, funcionários e fornecedores. Para os diretores da empresa, existe a possibilidade de aplicação prática. $\mathrm{Na}$ área de educação, a análise serve como base para futuros estudos.

\subsection{Método do Trabalho}

O estudo é composto pela demonstração do conhecimento teórico e a posterior inter-relação com uma proposta de prática profissional. 


\section{CAPÍTULO II - METODOLOGIA DA PESQUISA}

\subsection{Pesquisa em Marketing}

Para efetuar uma venda ou atrair um possível consumidor para um negócio, é fundamental que se saiba o que o cliente deseja e o que ele não deseja. É esta necessidade que justifica a pesquisa de mercados. As experiências passadas e as intuições dos envolvidos nas empresas, no entanto, não devem ser deixadas de lado.

A elaboração de estratégias de marketing por empresas compreende, na maioria dos casos, em estudos sobre oportunidades e/ou problemas específicos. Para fundamentar o processo de tomada de decisões em uma empresa solicitam-se pesquisas de mercado, testes de preferências de um produto, apreciação dos clientes a respeito de um serviço, previsão de vendas ou de consumidores eventuais por região ou a avaliação da propaganda.

Pesquisa de marketing congrega elaboração, coleta, análise e construção de relatórios sistemáticos de dados e informações relevantes sobre uma situação específica de marketing. A pesquisa de marketing procura desvendar os comportamentos, caprichos, fantasias e preferências dos consumidores.

Considerado de uma maneira ampla, a pesquisa em marketing pode englobar, ainda, os regulamentos legais, a estrutura do mercado, as tendências econômicas, os avanços tecnológicos, a situação dos competidores e inúmeros outros fatores.

\subsection{Métodos adotados}

O método adotado neste estudo foi a pesquisa descritiva com coleta de dados primários e secundários. Os dados secundários foram pesquisados nos registros da 
empresa e por dados disponíveis no acervo de domínio público, sendo agrupados de acordo com o objetivo do estudo.

$\mathrm{Na}$ coleta dos dados primários foi utilizado o Survey, com verificação transversal, em pesquisa de campo e por correio eletrônico. Os dados primários foram coletados, também, através de entrevistas e relatos dos diretores da empresa e de funcionários da mesma.

\section{Dados secundários pesquisados:}

Taxa de ocupação das vagas (2002 a 2006). Levantamento realizado nos arquivos da empresa por segmento da educação do ensino básico (Educação Infantil, Ensino Fundamental e Ensino Médio) (Anexo 01).

Taxa de Visitas x Matrículas (2003 a 2006). Levantamento realizado nos arquivos da empresa por segmento da educação do ensino básico (Educação Infantil, Ensino Fundamental e Ensino Médio) (Anexo 02).

Comparativo das Profissões dos clientes entre as Unidades Barra e Gávea (2006). Recolhimento das fichas cadastrais e tabulação dos dados (Anexo 03).

Distribuição Geográfica dos alunos Escola Parque Barra (2006). Recolhimento das fichas cadastrais e tabulação dos dados (Anexo 04).

Crescimento Populacional dos Bairros-Alvo. Cálculo da estimativa para 2007 com dados disponíveis ao público (Anexo 05).

Escolas Particulares no estado do Rio de Janeiro com acesso à Internet (2003). Pesquisa realizada nos arquivos da FENEP (Federação Nacional de Escolas Particulares) (Anexo 06).

Pesquisa de satisfação Escola Parque Barra. Pesquisa contratada junto à empresa "Confirma", em outubro de 2004 (Anexo 07). 


\section{Dados primários pesquisados:}

Preferências do público-alvo (Anexo 08). Elaboração, aplicação e conclusão de um questionário direcionado a pais de alunos com idades entre 2 e 17 anos, residentes nos bairros da Barra da Tijuca e do Recreio dos Bandeirantes, que em algum momento procuraram como opção a Escola Parque Barra, mas não efetuaram a matrícula. Sendo o estudo limitado a esfera acadêmica de graduação, a pesquisa não possui amostra suficiente para aplicações práticas na organização, merecendo, portanto, ser aprofundada.

\subsection{Análise da pesquisa}

As informações levantadas pelas pesquisas permitem as seguintes conclusões:

Taxa de ocupação das vagas acima do esperado. Em 2006, a Escola Parque Barra atingiu o nível de 95\% na relação Capacidade / Alunos. Em 2005, este número chegou a 98\%, e em 2003 já era de 95\%. Deve-se avaliar, no entanto, a quantidade absoluta das vagas oferecidas, que em 2003 estava em 220 e que em 2006 subiu para 689 vagas. A quinta pergunta da pesquisa (survey) realizada por telefone também ajuda a justificar os $5 \%$ de vagas a serem preenchidas. Neste item, $50 \%$ dos pais afirmaram ser importante que o filho curse a Educação Infantil, Educação Fundamental e Ensino Médio na mesma escola, revelando a tendência de matrícula de alunos mais novos. De fato, a taxa de ocupação de vagas, em 2006, para o Ensino Médio foi de 71,25\%.

Os números alcançados são superiores aos esperados pelos diretores e confirmam a percepção empírica da demanda reprimida para o serviço oferecido pela Escola Parque Barra.

Perfil mais técnico das famílias na unidade Barra. $O$ ranking das ocupações profissionais das famílias de pessoas matriculadas na Escola Parque apresenta a mesma ordem, tanto na Gávea como na Barra, com administradores em 
primeiro lugar e profissionais ligados à classe artística em segundo. No entanto, percentualmente nota-se a manifestação do perfil técnico-administrativo mais presente na unidade da Barra, enquanto na Escola Parque Gávea, um perfil mais "cultural-artístico".

Associando este fato com os relatos dos diretores da empresa, pode-se concluir que as famílias que buscam a Escola Parque Barra têm o desejo de "adquirir cultura", entendendo que a Escola Parque Barra é uma possível fornecedora deste anseio. Sendo assim, as famílias projetam na empresa uma referência cultural e intelectual na região.

\section{Concentração geográfica nos bairros da Barra da Tijuca e Recreio dos}

Bandeirantes. A verificação da distribuição geográfica das residências dos alunos confirma que o público-alvo da Escola Parque Barra está na Barra da Tijuca e Recreio dos Bandeirantes, uma vez que 92\% dos alunos residem em um desses bairros.

Crescimento populacional nos bairros-alvos. Os bairros mencionados anteriormente ainda possuem ocupação recente em relação aos outros bairros do município do Rio de Janeiro e estão entre os que mais crescem.

Tendência a "commoditie" do acesso à Internet. A análise dos índices de acesso à Internet na rede privada aponta para um cenário no curto prazo, onde a disponibilização de ferramentas de informática será comum a quase totalidade das instituições. Desta maneira, a aplicação prática e a interface com a informática ganham papel de destaque, em detrimento ao equipamento. A Escola Parque Barra, como referência cultural e intelectual que pretende ser, tem que estar preparada para este cenário tecnológico de futuro.

Baixo nível da satisfação no atributo “informática”. É a comprovação prática do item anterior. Foi atribuída a pior nota de satisfação para informática na Escola Parque Barra. A empresa, no entanto, possui computadores nas salas de aula, laboratório e preocupação com a atualização tecnológica, apontando mais uma vez para um mercado cada vez mais exigente nesta área. 
Características valorizadas mais pessoais do que profissionais. As mães dos alunos da Escola Parque Barra, quando questionadas sobre as qualidades que mais valorizavam nos profissionais que lidavam com seus filhos, concentraram suas respostas nos relacionamentos pessoais. Talvez seja natural para uma empresa de serviços a grande importância do pessoal de frente, mas há que se ressaltar o perigo da associação da instituição as pessoas que nela trabalham. Mais a frente, no item 3.1.9, alguns exemplos servem como base de discussão mais aprofundada.

Valorização do projeto pedagógico. Em contrapartida ao item anterior, a metodologia de ensino é apontada por 38\% das mães como a qualidade que mais apreciam na Escola Parque Barra. É a comprovação de que a empresa está atingindo seu nicho de mercado, que busca um projeto pedagógico com conteúdo aprimorado e atualizado (item 4.1.6). Esta percepção dos clientes atuais precisa ser instituída nos demais clientes em potencial.

Importância da variável "preço". A investigação da percepção empírica dos diretores, através da pesquisa realizada com as famílias que já haviam procurado a Escola Parque Barra, revelou que diferentemente do que os diretores acreditam, o preço praticado pela empresa é fator preponderante na escolha da instituição escolar. De fato, aceitam pagar uma mensalidade acima da média do mercado, no entanto entendem que é um investimento, e, portanto exigem "retorno". Desta forma, deve ser cuidadoso o processo de precificação das mensalidades, sempre avaliando o custo-benefício oferecido.

Importância da variável "localização". A pesquisa revela que, aproximadamente, $60 \%$ dos entrevistados consideram a distância máxima de dez quilômetros para matricular o filho em uma escola. A concentração das respostas não chega a ser suficientemente grande para se deduzir como uma regra de mercado, mas revela uma tendência que pode ser utilizada nas ações de marketing ou na melhora da oferta do transporte escolar.

Tradição. A história da instituição e o que representa para o mercado são importantes elementos no processo de escolha, segundo os pais entrevistados. De fato, a Escola Parque Barra utilizou o bom nome no mercado da marca "Escola 
Parque" para desenvolver-se na Barra da Tijuca e Recreio dos Bandeirantes. O custo de mudança de uma escola para outra é relativamente grande, pois envolve tempo, mudança de hábitos e costumes, interrupção do processo pedagógico e, principalmente, a ruptura do círculo social dos filhos. Desta forma, é natural que as famílias optem por instituições mais "sólidas" e confiáveis no longo prazo.

Cabe, portanto, aos diretores da Escola Parque Barra investir continuamente na força da marca sem, no entanto, abdicar do desenvolvimento de uma identidade própria para a unidade.

Continuidade na mesma escola. Na pesquisa com os pais, $50 \%$ dos entrevistados consideraram importante o filho cursar na mesma escola a Educação Infantil, o Ensino Fundamental e o Ensino Médio, enquanto 25\% não consideraram essa questão importante e outros $25 \%$ se mostraram indiferentes. Se por um lado esse resultado indica a importância e o diferencial de se ofertar a grade curricular completa, por outro, ele revela que o público potencial não é restrito a alunos ingressantes mais novos como visto em item anterior. Deve-se enxergar como cliente potencial todos os jovens com idade escolar, e não apenas os mais novos, ou ingressantes em início de segmento. O projeto pedagógico deve, inclusive, estar preparado para recebê-los.

O projeto pedagógico é conhecido. Apesar de os diretores suporem que o projeto pedagógico não é claro para o público geral, $80 \%$ dos entrevistados (lembrando que não são pais de alunos da Escola Parque) saberia descrever o projeto da Escola Parque Barra. O possível erro de subposicionamento da marca (item 3.1.6) apontado pelos diretores não está relacionado com este atributo, ainda que a pesquisa por telefone possua distorções, principalmente em questões subjetivas. 


\section{CAPÍTULO III - REVISÃO BIBLIOGRÁFICA}

\subsection{Conceitos de marketing}

\subsubsection{Marketing}

Evidentemente, sempre existiu marketing. No entanto, a maneira como o termo é conceituado atualmente é um processo recente. Data de 1954 o livro de Peter Drucker "A Prática da Administração", ainda não um livro de marketing, mas que o cita como instrumento importante a ser considerado pelas empresas. Em 1960, Theodore Levitt publicou o artigo "Miopia de Marketing", no qual, estudando uma série de erros de percepção da relação empresa-cliente, ressalta a importância da satisfação do cliente. A transformação resultante deste artigo foi tanta que seu autor foi intitulado o "pai do marketing" (KOTLER, 1994)

A "American Marketing Association" sugere como definição de marketing, "uma função organizacional e um conjunto de processos para criar, comunicar e entregar valores aos clientes e para administrar o relacionamento com o cliente de forma a beneficiar a organização" (American Marketing Association, 2004).

Kotler privilegia uma definição social em contraste a uma definição organizacional, salientando o papel desempenhado pelo marketing na sociedade. Define marketing como "uma atividade direcionada para satisfazer necessidades e desejos através de processos de troca”. (KOTLER, 2000)

Encontra-se na bibliografia muitas definições de marketing. Em geral, as definições abordam a maneira que a empresa estabelece a relação com o cliente, como o entende e como é feito o processo de troca entre as partes. Basicamente, o marketing alcança grande relevância nas empresas, quando a oferta passa a ser uma variável menos importante do que a demanda. Ou seja, o cliente passa a ser figura central no processo de troca. Desta forma, o estudo aprofundado do marketing proporcionou a ramificação de diferentes tipos de abordagem. Marketing de produtos, de serviços, social e relacionamento são alguns exemplos. 


\subsubsection{Marketing de Serviços}

Serviço é um ato ou desempenho oferecido por um agente a outro. Não envolve a criação de um produto físico, embora este possa estar presente na ação, como, por exemplo, no transporte.

É imensa a gama de serviços oferecidos ou necessários à sociedade, incluindo a maior parte dos serviços públicos, a atividade dos profissionais liberais, transações financeiras, atividades ligadas ao lazer e ao turismo, transportes, comunicações em geral, atividades culturais, a informática e muitas outras atividades.

Hoje, o setor de serviços constitui mais de 50\% do Produto Interno Bruto (PIB) mundial, especialmente em paises altamente desenvolvidos, como nos Estados Unidos (72\%) e Canadá (67\%). Há uma relação entre o aumento da participação dos serviços no PIB e a industrialização (Fundo Monetário Internacional in "Panorama econômico mundial, 2001"). À medida que aumenta a participação da indústria, observa-se a diminuição da agricultura e o aumento da participação proporcional dos serviços. O Brasil, pelas suas características continentais apresenta, quando comparado a outros países da América Latina, uma participação média dos serviços na composição do PIB. Enquanto Argentina, Uruguai e México têm uma participação acima de 60\%, o Brasil apresenta apenas 52\% (Banco Mundial, 2001). Por um lado, isto se deve à grande importância da agricultura brasileira, mas por outro sugere que a área de serviços tem uma grande possibilidade de expansão. Outro fenômeno que contribui para um percentual maior nos países desenvolvidos é a deseconomia de escala, ou aglomeração, que desloca indústrias e estruturas para a periferia.

As empresas de serviços são extraordinariamente diferentes quanto a sua origem, função, organização interna e porte. Há, no entanto algumas características comuns entre elas. Evidentemente, existe a necessidade de a empresa encontrar seu destinatário, o consumidor. Após a prestação do serviço, é plausível se supor que o consumidor deva ficar satisfeito. A constatação de que a melhoria da qualidade - mesmo em setores acessórios à atividade final - era boa para o negócio e fundamental para a competitividade, levou as empresas a privilegiarem 0 
atendimento aos consumidores, bem como a aperfeiçoarem técnicas de marketing e de gerenciamento interno.

O encontro com o consumidor está inerente a uma empresa de serviço. Muitas vezes, ela trabalha com o produto proveniente da indústria, mas também com bens não-tangíveis, cujas matérias-primas básicas são as necessidades, os sonhos e os desejos dos clientes. Esta relação se dá, em maior ou menor grau, independentemente do serviço ser provido por um vendedor de rua ou por um gigante financeiro.

O marketing de serviços se distingue em alguns aspectos do marketing de produtos. Os serviços são intangíveis, não podem ser estocados e o prestador deve estar em contacto, mesmo que indiretamente, com o cliente. Os serviços, ao contrário dos produtos, tendem a apresentar variações em termos de qualidade e eficiência. O marketing de serviços pode ser definido como as atividades operacionais destinadas a investigar, obter e servir a demanda por assistência profissional. Nestas atividades incluem-se as tarefas de desenvolvimento e promoção de serviços pessoais e comunitários.

O ramo educacional está dentro do setor de serviços, e o contato pessoal com os clientes é cotidiano e intrínseco ao negócio. O pessoal de frente tem papel destacado no ramo escolar. O desempenho de professores e coordenadores é a manifestação física da entrega do serviço. Evidências físicas ficam por conta de diplomas, boletins e relatórios. A confiança é fundamental nesta área, e as reuniões de pais são meios de transmitir esta segurança.

Um grande desafio no ramo educacional é o valor percebido do serviço pelo cliente. A formação do aluno não é possível de ser medida em um dia, mês ou até mesmo um ano. Nem ao menos existem índices confiáveis que apontem para uma bem sucedida formação. Desta forma, é necessário que exista um feedback contínuo para pais e alunos, para que estes possam avaliar a qualidade do serviço prestado. 


\subsubsection{O Marketing Escolar}

Baseado na experiência norte-americana, o autor Phillip Kotler estuda os problemas enfrentados por instituições educacionais, assinalando o aumento da concorrência nas escolas particulares de Ensino Médio e Fundamental, em razão do declínio da escola pública. Muitas escolas foram abertas, mas muitas são concomitantemente fechadas, caracterizando um aumento de concentração do mercado e o aumento da concorrência.

Diante deste novo contexto de mercado, as instituições escolares, que tradicionalmente não adotam uma gestão profissional, têm recorrido a diversas estratégias, como aumentar a propaganda, diminuir os gastos, e oferecer cursos alternativos.

A estratégia mais promissora é o investimento em marketing. Mesmo as bem sucedidas escolas particulares devem planejar agora seu desempenho futuro, evitando o que ocorreu com as faculdades, que assistiram à queda do número de matrículas, pressão financeira e futuro incerto. As causas são diversas, mas a administração mal conduzida e ingênua é, sem dúvida, um elemento que merece atenção cuidadosa. Crescimentos sem planejamento, transição deficiente de líderes e crises financeiras, posteriormente descrito no item 3.1.9, são exemplos de problemas que as instituições convivem. Todos estão ligados à falta de planejamento, de visão empresarial e conhecimento de mercado, ou seja, à falta de uma gestão profissional que utilize as ferramentas que o marketing oferece.

No Brasil atual, existe uma reconhecida grave crise na rede privada de educação. A redução do número de alunos é calculada em $25 \%$ nos últimos cinco anos. Vagas ociosas no ensino superior já somam 35\%. No ensino médio, a situação é mais crítica: em São Paulo, a cada mês, cerca de sete escolas fecham ou pedem falência. Para reverter este processo, o ensino privado, ampliou o investimento em marketing no último qüinqüênio. Este ano, este investimento deve atingir a marca dos $\mathrm{R} \$ 450$ milhões, com um crescimento de $17 \%$ ao ano (www.revistamarketing.terra.com.br/index.php - 28/06/2006). 


\section{Marketing e as escolas}

A pressão dos consumidores, com suas necessidades que variam com 0 tempo, obriga os administradores educacionais a profissionalizar sua gestão. As ferramentas desenvolvidas pelo marketing são caminhos naturais nas instituições. Ao mesmo tempo, existe cautela por parte de administradores de escolas em relação ao marketing, que seria uma atividade muito dispendiosa e própria de empresas que visam apenas o lucro.

Antes de se discutir sobre o uso do marketing na gestão escolar, é necessário entender o que é o Marketing. Quando se perguntou a 300 administradores escolares cujas entidades apresentavam queda no número de matrículas, o que é marketing, 61\% responderam que marketing é a combinação de venda, propaganda e relações públicas. Outro $28 \%$ consideraram marketing como apenas uma destas atividades. Apenas uma minoria respondeu que marketing tinha a ver com a avaliação das necessidades, o desenvolvimento do produto, adequação do preço e a distribuição (KOTLER, 1994). A noção mais comum é que o marketing tem a ver com a venda e sua promoção, não considerando que a venda em si não pode ser separada de cadeia de atividades que é o marketing em si. A venda e o lucro obtido são apenas aspectos da transação. Pode-se presumir que sempre haverá necessidade de algum esforço de vendas, mas o objetivo do marketing é tornar a venda supérflua. $\mathrm{O}$ grande mérito do marketing é conhecer tão bem o cliente que o produto se adapte a ele e se venda por si só (Peter Drucker in Kotler, 2000).

\section{Marketing escolar e orientação de marketing}

A orientação de marketing procura determinar as necessidades e os desejos do mercado alvo e satisfazê-los, empregando as ferramentas características do marketing. No entanto, as instituições escolares não podem ignorar seus objetivos e suas especificidades educacionais. O serviço fornecido por uma escola é apoiado fundamentalmente no aspecto pedagógico. Portanto, o que sustenta um projeto de marketing de uma escola é a qualidade do ensino, a seriedade da proposta, a confiança e a credibilidade da instituição. Quando o mercado alvo está satisfeito, surgirão os comentários favoráveis e a lealdade ao serviço será uma decorrência. Os alunos e as famílias satisfeitas são os maiores agentes de propaganda das escolas. 
O que diferencia o marketing escolar do marketing de serviços é que atender as necessidades e os desejos dos alunos vai além do mero fornecimento de serviços. Os desejos no longo prazo incluem o domínio de informações e habilidades que justifiquem o diploma conquistado. A escola ainda contribui com a sociedade ao preparar pessoas para serem produtivas e assumirem a cidadania. Outro objetivo das escolas é o de inserir os seus alunos no meio social, veiculando sua forma de pensar e sua visão do mundo.

\section{Planejamento de Marketing}

A coleta de informações é tarefa fundamental para que se permita organizar, interpretar e fundamentar as tomadas de decisão. O monitoramento do ambiente de marketing (mercados alvo, canais de marketing, concorrentes, público e forças macro ambientais) fornece dados que alimentam o sistema de informações, fundamentando os administradores de marketing no planejamento e implementação de novos projetos de marketing.

A necessidade do planejamento formal só é reconhecida, na maioria dos casos, quando a instituição se vê em dificuldades. Ideal é o planejamento estratégico anterior ao problema.

\section{Recursos institucionais e de direcionamento}

Duas instituições, com as mesmas condições exteriores, podem ter histórias diferentes. Uma pode prosperar e a outra desaparecer. As instituições escolares diferem em sua história, nas características de seus fundadores, em seus objetivos, nos recursos iniciais disponíveis e em seus projetos.

Recursos tangíveis de uma instituição correspondem aos recursos financeiros, instalações, tecnológicos e funcionários, por exemplo. Os recursos intangíveis são constituídos pela suas idéias e propostas, reputação e sua história. O sucesso da instituição é condicionado pela maneira da instituição em utilizar estes recursos. As seguintes análises devem ser levadas em conta na elaboração do Plano de Marketing: ambiente e caráter institucional, ciclo de vida institucional, potencial para mudança institucional e análise de recursos. 
Ambiente e caráter institucional. É a maneira como a instituição se insere no meio social, pela especificidade de sua proposta e pelos princípios assumidos por seus fundadores. São inevitáveis, pela passagem do tempo, que ocorram modificações e adaptações das propostas originais, mas existe uma tendência a que o direcionamento dos diretores permaneça. O caráter institucional não decorre apenas de fatores ligados aos fundadores, mas também de sua localização geográfica.

A percepção que alunos, professores, funcionários e outros públicos possam ter da instituição deve ser avaliada constantemente. Esta avaliação revela aspectos do meio interno que não venham atendendo convenientemente seu público.

Ciclo de vida institucional. No período inicial, o crescimento da escola tende a ser acelerado. Depois de algum tempo, as taxas de crescimento diminuirão, tornando lento, em um estágio de maturidade. Se a escola não se estabelecer de fato, pode entrar em declínio, podendo até mesmo desaparecer.

Escolas que apresentarem propostas pedagógicas não usuais podem ter um ciclo de vida reduzida, ocasionado por fatores que poderiam ser previstos e corrigidos. Nestes casos, destaca-se a importância da imagem percebida pelos clientes.

Potencial para mudança institucional. A instituição que não se adaptar aos desafios ocasionados pelo passar do tempo, como concorrência de outras instituições mais modernas, desgaste de suas propostas e a rigidez de suas estruturas, pode passar de uma aparente maturidade tranqüila para o declínio.

Algumas instituições, mesmo em dificuldades, resistem a qualquer mudança. Outras optam pela manutenção das tradições, como por exemplo, escolas vocacionais ou escolas que se dirigem para um segmento de público bem definido, como as escolas para estrangeiros.

Análise de recursos. O inventário de recursos de uma instituição irá identificar suas forças e fraquezas. A instituição deve privilegiar as metas, 
oportunidades e estratégias que estejam ao alcance de suas forças, evitando aquelas que lhes sejam excessivas e que seus recursos não sejam suficientes.

\section{Escola Parque Barra}

A experiência da matriz, na Gávea, serviu de aprendizado aos diretores quando perceberam que, para crescer, tinham que profissionalizar sua gestão. A ruptura da administração básica, comandada por antigos professores, para uma administração profissional, foi complicada e lenta. Desta forma, a unidade da Barra da Tijuca nasceu com padrões estabelecidos, objetivos, controle e visão estratégica, ainda que a aplicação prática não seja efetiva em todas as áreas.

A identificação de problemas, como, por exemplo, o posicionamento no mercado já é uma preocupação constante na empresa, mas as soluções são lentas e muitas vezes não aplicadas.

\subsubsection{Comportamento do Consumidor}

Para que os propósitos do marketing se cumpram, é fundamental que se estude o comportamento do consumidor. Isto é, como pessoas, grupos e organizações selecionam e descartam artigos, serviços, idéias ou experiências para satisfazer suas necessidades e seus desejos.

Os principais fatores de influência no processo de aquisição são culturais, sociais, pessoais e psicológicos.

\section{Fatores culturais}

Pode-se definir cultura como as atitudes e comportamento característicos a um grupo social ou organização particular. Os diferentes grupos sociais pensam, sentem e agem diferentemente. A aquisição de valores culturais, percepções, preferências e comportamento de uma família ou de outras instituições, como a escola, se dá continuamente na vida de uma pessoa, desde criança até a idade adulta. Cultura, como um corpo de comportamentos aprendidos comum a uma 
determinada sociedade humana, atua principalmente como um molde, formatando comportamentos ou a consciência que se transmite de geração a geração.

Cada cultura se compõe de sub-culturas, que mantêm suas características básicas, apresentam diferenças em identificação e socialização mais específicas para seus membros. As sub-culturas criam segmentos de mercado, que devem ser compreendidos e analisados pelos profissionais de marketing. As diferenças podem ser classificadas a partir de nacionalidades, religiões, classes sociais, etnias, etc.

As classes sociais são divisões homogêneas e duradouras de uma sociedade, e seus integrantes possuem valores, interesses e comportamento similares. Max Weber formulou uma teoria de estratificação social composta de três componentes: classe, status e partido, como elementos conceituais distintos. Classe se baseia na relação econômica com o mercado e, em última análise, se relaciona com o poder aquisitivo dos seus componentes. Status refere-se a qualidades nãoeconômicas como educação, honra, prestígio e poder. Partido está ligado a fatores como alinhamento a um domínio político ou intelectual.

\section{Fatores sociais}

A decisão de compra do consumidor é influenciada por fatores gerados no seu convívio na sociedade, ou seja, nas relações com outras pessoas ou instituições. O conjunto de pessoas que influenciam de maneira direta ou indireta o comportamento ou as atitudes de uma pessoa constituem os grupos de referência. $\mathrm{O}$ grupo de referência primário mais evidente e por isso mais estudado é a Família. É a mais importante organização de compras e consumo.

Quando a influência é direta, classifica-se o grupo de influência como grupo de afinidade. Muitas vezes, as pessoas pertencem naturalmente a estes grupos, mas gostariam de se agregar a grupos diferentes, constituindo assim grupos de aspiração. Ou, em casos opostos, rejeitam valores e comportamento, constituindo grupos de dissociação.

Dado um cliente-alvo, a identificação de seus grupos de referência orientará fortemente o direcionamento da estratégia mercadológica a ser seguida. Deve se 
levar em conta que a qualidade e a intensidade da influência dos grupos de referência variam consideravelmente entre produtos e marcas. Mas mesmo no marketing de serviços (ou principalmente!) encontram-se fortes indícios de sua importância.

Em princípio, um grupo de referência pode apresentar uma pessoa ou um grupo de pessoas que exercem maior influência sobre os demais componentes do grupo. Um líder de opinião realiza uma divulgação informal, oferecendo conselhos ou informações ou atestando sua experiência em relação a um produto ou serviço.

\section{Fatores pessoais}

Idade, momento da vida, ocupação, status econômico, estilo de vida, personalidade influenciarão as decisões do comprador. Estas variáveis devem ser avaliadas juntamente com fatores sociais e culturais analisados anteriormente na escolha de um produto ou serviço.

\section{Fatores psicológicos}

Os fatores psicológicos influenciam o comportamento do consumidor em quatro linhas predominantes: motivação, percepção, aprendizagem e crenças e atitudes.

O estudo dos motivos psicológicos que movem, particularmente, um consumidor é um dos campos mais importantes para o marketing. Os conceitos de Freud (as forças psicológicas que formam o comportamento são em grande parte inconscientes), Maslow (as necessidades humanas são dispostas em hierarquia, das mais urgentes para as menos urgentes), Herzberg (cada produto ou serviço apresenta fatores motivadores positivos e negativos, satisfatórios e insatisfatórios) e de outros autores ajudam o profissional de marketing na formulação de suas estratégias, fundamentando suas pesquisas.

Cada indivíduo, devido a seu background cultural, psicológico e social, interpretará uma mensagem de forma própria, mas pode-se supor que dentro de um grupo de referência existirá uma percepção predominante ou média. 
A percepção seletiva é a habilidade de o indivíduo filtrar uma informação por razões conscientes ou inconscientes. Calcula-se que uma pessoa seja exposta a mais de 1500 anúncios por dia. Evidentemente, o consumidor só prestará atenção a uma pequena fração destes estímulos. Por meio de uma atenção seletiva ele filtrará os anúncios que lhe interessem. As mensagens que as pessoas retêm constituem uma minoria dentre as mensagens recebidas e filtradas. Provavelmente uma pessoa irá reter informações que vêm ao encontro de suas crenças e atitudes. A reiteração da mensagem ou informação irá reforçar a tendência de uma maior retenção. As pessoas tendem a reter os pontos positivos de um produto de que gosta e a esquecer estes mesmos pontos de produtos que não inspirem simpatia.

À medida que as mensagens conduzam uma pessoa à ação, esta experiência a conduzirá à aprendizagem, que é produzida por meio da interação de impulsos, sinais, respostas e reforços. Sinais são estímulos menores que condicionam a maneira da pessoa agir. A demanda para um produto decorre da aprendizagem condicionada por fortes impulsos, pelo uso de sinais motivadores, seguidos pelo reforço positivo. Já a crença é o conjunto de opiniões e impressões que uma pessoa mantém a respeito de alguma coisa. Podem ter como fundamento conhecimento, opinião ou fé. As crenças estabelecem a imagem de marcas e produtos e as pessoas respondem a esta imagem.

\section{Escola Parque Barra}

A matrícula de um aluno é influenciada por diversos fatores. Em geral, a decisão é dos pais dos alunos, mas, em alguns casos, os filhos, principalmente os mais velhos, têm influência. Os pais escolhem a escola dos filhos movidos por fatores objetivos, como o preço, a distância, o tamanho da instituição, as instalações físicas, a compreensão da proposta pedagógica, o sucesso em vestibulares passados e também por fatores subjetivos, como as relações prévias dos pais com a instituição e a confiança que a instituição desperta. Há uma tendência dos pais a considerarem a escola como a promotora de parte da educação dos filhos, além de fornecedora de habilidades específicas. Desta maneira, é natural que os pais escolham uma instituição que se assemelhe aos seus valores atuais ou a valores desejáveis. 


\subsubsection{Segmentação de Mercado}

Localizar os segmentos de mercado individualizados é uma necessidade e uma realidade na conquista do competitivo mercado atual. Evoluiu-se de estratégias voltadas para o mercado de massas para estratégias que contemplam a segmentação do mercado. Com essa segmentação, procura-se aumentar a precisão do marketing da empresa, caminhando-se assim para o micromarketing que contemple níveis de segmentação, nichos, aspectos locais e individuais.

\section{Marketing de segmento}

Cada segmento deve ter uma identidade, contendo membros com determinada característica e se comportando diferentemente de outros grupos. Estas características são diversas, mas podemos exemplificar a priorização da questão do preço, a localização geográfica, atitudes e hábitos de compra. Assim, pode-se tratar cada segmento separadamente, fornecendo produtos e serviços de especificidades diferentes, preços diferentes e providenciando sua distribuição de forma acessível a estes consumidores-candidatos.

A leitura clara de um segmento permite o desenvolvimento de um marketing mix que vai explorar ao máximo o determinado nicho. Quatro critérios são apontados para que a segmentação adotada se torne efetiva:

Mensurabilidade - Deve ser possível a determinação de valores das variáveis selecionadas para a segmentação com esforços minimizados.

Acessibilidade - O grupo escolhido deve ser passível ser abordado por alguma mídia, devendo-se assim selecionar adequadamente a mídia a ser empregada.

Substancialidade - O segmento tem de ser suficientemente grande.

Operacionalidade - Aplicação eficiente da segmentação. 


\section{Níveis de Segmentação}

Quando estudamos um mercado potencial, temos interesse estratégico em tentar estabelecer, dentro da totalidade de consumidores, quais os grupos que serão mais interessantes em focar. Os profissionais em marketing dividem o universo de consumidores potenciais em diferentes níveis, de acordo com características específicas.

Um primeiro nível de segmentação é geográfico, dividindo-se o mercado em diferentes regiões, estabelecendo-se parâmetros como tamanho, concentração e localização.

O segundo nível é a segmentação demográfica, que envolve as características pessoais. O problema desta divisão é que por vezes não há muita correspondência entre as características pessoais e os comportamentos de compra.

O terceiro nível é estudo do perfil psicográfico dos clientes, que está ligado ao benefício desejado. Este tipo de estudo possibilita um melhor posicionamento para o produto e a possibilidade de se promover um marketing agressivo e direcionado. No entanto, há alguma perda de eficiência na comunicação, pois se temos informações sobre as preferências (publicações, televisão, hábitos de consumo) de uma faixa de idade, sexo ou profissão, não se tem esta informação quando se particulariza muito a característica enfocada.

O último nível trabalhado na segmentação é baseado no comportamento. Existem consumidores "volúveis", que trocam de marca porque o outro produto está em promoção ou por qualquer outro motivo, e os consumidores que são leais. $\mathrm{Na}$ prática, a segmentação baseada no comportamento pode ser difícil, mas a recompensa tende a ser grande, porque é possível maximizar a relação de troca com o cliente, evitando investimentos desnecessários em comunicação.

\section{Marketing de nicho}

A prática do marketing de nicho acontece quando uma empresa ataca um mercado-alvo apenas, tornando-se especialista no determinado nicho. Um nicho atraente apresenta algumas características: necessidades distintas, potencial de 
crescimento rápido e, em geral, não possui muitos concorrentes. Desta maneira, o marketing de nicho pode apresentar altas rentabilidades e permite uma comunicação mais direcionada que o comum.

\section{Marketing local e individual}

Mesmo empresas grandes estão se dando conta de que o foco limitado a clientes locais (áreas comerciais, bairros e até lojas) pode ser compensador. Uma cadeia de supermercados varia a disposição de seus produtos de acordo as características locais. Serviços bancários, por exemplo, são customizados para diferentes bairros. Evidentemente, há prós e contras a estas propostas. Não há interesse em se elevar demasiadamente os custos do marketing que esta estratégia pode acarretar, assim como evitar a diluição da marca, uma vez que o produto, serviço ou mensagem podem variar de lugar para lugar.

No limite desta proposta, encontra-se o marketing individual, isto é, estratégias de marketing direcionadas a um único consumidor. Interessante é que, durantes séculos, os clientes sempre foram atendidos individualmente. Após a emergência do marketing de massa, dos métodos modernos de marketing de segmentação, a proliferação de novas tecnologias, como computador, bancos de dados, celulares, produção por robôs, e-mail e fax, assiste-se hoje ao paradoxo da "customização em massa", que atende às necessidades de cada cliente sem perder as vantagens do marketing de massas.

O ramo escolar possui naturalmente algumas segmentações, que divergem por razões religiosas, de língua (no caso das bilíngües), pedagógicas, geográficas, de preços e por segmentos da grade curricular. Desta forma, sempre foi caracterizado por ser um mercado segmentado, não havendo espaço para um marketing de massa.

\subsubsection{Posicionamento e seus erros}

Posicionamento é o ato de desenvolver a oferta e a imagem da empresa, ocupando uma posição privilegiada na mente dos clientes alvo. A estratégia de 
posicionamento envolve a definição do cliente alvo, da nova vantagem a ser oferecida, da adequação dos custos ao mercado e da proposta de valor agregado.

O posicionamento tem como ponto de partida um produto, que é trabalhado para que ocorra uma modificação de percepção na mente do consumidor alvo. $O$ objetivo do posicionamento é, portanto, desenvolver características do produto que sejam vistas pelo consumidor como especiais e únicas. A partir deste posicionamento, a empresa terá mais facilidade em desenvolver a estratégia de marketing.

O primeiro passo do posicionamento é o estabelecimento das faixas de preço em que a instituição quer concorrer. Uma instituição mantendo preços muito baixos pode sofrer com escassez de recursos, e criar uma percepção de que os preços baixos equivaleriam a serviços deficientes.

Definida a questão de preços, gastos e investimentos, a estratégia de diferenciação de produtos se voltará para outros fatores, como características do produto, variáveis promocionais, estrutura do mercado e perfil das empresas concorrentes.

\section{$\underline{\text { Como diferenciar }}$}

Diferenciação é o ato de desenvolver um conjunto de diferenças significativas para distinguir a oferta da empresa da oferta da concorrência. Quando uma empresa decide-se a lutar pelo seu posicionamento, a preocupação que surge é como se diferenciar, ou quais seus pontos positivos devam ser realçados.

\section{Erros de Posicionamento}

- Subposicionamento. Pouca Idéia sobre a marca.

- Superposcionamento. A marca alcança um nível muito valorizado e afasta o comprador.

- Posicionamento confuso. Imagem não clara da marca, causada por excesso de exposição ou muitas mudanças de posicionamento. 
- Posicionamento duvidoso. É um problema de credibilidade, e pode estar ligado a característica, preço ou fabricante.

O Mapa de Posicionamento do mercado escolar na Barra da Tijuca pode ter a seguinte distribuição:

Figura 3.1. Mapa do Posicionamento

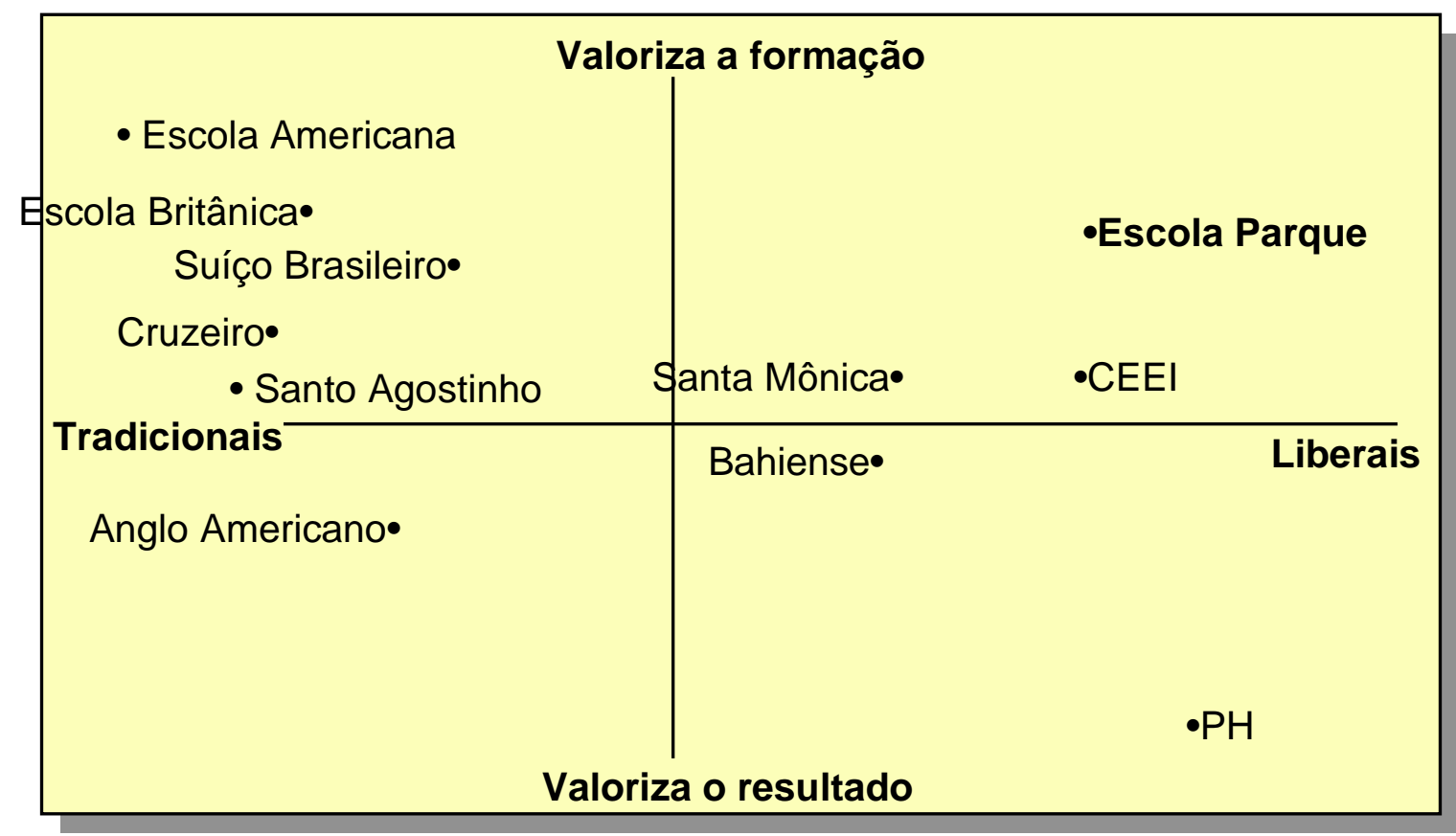

O mapa deve ser interpretado de maneira cuidadosa. Instituições que estejam localizadas como focadas na formação, não necessariamente possuem resultados ruins, e outras com foco em resultados podem não ter bons resultados. O tempo de mercado também não transforma a escola em "Tradicional", e sim seus valores e condutas.

A Escola Parque, por exemplo, está há 35 anos no mercado, mas sua imagem é liberal. Da mesma forma, o projeto pedagógico privilegia o desenvolvimento pessoal do aluno, mas os resultados no vestibular e no ENEM (Ensino Nacional do Ensino Médio) são expressivos. 


\subsubsection{Lealdade do Cliente}

Satisfação consiste na sensação de prazer ou desapontamento resultante da comparação do desempenho (ou resultado) percebido de um produto em relação às expectativas do comprador.

A influência na satisfação dos clientes segue alguns pontos que devem ser levados em consideração: produtos e serviços de qualidade, preço percebido como justo, condições de pagamento satisfatórias, cumprimento de prazos e compromissos assumidos pela empresa, disponibilidade dos produtos/serviços, entrega adequada, escuta atenciosa, diálogo de compromisso, descontos e ofertas especiais e facilidade da compra.

Conquistar a lealdade do cliente é, cada vez mais, o desafio de empresas e profissionais preocupados não só com a sua competitividade, mas com sua própria sobrevivência no mercado. O objetivo de se conquistar a lealdade dos clientes é retê-los, evitando a sua migração para a concorrência, e aumentando o valor dos negócios que eles proporcionam.

Valor entregue ao cliente é a diferença entre o valor total para o cliente e o custo total para o mesmo. O valor total é o conjunto de benefícios que os clientes esperam de um determinado produto ou serviço, esse valor é atribuído a quatro fontes: produto, serviço, pessoal e imagem. O custo total para o cliente é o conjunto de custos em que os consumidores esperam incorrer para avaliar, obter, utilizar e descartar um produto ou serviço. De um modo geral além do custo monetário, inclui os custos de tempo, de energias físicas e psíquicas do comprador.

Algumas variáveis e atributos são relevantes para que a empresa atue na retenção dos clientes:

Identificação de clientes. Captação de dados básicos dos clientes para o desenvolvimento de um banco de dados que permita a customização do atendimento; 
Diferenciação. Aplicação das regras de diferenciação para separar os clientes segundo categorias lógicas (exemplo: primeira compra, clientes eventuais, pontuais, freqüentes, fiéis, defensor, propenso etc.);

Interação. No dia-a-dia do relacionamento da organização com o cliente há uma interação que pode ser documentada, pesquisada e combinada para fazer desenvolver ações de marketing relevantes;

Customização. Todas as experiências adquiridas no relacionamento devem ser transformadas em comunicação, atendimento e ofertas personalizadas.

Lealdade está associada à comodidade. Um cliente torna-se leal porque é confortável para ele, no momento de decisão de compra. Portanto, é um mecanismo automático de decisão do cérebro. O cliente está sendo leal toda vez que, automaticamente, decide comprar aquela marca. É confortável para ele que essa decisão tenha sido tomada antes e que, neste momento, ele reserve a capacidade de analisar, criticar e decidir para aplicar em outras coisas que não na decisão sobre comprar aquela mesma marca ou a do concorrente.

A lealdade no ramo escolar basicamente se limita à continuidade dos alunos na mesma escola. $O$ índice a ser medido deve ser a taxa de saída dos alunos. $\mathrm{Na}$ Escola Parque Barra, este índice não chega a 5\%, sendo considerado pelos diretores como baixo para o mercado.

O contato com os pais é realizado, tradicionalmente, nas reuniões de pais. A Escola Parque Barra, visando a um atendimento mais individual, adotou as reuniões divididas por turma, e não por segmento ou série. Desta forma, consegue estabelecer um contato estreito com o cliente.

\subsubsection{Composto de Marketing (4 Ps)}

Quatro variáveis estratégicas são as responsáveis diretas pelo sucesso ou fracasso da empresa na busca pelos objetivos traçados: Produto, Preço, Praça e 
Promoção. São ferramentas que influem no processo de compra, em vários níveis e estágios.

Produto. É a oferta da empresa no processo de troca. Os elementos que compõe o produto podem ser: variedade, qualidade, design, nome, embalagem, tamanho, garantia e os serviços complementares agregados, como pós-venda e suporte. A cor de uma embalagem pode ser, por exemplo, fundamental para se atingir um determinado público-alvo.

Preço. É a quantidade de recursos determinada para que o processo de troca seja estabelecido. Os elementos que compõem o preço podem ser: preço de tabela, desconto, concessões, prazo de pagamento e financiamento. Prazos de pagamentos, por exemplo, têm que estar adequados com o público que se espera lidar.

Promoção. É a comunicação com o cliente. Pode ter a função informativa, de convencimento ou lembrança. Pode também preparar o cliente para uma experiência, aumentando sua satisfação ou até mesmo fazendo com que ele compreenda o serviço oferecido. Os elementos que compõem a promoção podem ser: publicidade, promoção de vendas, força de vendas, relações públicas e marketing direto.

Praça. São os canais de distribuição para que o produto chegue ao cliente ou vice-versa. A conveniência do local, fácil acesso ou não, é determinada pela estratégia adotada pelo marketing. Os elementos que podem compor a praça são: canal, cobertura, variedade, local, estoque e transporte. A marca de carro Jaguar, por exemplo, possui um, ou dois locais de venda no Rio de Janeiro. Está alinhada com seu posicionamento no mercado, com acesso exclusivo e para poucos.

O Presidente do Banco Central, por exemplo, na luta pelo controle da inflação tem algumas ferramentas ao seu alcance, como taxa de juros, emissão de papelmoeda e intervenção cambial. Da mesma forma, cabe ao profissional de marketing ajustar as variáveis disponíveis para atingir seus objetivos, como aumento de vendas, aumento da margem de contribuição, ganho de mercado etc. 
Na variável de produto, o profissional de marketing da Escola Parque Barra deve definir basicamente o número de turmas e a quantidade de alunos por sala, acompanhando sempre os objetivos estabelecidos.

Se por um lado o público atingido se dispõe a pagar um preço alto comparado ao mercado, por outro é cada vez maior o número de escolas falindo em razão da crise da classe média. Desta forma, os ajustes da matrícula devem ser cuidadosos.

A promoção no ramo escolar é uma questão delicada. Segundo os diretores da Escola Parque, a propaganda escolar não tem efeito algum ou até mesmo tem efeito negativo. De fato, educação não é um serviço que tem sua venda ligada a publicidade. Desta maneira, a assessoria de imprensa e os próprios clientes são as melhores maneiras de divulgação da marca e posicionamento.

Já a variável "Praça" é muito importante em um período pré-operacional de uma escola. O estudo do potencial da área é fundamental neste caso.

\subsubsection{Estudo de casos no Mercado Carioca (Anexo 09 e relatos)}

A reportagem da Folha de São Paulo, no dia 15 de Novembro de 2003 (Anexo 09) aponta para um quadro de crise no mercado carioca educacional. De fato, escolas tradicionais têm fechado suas portas ou reduzido o tamanho. Apesar de apresentarem diferentes fatores conjunturais, os fatores estruturais giram sempre em torno da falta de uma gestão profissional nas instituições, que não se prepararam para as mudanças de mercado.

Um tradicional colégio da Zona Sul do Rio de Janeiro, o GIMK, fechou suas portas após o falecimento da diretoria original. Explica-se: as famílias dos alunos confiavam na pessoa do diretor, e não no cargo de diretor. O processo de transição não foi trabalhado de forma clara e, então, gradualmente os clientes foram abandonando a escola, e as taxas de inadimplência aumentando. 
Já o São Marcelo, antigamente localizado na Gávea, não modernizou sua educação. Na década de 1950 e 1960, as famílias valorizavam nesta instituição seus valores religiosos, queriam garantir uma educação cristã. O colégio não acompanhou, no entanto, as mudanças do mercado, não reavaliado seu processo pedagógico. É importante ressaltar que outros colégios ligados a religião acompanharam as mudanças e estão bem posicionados no mercado atualmente.

O Colégio Bahiense, que era a continuação do São Marcelo, fechou suas portas na tradicional sede da Gávea. Apesar de manter suas atividades em outras filiais, como Campo Grande e Anil, a instituição perde suas características originais e status. O motivo é o falecimento de seu líder, Professor Bahiense. Mais uma vez um caso de confiança no líder e não na instituição.

Outro tradicional colégio, o São Patrício, fechou suas portas em 2003. A classe média entrou em crise e não conseguiu manter seus filhos na instituição, que não se modernizou e sofreu com a concorrência do mercado.

O caso da Escola Americana, no alto da Gávea, é geográfico. Mesmo com trabalhos sociais intensos e segurança reforçada, a instituição sofre com a proximidade da favela da Rocinha. Por isso, providenciou sua mudança para a Barra da Tijuca, onde começa a operar em 2007.

A sede do colégio Anglo-Americano, em Botafogo, com mais de 30 anos de mercado, fecha por problemas financeiros. O aumento da inadimplência para cerca de $20 \%$ e o aumento do aluguel do imóvel impossibilitam a continuidade das operações. Passa, então, a concentrar sua organização na sede da Barra da Tijuca, onde o imóvel é próprio.

O CEL, Centro Educacional da Lagoa, reduziu seu número de unidades. O investimento em publicidade atingiu uma grande clientela, mas o projeto pedagógico não suportou. A imagem do colégio era uma, mas na prática outra.

A Chave do Tamanho, apoiada na figura do seu líder, Lauro de Oliveira Lima, reduziu sua operação também. Na década de 1970, estava posicionada como uma 
escola de vanguarda, com pensamentos novos e modernos. No entanto, isolou-se da realidade, mantendo sua linha pedagógica independente das mudanças do mundo. Soma-se a falta de definição da sua imagem junto ao público, que não entendia claramente a proposta pedagógica.

\subsection{Conceitos de estratégia}

\subsubsection{Planejamento estratégico}

O marketing, para alcançar na prática sua utilidade, precisa de planejamento, definindo metas e a maneira de atingi-las. O planejamento de uma empresa se manifesta de três formas:

Planejamento Operacional. Objetivos e metas criadas para unidades operacionais individuais no curto prazo. Acontece em tarefas cotidianas.

Planejamento Tático. Objetivos e metas criadas para departamento ou divisão específica para o médio prazo (um a cinco anos). Geralmente os gerentes são os responsáveis.

Planejamento Estratégico. Objetivos e metas criadas para empresa toda para o longo prazo. Define o perfil da empresa e de que maneira este perfil vai se manifestar para que os objetivos sejam alcançados.

O ponto de início para se definir o perfil da empresa envolve uma análise ampla, porém não superficial, da sua Missão, Visão e Valores. Estes itens estarão presentes em todas as decisões da empresa, seja qual for o nível em questão. A "Missão" é a razão de ser da empresa e deve ser entendida de maneira clara por todos. A missão de uma empresa no ramo do cinema, por exemplo, provavelmente deve ser ligada ao entretenimento e não à produção de filmes. Seus concorrentes, portanto, não são somente outras produtoras de filmes, mas também a televisão, parque de diversões ou até mesmo bares e boates. 
A Visão de uma empresa é a imagem que ela projeta de si mesma para o futuro, como resultados e imagem. Estabelecer uma visão real é fundamental para que o planejamento estratégico obtenha sucesso. A visão não projeta necessariamente a empresa para atingir o primeiro lugar no mercado em que está inserida. A companhia de petróleo Ipiranga não pretende, por exemplo, competir com a Petrobrás. Seus objetivos são traçados para que mantenha a segunda posição no mercado nacional.

Valores são preceitos internos à empresa, que norteiam o modo de agir e de tomar decisões em todas as ações. É a manifestação dos ideais e da ética adotada pela empresa, e funciona como base de regras de conduta e convivência de todos.

Nas escolas é difícil encontrar uma visão estratégica apurada do mercado pelos diretores. O crescimento da concorrência e a crise no ramo, no entanto, expuseram muitas fraquezas das escolas, e o planejamento estratégico ganhou importância relevante. A Escola Parque, por exemplo, somente foi definir com clareza sua missão, valores e objetivos há quatro anos.

\subsubsection{Análise do ambiente externo (Porter)}

Diversos fatores exógenos às empresas podem ter influência direta ou indireta no seu desempenho. O desenvolvimento da estratégia de marketing tem, necessariamente, que levar em conta estas variáveis. Características e mudanças nos ambientes econômico, político e legal, social, natural, tecnológico e competitivo precisam ser avaliados e conhecidos.

Ambiente Econômico. A economia do país e regiões influencia a demanda pelos produtos e serviços. Ciclo de negócios (que podem passar por momento de prosperidade, recessão ou recuperação), a renda do consumidor e os padrões de consumo são os principais componentes do ambiente econômico. O Anexo 09 identifica como uma das causas da crise das escolas no mercado do Rio de janeiro a perda de poder aquisitivo da classe média. 
Ambiente Político e Legal. Este ambiente é, basicamente, determinado pelas leis, regulamentações e pressões políticas. A corrupção, com favorecimentos e privilégios, também é uma variável externa que influencia o desempenho das empresas. Há cerca de sete anos o Governo editou uma medida que facilitava a inadimplência escolar ao proibir o cancelamento de matrícula por falta de pagamento.

Ambiente Social. Tendências demográficas e globais, diversidade populacional e Responsabilidade social e ética são elementos muito importantes no estudo do mercado. Talvez o exemplo mais claro seja na internacionalização de uma empresa, quando a adequação dos produtos à sociedade é ponto de partida. $O$ constante crescimento da Barra da Tijuca foi ponto predominante para enxergar a oportunidade de negócio na abertura da filial.

Ambiente Natural. A relação com a natureza tem que ser levada em consideração também. Devem-se analisar os recursos naturais disponíveis e a forma que eles afetam a organização. O projeto pedagógico da Escola Parque Barra necessariamente envolve a interação do aluno com a natureza.

Ambiente Tecnológico. Avanços, tendências, tecnologia disponível, pesquisas, inovações. Todos estes elementos ligados à tecnologia incidem no dia-adia da empresa, pois são maneiras de criação de valor para os clientes. O setor de educação talvez seja um dos maiores beneficiados pelos avanços tecnológicos, principalmente na área de informática, em que o fluxo livre de informações pela Internet é cada vez mais uma realidade.

Ambiente Competitivo (Modelo de Porter). É formado por todas as organizações que criam valor para um mercado ou tem potencial para isso. São as chamadas "Cinco Forças Competitivas":

Rivalidade entre concorrentes existentes - Conhecer as empresas concorrentes e suas estratégias é fundamental para o desenvolvimento das suas próprias ferramentas de marketing. 
Ameaça de novos ingressantes - O desempenho ruim, altos lucros e excesso de demanda podem encorajar novos concorrentes no mercado. A questão avaliada é o grau de dificuldade das barreiras de entrada. O mercado da Barra da Tijuca vem assistindo à abertura de novas escolas. Em geral, são filiais de escolas de prestígio.

Ameaça de produtos substitutos - É importante que o profissional de marketing localize no mercado todos os produtos que podem rivalizar com o seu. Não necessariamente o rival é um produto similar, podendo ser um outro que tenha o mesmo propósito. Um automóvel, por exemplo, pode ter sua compra adiada ou cancelada por uma viagem ao exterior. No ramo escolar, dificilmente há um produto substituto. Escolas técnicas, tutorias e ensino a distância são possíveis substitutos ao ensino escolar presencial tradicional.

Poder de barganha dos fornecedores - Contar com poucos fornecedores pode ser perigoso. Além de perder espaço na negociação, com preços e prazos ruins, corre-se o risco de estrangulamento do fornecimento em caso de falências. Desta maneira, a cooperação entre fornecedor e empresa é fundamental. Esta força não incide muito no ramo escolar, pois as matérias-primas utilizadas são encontradas em diversos estabelecimentos.

Poder de barganha dos compradores - Esta força aplica-se, basicamente, a grandes compradores, que por serem responsáveis por significativa parcela do faturamento das empresas, podem determinar preços, prazos e modo de produção. No caso da Barra da Tijuca, os grandes compradores seriam as associações de moradores e condomínios que podem pressionar por reduções de preços ou mudanças em algum procedimento.

\subsubsection{Análise SWOT}

Os profissionais de marketing, ao escolherem as estratégias a serem adotadas pela empresa, têm que analisar os ambientes interno e externo conjuntamente. O levantamento dos pontos fortes e fracos da empresa, assim como as oportunidades e ameaças do ambiente externo são o ponto de partida para a 
definição de estratégias. A combinação entre estes dados pode determinar a atuação em determinado mercado ou não. Em inglês, é conhecida por "SWOT", sendo a denominação mais comum adotada pelo mercado brasileiro.

\begin{tabular}{|ll|}
\hline \multicolumn{2}{|c|}{ Ambiente Interno } \\
\hline $\begin{array}{l}\text { Forças } \\
\begin{array}{l}\text { Marcas bem conhecidas } \\
\text { Habilidades tecnológicas }\end{array}\end{array}$ & $\begin{array}{l}\text { Falta de direção estratégica } \\
\text { Altos custos } \\
\text { Instalações Obsoletas }\end{array}$ \\
\hline \multicolumn{1}{|c|}{ Ambiente Externo } \\
\hline $\begin{array}{l}\text { Oportunidades } \\
\begin{array}{l}\text { Novos mercados potenciais produtos potenciais } \\
\text { Queda de barreiras comerciais } \\
\text { internacionais }\end{array}\end{array}$ & Ameaças \\
\hline & $\begin{array}{l}\text { Nova concorrência } \\
\text { Crescimento lento do mercado } \\
\text { Novas regulamentações }\end{array}$ \\
\hline
\end{tabular}

Churchill, Gilb. Criando valor para o cliente.

Forças e deficiências. Analisar os pontos fortes e fracos de uma empresa é fundamental para se traçar estratégias. A dificuldade é enxergar claramente quais as competências básicas que a empresa têm melhor que as demais, e quais as deficiências apresentadas que não sejam comuns a todo restante do mercado. Se, por exemplo, uma empresa consegue se adaptar rapidamente a mudanças na legislação e outros concorrentes não, pode-se considerar a flexibilidade como um ponto forte da empresa. As deficiências podem ser diversas e influenciar em vários níveis. Deve-se avaliar, inclusive, como superá-las.

Oportunidades e ameaças. O ambiente externo está em processo contínuo de constantes mutações. Desta maneira, novos mercados são abertos, novos produtos demandados e novas necessidades criadas, apontando novas oportunidades de negócios. Da mesma forma, novas empresas são abertas, novos produtos ofertados e necessidades saciadas, constituindo ameaças para os negócios.

O papel do profissional de marketing é combinar todas as variáveis apresentadas (pontos fortes e fracos, oportunidades e ameaças) e definir as 
estratégias de atuação. Pontos fortes com oportunidades têm potencial enorme de sucesso e pontos fracos e ameaças, provavelmente, indicam um fracasso nos negócios.

Alguns pontos do ambiente interno e externo são mais recorrentes na análise Swot para empresas do ramo escolar:

\begin{tabular}{|c|c|}
\hline \multicolumn{2}{|c|}{ Ambiente Interno } \\
\hline Forças & Deficiências \\
\hline $\begin{array}{l}\text { Pessoal da linha de frente } \\
\text { Localização } \\
\text { Tradição } \\
\text { Posicionamento } \\
\text { Projeto pedagógico bem aceito }\end{array}$ & $\begin{array}{l}\text { Administração obsoleta } \\
\text { Localização } \\
\text { Defasagem pedagógica e tecnológica } \\
\text { Imagem distorcida } \\
\text { Fatos isolados ("escândalos") } \\
\text { Inadimplência alta }\end{array}$ \\
\hline \multicolumn{2}{|c|}{ Ambiente Externo } \\
\hline $\begin{array}{l}\text { Fragilidade de concorrentes } \\
\text { Novos bairros crescendo } \\
\text { Competição por empregos } \\
\text { Decadência da rede pública }\end{array}$ & $\begin{array}{l}\text { Melhora da rede pública } \\
\text { Grandes redes escolares } \\
\text { Crise econômica } \\
\text { Novas regulamentações }\end{array}$ \\
\hline
\end{tabular}

A análise de Swot da Escola Parque Barra está contemplada no item 4.18.

\subsubsection{Matriz de crescimento / participação}

Identificar o potencial dos produtos no mercado é fundamental para desenvolver uma estratégia vencedora. A alocação de recursos deve levar em conta o crescimento do mercado e a participação da empresa no mesmo. O grupo Boston Consulting Group criou a "Matriz BCG", que facilita a classificação dos produtos no mercado. 
Figura 3.2.

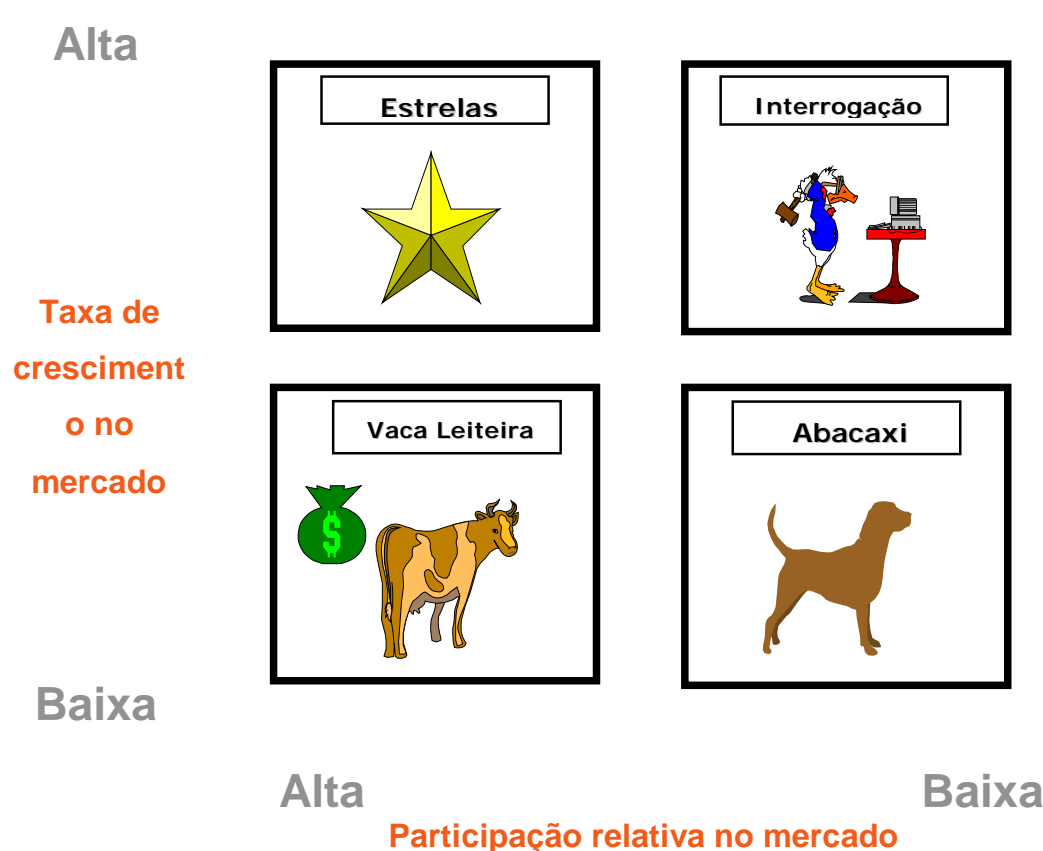

Estrelas. Possuem alta fatia do mercado que cresce aceleradamente. $O$ grande problema é que estes mercados, por serem muito atraentes, demandam muitos gastos para que se proteja a participação. O centro de atividades, que oferece diversos cursos e aulas fora do horário pode ser apontado como um produto estrela da Escola Parque Barra. Como é alto o percentual de alunos de famílias "novas" no bairro, a procura por cursos como inglês, futebol e teatro, por exemplo, é alta na Escola. Os clubes, cursos de idiomas e similares são concorrentes especializados nestes serviços, o que obriga a prática de uma margem de lucro reduzida.

Vacas leiteiras. Participação alta em um mercado de crescimento baixo. Sem muita concorrência, a lucratividade é alta, e transforma a empresa dependente financeiramente dele. No caso da empresa, a "Vaca leiteira" é a grade curricular oferecida, com mensalidades praticadas com preços definitivos. A cantina também pode ser apontada como uma "Vaca Leiteira" já que é a única venda em alimentação. 
Abacaxis. Baixa participação em mercado de baixo crescimento. Geralmente são descartados pelas empresas ou terceirizados em alguns casos. Com o crescimento da oferta de transportes alternativos como Vans e ônibus de condomínios, os ônibus contratados pela Escola podem ser considerados "Abacaxis". Possuem baixa participação e o mercado diminui cada vez mais com serviços substitutos.

Interrogação. Baixa participação em um mercado de crescimento alto. Deve analisar o potencial de longo prazo do produto e avaliar a necessidade de investimento para obter fatias de mercado. Apesar de não oferecer o serviço de ensino a distância, é o produto que mais se aproxima de um "Ponto de Interrogação". É um mercado que cresce muito e a Escola Parque Barra não oferece esta opção.

\subsubsection{CVA (Customer Value Analysis)}

O desenvolvimento do mercado provoca, cada vez mais, o aumento da competição entre as empresas, transformando a busca e a manutenção do sucesso em um objetivo alcançado não só pela qualidade, tecnologia e diferenciação, mas também pela percepção do cliente.

Desta forma, as empresas devem entender qual a diferença entre o que produz e vende e o que o cliente compra. O desafio é, portanto, orientar a empresa para o cliente para que entenda as suas necessidades e seus desejos. A comparação de percepção é feita com os competidores do setor, concluindo então onde se leva vantagem e desvantagens.

Uma forma de se fazer esta medição é o Customer Value Analysis (CVA), que identifica o que a qualidade e o preço realmente significam para os clientes, atribuindo uma nota comparativa a diversos itens. Desta forma, chega-se a um índice do mercado, formado pelos principais competidores e o índice da empresa analisada. O CVA é uma forma simples e pouco onerosa para se medir a competitividade da empresa. 


\section{Abaixo o CVA da Escola Parque Barra:}

\section{Tabela 3.1. Atributos da Qualidade}

\begin{tabular}{|c|c|c|c|c|c|c|c|c|c|c|c|c|c|c|}
\hline \multicolumn{2}{|r|}{ Atributo de Qualidade } & \multirow[t]{2}{*}{ PESO } & \multicolumn{2}{|c|}{ EP Barra } & \multicolumn{2}{|c|}{$\begin{array}{c}\text { Sto. } \\
\text { Agostinho }\end{array}$} & \multicolumn{2}{|c|}{ Cruzeiro } & \multicolumn{2}{|c|}{$\mathrm{PH}$} & \multicolumn{2}{|c|}{ CEEI } & \multirow[t]{2}{*}{ Média } & \multirow[t]{2}{*}{ ÍNDICE } \\
\hline & & & Nota & Indice & Nota & Indice & Nota & Indice & Nota & Indice & Nota & Indice & & \\
\hline 1 & Nivel de ensino na prática igual ao oferecido & $14 \%$ & 4 & 0,56 & 5 & 0,7 & 5 & 0,7 & 5 & 0,7 & 3 & 0,42 & 0,63 & 0,89 \\
\hline 2 & Contribuição positiva na formação do aluno & $13 \%$ & 5 & 0,65 & 5 & 0,65 & 4 & 0,52 & 2 & 0,26 & 4 & 0,52 & 0,49 & 1,33 \\
\hline 3 & Projeto pedagógico claro & $12 \%$ & 3 & 0,36 & 5 & 0,6 & 4 & 0,48 & 4 & 0,48 & 3 & 0,36 & 0,48 & 0,75 \\
\hline 4 & Bons professores & $11 \%$ & 5 & 0,55 & 4 & 0,44 & 4 & 0,44 & 5 & 0,55 & 5 & 0,55 & 0,50 & 1,11 \\
\hline 5 & Atualizada pedagogicamente & $10 \%$ & 5 & 0,5 & 5 & 0,5 & 4 & 0,4 & 4 & 0,4 & 4 & 0,4 & 0,43 & 1,18 \\
\hline 6 & Bons resultados & $10 \%$ & 3 & 0,3 & 5 & 0,5 & 5 & 0,5 & 5 & 0,5 & 3 & 0,3 & 0,45 & 0,67 \\
\hline 7 & Disponibilidade em atender os pais & $10 \%$ & 5 & 0,5 & 4 & 0,4 & 3 & 0,3 & 4 & 0,4 & 5 & 0,5 & 0,40 & 1,25 \\
\hline 8 & Aplicação prática da informática & $8 \%$ & 3 & 0,24 & 4 & 0,32 & 3 & 0,24 & 4 & 0,32 & 3 & 0,24 & 0,28 & 0,86 \\
\hline 9 & Disciplinador sem rigidez excessiva & $7 \%$ & 3 & 0,21 & 4 & 0,28 & 3 & 0,21 & 3 & 0,21 & 3 & 0,21 & 0,23 & 0,92 \\
\hline & Portfólio diversificado de atividades extras & $5 \%$ & 5 & 0,25 & 3 & 0,15 & 5 & 0,25 & 2 & 0,1 & 2 & 0,1 & 0,15 & 1,67 \\
\hline & TOTAL DE PONTOS & $100 \%$ & & 12 & & 54 & 4, & 04 & & 92 & & 60 & 4,03 & 1,06 \\
\hline
\end{tabular}

Tabela 3.2. Atributos de Preço

\begin{tabular}{|c|c|c|c|c|c|c|c|c|}
\hline \multirow[t]{2}{*}{ Atributo de Preço } & \multirow[t]{2}{*}{ PESO } & EP Barra & $\begin{array}{c}\text { Sto. } \\
\text { Agostinho }\end{array}$ & Cruzeiro & $\mathrm{PH}$ & CEEI & \multirow[t]{2}{*}{ Média } & \multirow[t]{2}{*}{ ÍNDICE } \\
\hline & & Nota Índice & Nota Índice & Nota Índice & Nota Índice & Nota Índice & & \\
\hline 1 Bom custo-beneficio & $70 \%$ & 2,8 & 3,5 & 2,8 & 2,8 & 2,8 & 2,975 & 0,94 \\
\hline 2 Taxa de inadimplência baixa & $30 \%$ & 1,5 & 1,2 & 1,2 & 1,2 & 0,9 & 1,125 & 1,33 \\
\hline TOTAL DE PONTOS & $100 \%$ & 4,3 & 4,7 & 4 & 4 & 3,7 & 4,1 & 1,14 \\
\hline
\end{tabular}

\section{Tabela 3.3. Atributos Estruturais}

\begin{tabular}{|c|c|c|c|c|c|c|c|c|c|c|c|c|c|}
\hline \multirow[t]{2}{*}{ Atributo Estrutural } & \multirow[t]{2}{*}{ PESO } & \multicolumn{2}{|c|}{ EP Barra } & \multicolumn{2}{|c|}{$\begin{array}{c}\text { Sto. } \\
\text { Agostinho }\end{array}$} & \multicolumn{2}{|c|}{ Cruzeiro } & \multicolumn{2}{|c|}{$\mathrm{PH}$} & \multicolumn{2}{|c|}{ CEEI } & \multirow[t]{2}{*}{ Média } & \multirow[t]{2}{*}{ ÍNDICE } \\
\hline & & Nota & Indice & Nota & Indice & Nota & Indice & Nota & Indice & Nota & Indice & & \\
\hline 1 Equipamentos de informática avançados & $31 \%$ & 3 & 0,93 & 3 & 0,93 & 4 & 1,24 & 4 & 1,24 & 3 & 0,93 & 1,085 & 0,86 \\
\hline 2 Fácil acesso & $25 \%$ & 3 & 0,75 & 5 & 1,25 & 2 & 0,5 & 4 & 1 & 4 & 1 & 0,9375 & 0,80 \\
\hline 3 Boas instalações para esporte e lazer & $25 \%$ & 2 & 0,5 & 3 & 0,75 & 5 & 1,25 & 2 & 0,5 & 2 & 0,5 & 0,75 & 0,67 \\
\hline 4 Laboratório de ciências avançado & $19 \%$ & 3 & 0,57 & 3 & 0,57 & 4 & 0,76 & 3 & 0,57 & 2 & 0,38 & 0,57 & 1,00 \\
\hline TOTAL DE PONTOS & $100 \%$ & & 75 & & ,5 & &, 75 & & 31 & & 81 & 3,3425 & 0,83 \\
\hline
\end{tabular}




\section{Tabela 3.4. Pontuação Final}

\begin{tabular}{|c|c|c|c|c|c|c|c|c|c|c|c|}
\hline \multirow{2}{*}{ Pontuação Final } & \multirow{2}{*}{ PESO } & \multicolumn{2}{|c|}{ EP Barra } & \multicolumn{2}{|c|}{$\begin{array}{c}\text { Sto. } \\
\text { Agostinho }\end{array}$} & \multicolumn{2}{|c|}{ Cruzeiro } & \multicolumn{2}{|c|}{$\mathrm{PH}$} & \multicolumn{2}{|c|}{ CEEI } \\
\hline & & Indice & Ajuste & Indice & Ajuste & Indice & Ajuste & Indice & Ajuste & Indice & Ajuste \\
\hline 1 Atributo de Qualidade & $50 \%$ & 4,12 & 2,06 & 4,54 & 2,27 & 4,04 & 2,02 & 3,92 & 1,96 & 3,60 & 1,8 \\
\hline 2 Atributo de Preço & $25 \%$ & 4,3 & 1,075 & 4,7 & 1,175 & 4 & 1 & 4 & 1 & 3,7 & 0,925 \\
\hline 3 Atributo Estrutural & $25 \%$ & 2,75 & 0,688 & 3,5 & 0,875 & 3,75 & 0,938 & 3,31 & 0,8275 & 2,81 & 0,703 \\
\hline TOTAL DE PONTOS & $100 \%$ & 3,8 & 225 & 4, & 32 & & 575 & 3,7 & 375 & 3,4 & 275 \\
\hline
\end{tabular}

A análise CVA da Escola Parque Barra levanta alguns pontos a serem discutidos. Nos atributos de qualidade, a pontuação de 1,06 indica que está praticamente na média dos principais concorrentes. Destaques positivos para "Contribuição positiva na formação do aluno" e "Disponibilidade em atender os pais". Estes atributos são diferenciais competitivos para a empresa e devem ter continuidade no desenvolvimento. Já os destaques negativos foram os atributos "Projeto pedagógico claro" e "Bons resultados". Apesar de a pesquisa de mercado (item 2.2.) ter revelado que um grande percentual de pais saberia explicar o projeto pedagógico da Escola Parque Barra, os diretores entendem que a falta de clareza é um dos grandes problemas da empresa. A baixa pontuação em "Bons resultados" está ligada ao fato de ainda não ter nenhuma turma formada no ensino médio, e por conseqüência não ter resultados no vestibular e no ENEM (Anexo 13).

Nos atributos de preço, a Escola Parque Barra está acima do mercado. Apesar de possuir uma mensalidade alta, é considerada um bom investimento. A taxa de inadimplência é uma das menores do mercado segundo os diretores.

Nos atributos estruturais a empresa encontra seu maior problema. A pontuação de 0,83 indica que está muito abaixo do mercado competitivo. Sua localização, perto do Recreio dos Bandeirantes, ainda é considerada longe. As instalações esportivas e de lazer estão em fase de construção o que justifica a nota baixa. Os equipamentos de informática não são percebidos como um ponto forte na Escola Parque Barra, apesar de ter feito investimentos na área, o que acena para possibilidade de falta de aplicação prática das ferramentas de informática. 
Na pontuação final, a empresa aparece na terceira posição, a frente do CEEI e praticamente empatado com o colégio PH. A diferença para Santo Agostinho e Cruzeiro não é tão grande, e a tendência é diminuir com a finalização das obras de expansão e inauguração das séries restantes.

\subsubsection{Estratégias genéricas}

Estratégias genéricas são modos simplistas de adoção de estratégias. Antes de detalhar e desenvolver uma estratégia específica para o negócio, escolhe-se um caminho básico a seguir entre Crescimento, Manutenção, Aproveitamento máximo e Abandono.

Crescimento. Aumentar a participação de mercado, inclusive com preços abaixo do custo.

Manutenção. Preservar a participação de mercado. Empresas com fluxo de caixa estável e seguro no médio prazo pelo menos.

Aproveitamento Máximo. É utilizada para produtos sem grandes perspectivas futuras, como "Abacaxi" e "Interrogação". Neste caso, a empresa quer retorno no curto prazo sem a preocupação do longo prazo.

Abandono. Vender ou encerrar o negócio e usar os resultados em outra atividade mais rentável.

A Escola Parque Barra está em processo de expansão da sua infra-estrutura, adotando, portanto, uma estratégia genérica de crescimento.

\subsubsection{Estratégias de crescimento}

Empresas têm quatro estratégias básicas para alcançar um objetivo de crescimento: Penetração no mercado, Desenvolvimento do mercado, 
Desenvolvimento de produtos e Diversificação. Estas estratégias foram extraídas da matriz produto/mercado.

Figura 3.3.

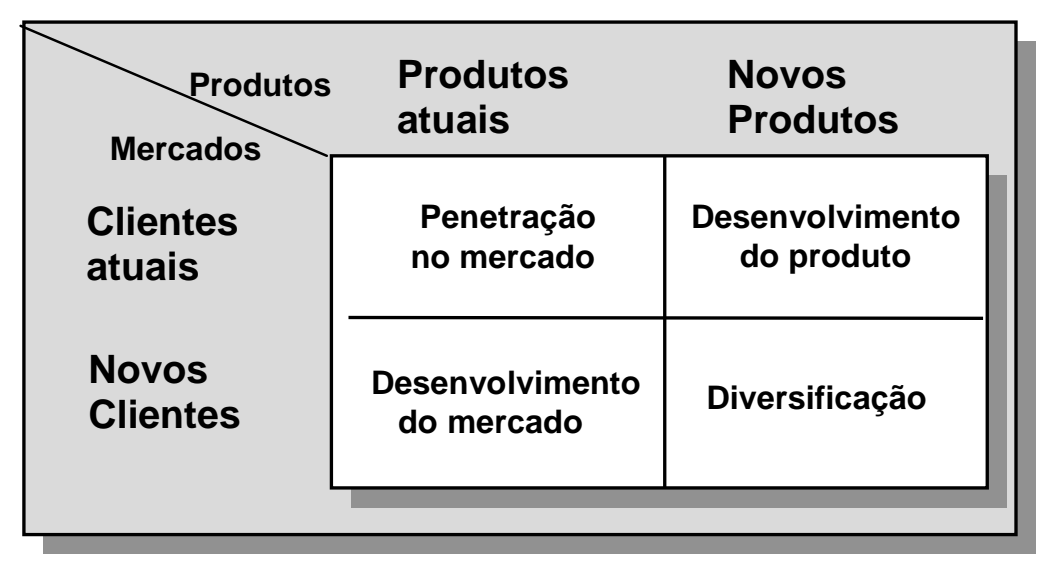

Churchill, Gilb. Criando valor para o cliente.

Penetração no mercado. Incentivar os clientes atuais a adquirirem mais dos produtos já oferecidos. É o caso do aumento das vendas do centro de atividades, que acontece fora do horário regular das aulas.

Desenvolvimento do mercado. Aquisição dos produtos já oferecidos por novos clientes. É a estratégia a ser usada pela Escola Parque Barra no seu processo de expansão, justamente ofertando sua Grade Curricular a novos clientes.

Desenvolvimento de produtos. Novos produtos para os clientes atuais. Novos cursos no centro de atividades ou projetos de intercâmbio se enquadram nesta estratégia de crescimento.

Diversificação. Novos produtos para novos clientes. É uma opção interessante de crescimento, onde devem se avaliar as possibilidades de investimento e as vantagens competitivas da empresa. A Escola Parque Barra, por exemplo, não oferece ensino a distância. Mas pode concluir que possui conhecimento suficiente para ofertar com qualidade este serviço. 


\subsubsection{Estratégias de liderança (Porter)}

Ao adotar estratégias competitivas de posicionamento competitivo, a empresa escolhe alguns caminhos. Michael Porter sugere três maneiras de se alcançar uma estratégia vencedora:

Liderança de custos. Maneira mais objetiva de posicionamento estratégico. Basicamente, resume-se a ofertar preços baixos e garantir uma grande fatia de mercado.

Diferenciação. Este tipo de estratégia caracteriza-se pela singularidade dos produtos desejados pelos clientes. A manifestação de atributos valorizados pelos clientes é específica para cada negócio. Em geral, os clientes preferem este tipo de marca, dependendo, no entanto, do preço cobrado.

Foco. É selecionada uma área ou conjunto de áreas dentro da empresa para concentrar esforços. O produto ofertado é tão especifico, que a empresa consegue vantagens competitivas em tecnologia e custos. Um caso clássico é o produtor de zíperes, que ao focar em uma parte especifica de roupas, atingiu liderança mundial.

É possível que a combinação das estratégias acima alcance sucesso no mundo dos negócios, mas, em geral, as empresas bem sucedidas adotam somente uma. Algumas empresas, ao tentarem utilizar mais que uma estratégia de posicionamento, podem acabar não sendo boas em nenhuma delas, não alcançando destaque algum.

A Escola Parque Barra adota a estratégia de liderança por diferenciação, pois é umas das únicas escolas com qualidade percebida pelo mercado, não religiosa e não bilíngüe, com uma proposta pedagógica não tradicional. 


\section{CAPÍTULO IV - PLANO ESTRATÉGICO DE MARKETING}

\subsection{Sumário Executivo}

\section{Valores}

A Escola Parque tem como seus valores básicos sua responsabilidade social e compreende o aluno como um agente de sua própria formação.

\section{Visão}

Em sua visão estratégica, apresenta-se como escola de escolha para as classes $A$ e $B$, não bilíngüe e laica.

Missão

Considera ser sua missão, a formação de jovens, não apenas nos aspectos de aquisição de habilidades específicas, que provem dos conhecimentos decorrentes dos currículos escolares, mas principalmente fornecendo a estes jovens ferramentas que proporcionem instrumentos de reflexão e estimulem a consciência social.

\section{Descrição da empresa}

A Escola Parque tem sua sede administrativa situada na Gávea, e outra unidade inaugurada há cinco anos na Barra da Tijuca. Esta unidade é o alvo do nosso objeto de estudo.

\section{Estágio de desenvolvimento}

A Escola Parque Barra ainda está em fase de implementação, inclusive no que concerne sua estrutura física.

\section{Estrutura organizacional}

Os acionistas da Escola Parque Barra são constituídos pela Escola Parque Gávea e um sócio financeiro e as decisões são tomadas por um Conselho administrativo e pedagógico. O dia a dia da Escola fica a cargo de Coordenadorias, em cada segmento curricular, sob a orientação direta da unidade da Gávea. 


\section{Serviços}

O serviço principal da Escola Parque Barra corresponde a toda grade curricular do ensino básico.

\section{Mercado de atuação}

A empresa atua nos bairros da Barra da Tijuca e Recreio dos Bandeirantes, como uma opção não bilíngüe e laica.

\section{Concorrentes}

Os principais concorrentes da Escola Parque Barra são o Santo Agostinho, Cruzeiro, Colégio PH e CEEl.

\section{Diferenciação sobre a concorrência}

O projeto pedagógico, a variável preço, a tradição da instituição, os indicadores de sucesso, a filosofia que estimula a autonomia do aluno, o espaço físico e o mix de serviços complementares são elementos que diferenciam a empresa no mercado.

\section{Operações}

A Escola Parque Barra tem uma estrutura mais simplificada do que a matriz na Gávea, compartilhando itens estruturais e burocráticos.

\section{Capacidades e Limitações}

A ocupação física da área, conforme a previsão da diretoria da Escola Parque, é a máxima permitida pela legislação. O maior entrave é o curto tempo disponível para as construções, cerca de 40 dias por ano.

\section{Estilo de administração e clima organizacional}

A estrutura de gestão da Escola Parque Barra é compartilhada entre os sócios diretores e se articula com uma equipe responsável pela implementação das decisões. Os sócios diretores são assessorados por profissionais de diversas áreas. 
Orientação para o Marketing.

Análise da imagem corporativa, a inteligência de marketing e pesquisas, 0 atendimento ao cliente, a força de vendas, a comunicação e propaganda, a definição do público cliente e a ocorrência das inovações.

\section{Comportamento ambiental e a responsabilidade social}

A Escola Parque Barra prevê projetos como o Vestibular Comunitário, as aulas de apoio a comunidade, a alfabetização de adultos e o projeto de Horta orgânica.

Resumo do desempenho da unidade da Barra da Tijuca

Os números apresentados comprovam o bom desempenho da unidade.

\section{Análise de SWOT Escola Parque Barra}

Após análises como o "CVA", o "Mapa de Posicionamento", "Estratégias Genéricas e de Liderança" e "as Cinco forças competitivas", e levantar os dados primários e secundários relevantes à empresa, foram definidos os pontos fortes e fracos do ambiente interno, e as oportunidades e ameaças do ambiente externo.

\section{Fatores Críticos de Sucesso}

Proposta pedagógica e disciplinar clara e atualizada, garantia de viabilidade e implementação das decisões estratégicas, organização dos processos vitais, a atenção e preocupação contínua com o aluno e a manutenção de estrutura física de qualidade são os fatores críticos de sucesso apontados pelo estudo.

\section{Cadeia de valores Escola Parque Barra}

Desenvolveremos a cadeia de valores da Empresa, destacando os atributos que influenciam os pontos estratégicos da Escola Parque Barra.

\section{Estratégia no nível de negócios}

A estratégia adotada pela Escola Parque Barra é o "Desenvolvimento do mercado", ou seja, a aquisição dos produtos já oferecidos por novos clientes. 


\section{Objetivos e Estratégias de marketing}

Conhecendo-se os objetivos de marketing podem-se sugerir as estratégias de marketing, e assim definir através de uma matriz de aderência, quais os caminhos a serem seguidos.

\subsection{Valores}

A Escola Parque Barra foi fundada por educadores que entendem o importante papel de responsabilidade social que assumem ao dirigirem uma instituição de ensino. O aluno é visto como um ser humano em formação, capaz de construir seus próprios conhecimentos e futuro protagonista da sociedade, e não como uma fonte geradora de riqueza.

\subsection{Visão}

A empresa pretende ser referência de vanguarda em educação e primeira opção nos bairros da Barra da Tijuca e Recreio dos Bandeirantes para famílias de classes A e B entre as escolas não-bilíngues e laicas. Pretende ser uma instituição que dissemine a filosofia de educação adotada. $\mathrm{O}$ anexo 10 apresenta a descrição da filosofia adotada.

\subsection{Missão}

A Escola Parque tem como Missão formar jovens capacitados a enfrentar, conscientemente, o mundo atual e futuro. Mais do que lecionar, a empresa é uma facilitadora no aprendizado, fornecendo ferramentas, como cultura e educação, que permitam o desenvolvimento natural do adolescente. A escola também prepara o jovem para contribuir com o enriquecimento da cultura humana, estimulando nos alunos uma mentalidade planetária, além de suas individualidades. 


\subsection{Descrição da empresa}

A razão social da empresa é Sociedade Educadora de Vanguarda, tendo como nome fantasia "Escola Parque". Há 35 anos atua no setor de serviços, na área educacional. A sede administrativa é no bairro da Gávea, no município do Rio de Janeiro. Há cinco anos começou sua operação com a unidade da Barra da Tijuca, alvo do presente estudo. A empresa não possui capital aberto e é tributada pelo modelo de "lucro presumido".

\subsection{Estágio de desenvolvimento}

A sede administrativa da empresa, na Gávea, foi fundada há 35 anos e já está estabelecida e reconhecida no mercado. A Escola Parque Barra possui cinco anos de mercado e ainda está em fase de implantação progressiva. As próprias instalações físicas ainda não foram finalizadas, faltando incorporar as $7^{\circ}$ e $8^{\circ}$ séries do Ensino Fundamental II e o $3^{\circ}$ ano do Ensino Médio na grade curricular. O Anexo 11 apresenta a divisão do Ensino Básico determinado pelo MEC (Ministério de Educação e Cultura). Como relatado na Formulação do Problema (item 1.2), os diretores já tomaram a decisão relativa ao crescimento. O quadro 4.1, a seguir, apresenta o plano de desenvolvimento referente ao número de turmas.

\section{Quadro 4.1. Projeção número de turmas Escola Parque Barra}

\begin{tabular}{|c|c|c|c|c|c|c|c|}
\hline Segmentos & $\mathbf{2 0 0 5}$ & $\mathbf{2 0 0 6}$ & $\mathbf{2 0 0 7}$ & $\mathbf{2 0 0 8}$ & $\mathbf{2 0 0 9}$ & $\mathbf{2 0 1 0}$ & $\mathbf{2 0 1 1}$ \\
\hline Ed. Infantil & 12 & 12 & 12 & 12 & 12 & 12 & 12 \\
\hline Ens. Fund. I & 06 & 09 & 11 & 13 & 16 & 16 & 16 \\
\hline Ens. Fund. II & 01 & 03 & 07 & 09 & 13 & 15 & 16 \\
\hline Ens. Médio & 01 & 02 & 03 & 05 & 08 & 11 & 12 \\
\hline
\end{tabular}


De acordo com o crescimento vertical previsto, a Escola Parque Barra completa sua grade curricular no começo de 2008 e $100 \%$ de sua capacidade possível e instalada em 2011.

\subsection{Estrutura organizacional}

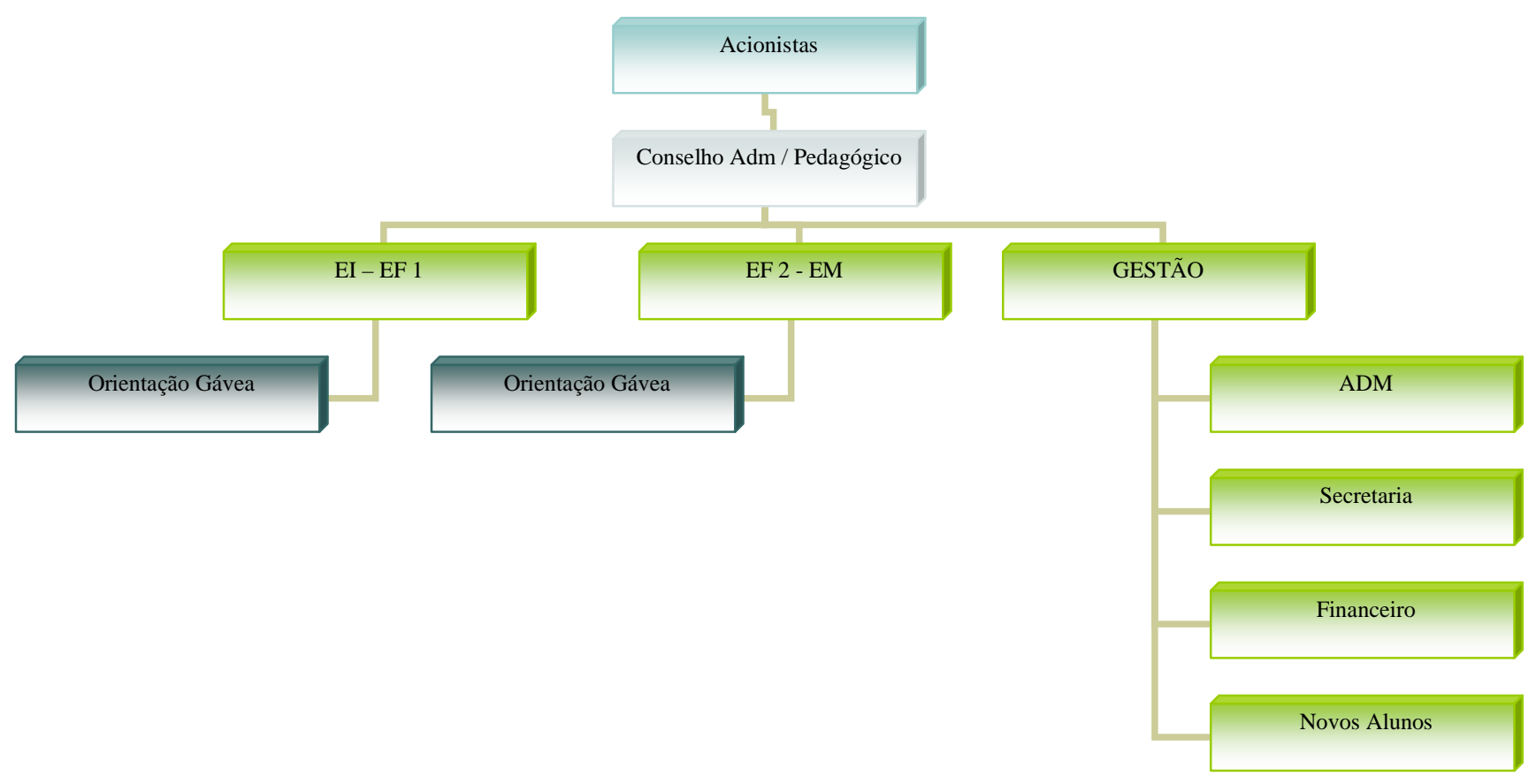

O Organograma da Escola Parque Barra é controlado pelo grupo de acionistas, constituído pela Escola Parque Gávea e um sócio-financeiro. Um conselho administrativo e pedagógico é responsável pelas tomadas de decisões no nível tático. Estas duas estruturas não estão presentes no dia-a-dia da unidade Barra, que fica a cargo da Coordenadoria do Ensino Infantil e Ensino Fundamental I, da Coordenadoria do Ensino Fundamental II e Ensino Médio e da Coordenadoria de Gestão. As Coordenadorias pedagógicas recebem orientação direta da unidade da Gávea, com constantes treinamentos e avaliações. A equipe de gestão é dividida em Administração, Secretaria, Financeiro e Novos Alunos.

A Administração é responsável pelos estoques, sistemas, manutenção e pela limpeza. A Secretaria é dividida em pedagógica (documentação dos alunos), atendimento de pais e professores. O Financeiro da unidade da Barra limita-se ao 
recebimento e cobrança das mensalidades. O setor de Novos Alunos, além de responsável pela recepção e ambientação dos alunos novos, faz a captação, estabelecendo convênios, parcerias e promovendo reuniões não-pedagógicas. Os convênios são feitos com associações e condomínios da região, com descontos sendo oferecidos aos mesmos. As reuniões são palestras culturais com diferentes temas abordados, e o público convidado é formado por pais, alunos e funcionários da escola. Pais, que já tenham entrado em contato, seja por telefone ou visita também são convidados.

\subsection{Serviços}

A Escola Parque Barra tem como seu serviço principal, toda grade curricular do ensino Básico (a ser concluída no inicio de 2008 - Item 4.6.). O Centro de Atividades complementa o "mix de serviços" oferecidos, com aulas pagas a parte da mensalidade escolar e fora do horário regulamentar. Capoeira, inglês, futebol, vôlei, judô, ballet, curso das histórias, oficina de artes e teatro são as atividades oferecidas fora do horário escolar.

Serviços complementares também são oferecidos por meio de terceirização, como a cantina, a condução e venda de uniforme.

\subsection{Mercados-Alvo}

A Escola Parque Barra está situada no bairro da Barra da Tijuca, porém próxima ao bairro do Recreio dos Bandeirantes. Desta forma, os dois bairros são apontados como mercados de atuação da empresa na questão geográfica. Segundo o censo de 2000 promovido pelo IBGE, a Região Administrativa em que a unidade está inserida é a que mais cresce no município do Rio de Janeiro. O Anexo 04 confirma os bairros como principal localização das atuais famílias da Escola Parque Barra. 
O perfil demográfico possui algumas variáveis descritas abaixo:

Idade. Com turmas começando na Educação Infantil I progressivas até o Ensino Médio, a idade do público-alvo vai dos dois aos 18 anos de idade. Há uma tendência natural de jovens que estejam iniciando segmentos da grade curricular (Anexo 11).

Religião. A Escola Parque Barra está posicionada no mercado como uma opção não-religiosa, sendo, portanto, considerada uma instituição laica. No entanto, não há ações específicas de atração de alunos de acordo com sua religião, sendo todos aceitos. Desta forma, a variável "Religião" não é relevante no estabelecimento do público-alvo.

Ocupação. A investigação nos registros das duas unidades permite traçar um comparativo entre Gávea e Barra (Anexo 03). Ainda que o ranking apresente a mesma ordem de profissões, com administradores em primeiro lugar e profissionais ligados à classe artística em segundo, as famílias da Escola Parque Barra possuem um perfil profissional mais técnico-administrativo, enquanto na Escola Parque Gávea predomina um perfil mais "cultural-artístico".

Idioma. Apesar de incluir disciplinas de línguas no currículo, como Francês, Inglês e Espanhol, a Escola Parque Barra é unilíngüe, não sendo indicada a famílias que pretendem que seus filhos sejam educados em mais de uma língua.

Renda. A mensalidade da Escola Parque Barra varia entre $R \$ 883,81$ a $R \$$ 1.024,46. A análise da concorrência (item 4.10) indica que está inserida na faixa mais alta do mercado de escolas não-bilíngües. Sendo assim, pode-se afirmar que o mercado-alvo na variável "Renda" é direcionado às classes sociais " $A$ " e "B".

Variáveis como Sexo e Raça não possuem relevância no estudo de mercado da Escola Parque Barra.

\section{Perfil Psicográfico:}

Estilo de vida. Os bairros da Barra da Tijuca e do Recreio dos Bandeirantes são bairros considerados "novos" no município do Rio de Janeiro. Da mesma 
maneira, seus moradores são considerados como pertencentes a uma "sociedade emergente". Esta denominação costuma representar grupos sociais constituídos por pessoas que ascenderam economicamente, mas que não trazem uma estrutura cultural e intelectual em suas histórias de vida e que se formam pelo processo migratório entre os bairros de uma cidade. Essas sociedades são vistas pelos grupos sociais tradicionais como sendo formadas por "novos ricos".

Personalidade. O perfil do cliente da Escola Parque Barra é de sofisticação, não conservador e exigente. Aceita pagar um preço acima do mercado, mas "cobra" um projeto pedagógico em constante atualização e espera sempre novidades. Existe também a ambição que seu filho alcance uma formação cultural aliada a bons resultados e encaminhamento profissional.

\section{Perfil Comportamental:}

Ocasião. O cliente procura a Escola Parque Barra normalmente entre os meses de outubro e fevereiro. A força de vendas é aumentada nesta época.

Benefícios. Procura por qualidade no ensino juntamente com cultura. Busca também benefícios no longo prazo na formação do filho.

Status do usuário. Os clientes da Escola Parque Barra podem ser divididos em três grupos: os atuais, os que já procuraram a empresa em alguma ocasião e os potencias clientes que não conhecidos. Por estar em processo de expansão, o segundo grupo pode ter alguma desconfiança na instituição no momento do contato, sendo um importante alvo mesmo no curto e médio prazo.

Índices de utilização. Esta segmentação seria o caso de famílias com dois ou mais filhos. É importante a identificação destes grupos para que descontos sejam oferecidos.

Status de fidelidade. O índice de desistências na Escola Parque Barra é menor que $5 \%$, sendo o cliente considerado leal à marca. 
Atitude em relação ao produto. O serviço escolar permite diversas interpretações e percepções. A interface com os pais é constante, gerando inúmeros pontos de vistas. Algumas famílias têm atitude hostil, outras positivas, algumas de desconfiança e desconforto. As diferentes reações também são manifestadas pelos alunos e obrigam que os funcionários da empresa possuam habilidade em lidar com pessoas com a competência necessária.

A segmentação de grupos descrita acima converge para um nicho de mercado quando analisadas de uma maneira ampla. O perfil do cliente da Escola Parque Barra é bem definido:

- É morador da Barra da Tijuca ou Recreio dos Bandeirantes;

- Procura uma escola não ligada a religião;

- Paga um preço acima do mercado, mas é exigente;

- Busca "adquirir cultura" através da educação;

- Não procura escolas bilíngües;

- Preocupa-se com resultados, mas não é uma obsessão.

\subsection{Concorrentes}

Tabela 4.1. Concorrentes

\begin{tabular}{|c|c|c|c|c|c|c|}
\hline & Segmentos da grade & Alunos & Mensalidade & Característica & Enem (rede toda) & Mercado \\
\hline Santo Agostinho & Todos & 2500 & $R \$ 673$ a $R \$ 1.038$ & Religioso & $2^{0}$ lugar - 81,66 & 60 \\
\hline Cruzeiro & Todos & 1400 & $\mathrm{R} \$ 882$ a $\mathrm{R} \$ 1.064$ & Bilíngüe & $4^{\circ}$ lugar $-76,67$ & 144 \\
\hline CEEI & Todos & 800 & $\mathrm{R} \$ 896$ a $\mathrm{R} \$ 1.120$ & - & - & 15 \\
\hline Bahiense & Ens. Fundamental e Médio & - & $R \$ 550$ a $R \$ 890$ & - & mais do $10^{\circ}-70,46$ & 46 \\
\hline Escola Britânica & 2 a 9 anos & 250 & acima de $R \$ 1.500$ & Bilíngüe & mais do $10^{\circ}-70,69$ & 82 \\
\hline P.H. & Ens. Fundamental e Médio & - & $\mathrm{R} \$ 1.100$ a $\mathrm{R} \$ 1.520$ & - & 3ㅇlugar - 80,33 & - \\
\hline St. John & Todos & - & $R \$ 551$ a $R \$ 936$ & - & - & 15 \\
\hline EP BARRA & Todos & 654 & $\mathrm{R} \$ 883$ a $\mathrm{R} \$ 1.024$ & - & 5logar - 75,68 & 36 \\
\hline
\end{tabular}

A opção de escolas varia de acordo com diversos atributos vistos no item anterior. Apesar de estar inserida em uma faixa de mercado segmentada, a empresa 
concorre com escolas que aparentemente estão em outra faixa de mercado. Isto acontece, pois uma escola religiosa, como por exemplo, o Santo Agostinho, pode possuir uma qualidade percebida pelo cliente mais marcante que a religião. Se por um lado o cliente pode optar pela matrícula no colégio sem ao menos consultar a Escola Parque Barra, pois procura um ensino religioso, um outro cliente pode considerar que o colégio tem uma proposta pedagógica bem desenvolvida e que os resultados no vestibular/Enem são ótimos. Desta forma o Santo Agostinho, mesmo sendo religioso, passa a ser um concorrente direto da Escola Parque Barra.

O mesmo acontece com o Colégio Cruzeiro. Apesar de bilíngüe, é um concorrente da Escola Parque Barra. Com um projeto pedagógico apurado e com apoio do governo alemão, que permite mensalidades não tão altas para um Colégio bilíngüe, apresenta ainda expressivos resultados no vestibular/Enem. A ampla infraestrutura do espaço também posiciona a instituição como uma das principais concorrentes.

O CEEI (Centro Educacional Espaço Integrado) é o que mais se assemelha ao nicho de mercado da Escola Parque Barra, com proposta pedagógica semelhante, não-bilíngüe e laica. Inclusive, muitos alunos que finalizavam o Ensino Fundamental II migravam para Escola Parque Barra. Instituiu o segmento do Ensino Médio este ano.

O quarto concorrente principal é o Colégio $\mathrm{PH}$, que apesar de valorizar o resultado em detrimento da formação, é uma opção não-religiosa e não-bilíngüe de ensino de qualidade. Neste caso existe o elemento "experiência". Muitas vezes, os pais fazem uma opção por um estudo rígido e no meio do percurso mudam de idéia, o mesmo acontecendo na outra via.

As demais instituições incluídas na tabela acima não chegam a ser consideradas concorrentes, por razões de percepção de qualidade, preço e proposta pedagógica muito diferente, como a Escola Britânica, que forma o aluno nos moldes ingleses. 


\subsection{Diferenciação sobre a concorrência}

Como analisado no item anterior, os principais concorrentes da Escola Parque Barra são o Santo Agostinho, Colégio Cruzeiro, CEEl e Colégio PH. Pontos que diferenciam a instituição das demais:

Projeto pedagógico estruturado. A empresa tem uma proposta pedagógica bem definida e clara (Anexo 10). O serviço oferecido é entendido pelas famílias antes da matrícula.

Baixa Elasticidade-Preço. Apesar de influenciar a decisão das famílias, a variável preço é secundária para o público-alvo, que em geral, considera a qualidade pedagógica e os resultados de aprendizagem dos filhos mais determinante no momento da escolha.

Tradição. Os 35 anos em educação da Escola Parque Gávea, sempre com imagem positiva no mercado, é um fator muito relevante na escolha.

Indicadores de sucesso. Comprovação, através de indicadores como os resultados no vestibular e no ENEM (Exame Nacional do Ensino Médio - Anexo 12), que a qualidade da proposta pedagógica não significa fragilidade técnica dos alunos.

Aluno autônomo. $O$ desenvolvimento do senso crítico e de responsabilidade é um diferencial na Escola Parque Barra. As famílias sentem-se parceiras e apoiadas na formação dos filhos.

Espaço Físico. De acordo com sua filosofia, a Escola Parque Barra estruturou seu espaço de forma que o aluno esteja em contato com a natureza.

Mix de Serviços. Os serviços complementares oferecidos são determinados pela demanda dos pais e a cultura do bairro. A empresa está sempre desenvolvendo em conjunto com as famílias novos cursos e serviços. 


\subsection{Operações}

A Escola Parque Barra, sendo uma filial, possui uma estrutura mais simplificada do que a matriz. As diretorias financeira, de marketing, pedagógica e geral situam-se na matriz, na Gávea. A Unidade da Barra tem suas operações restritas aos agentes da linha de frente, como coordenadores, professores e outros funcionários.

Cada diretor faz, no mínimo, duas visitas semanais a filial e no fim de cada mês, um relatório é enviado à matriz pelo coordenador responsável. Os coordenadores da filial são ex-coordenadores da matriz, com experiência de no mínimo cinco anos na empresa. Existe, no entanto, a preocupação em diminuir gradativamente a supervisão e transferir a referência dos diretores para os coordenadores. Além da escassez de tempo, os diretores estão menos em contato com os alunos e pais do que os coordenadores. Apesar de reclamações iniciais, o processo já é bem aceito e é uma tendência natural para uma empresa em crescimento.

Os eventos do calendário escolar, no entanto, são feitos isoladamente. Cada unidade de negócio possui uma feira do livro, uma semana cultural, uma festa junina, torneios esportivos próprios, entre outras atividades.

\section{Tecnologia.}

Os diretores da Escola Parque Barra acreditam que há necessidade de investimentos na área tecnológica. Atualmente, a instituição possui laboratório de computação e computadores nas salas de aula, mas considera que a tecnologia oferecida não tem aplicação na prática como deveria.

O investimento necessário anual estimado é de $R \$ 100.000,00$ em equipamentos e instalações e $\mathrm{R} \$ 100.000,00$ em manutenção e licenças. Entre os projetos previstos, está o desenvolvimento de llhas de Computação espalhadas pelo espaço da escola, dobrar o número de computadores nas salas de aula (atualmente com nove em cada uma) e uma Intranet para consulta de alunos e professores. 
Paralelamente, existe um trabalho junto aos professores para que a tecnologia oferecida seja inserida de maneira apropriada na dinâmica e metodologia de aula.

\subsection{Capacidades e Limitações}

Situado no condomínio Pedra de Itaúna, na Barra da Tijuca, o terreno possui 8.660 metros quadrados. O percentual de área construída prevista já é o limite permitido pela legislação vigente, sendo um elemento limitador.

O maior limitador, no entanto, é o período escasso que se tem para construir durante o ano, cerca de 40 dias, em decorrência do inicio das atividades escolares. Esta trava incide diretamente na estratégia da empresa, pois não pode adiantar seu cronograma de expansão diante de uma demanda reprimida.

\subsection{Análise dos recursos da empresa e Administração}

Recursos Humanos. A Escola Parque Barra possui 83 funcionários, entre coordenadores, professores, administradores e equipe de manutenção. Existe a cultura de se promover os profissionais já inseridos no processo, sem muitas contratações externas, o que explica a baixa rotatividade. O processo de admissão é feito normalmente no final do ano, de acordo com o ano letivo. $O$ treinamento é feito por funcionários da Escola Parque Gávea na própria unidade da Barra.

Recursos Financeiros. Os recursos no primeiro ano foram compostos por um empréstimo contraído junto ao BNDEs e por recursos dos sócios. O BNDEs já foi quitado no fim de 2005, enquanto os sócios vão ser pagos integralmente no fim de 2006. A empresa utilizará recursos próprios para as obras de expansão da unidade e investimentos em tecnologia.

Remuneração. A base salarial utilizada é acima da estabelecida pelo Sindicato de professores. Além do salário fixo, todos os funcionários, do porteiro ao coordenador recebem em abril uma remuneração variável de acordo com número de 
alunos matriculados. A medida, que não é comum no ramo escolar, motiva e envolve todos na responsabilidade de crescimento da empresa. Uma reunião anual conduzida pelo os diretores apresenta os resultados e as metas a todos.

\subsection{Estilo de administração e clima organizacional}

A Escola Parque Barra possui uma estrutura de gestão compartilhada entre os sócios-diretores, isto é, as tomadas de decisões são feitas em conjunto. A equipe responsável pela execução possui características de liderança nos respectivos setores e segmentos.

Apesar das principais tomadas de decisões serem em conjunto, cada sócio possui sua autonomia na sua área de trabalho para desenvolver os projetos previstos e alcançar seus objetivos estabelecidos para cada ano ou período.

Os funcionários de uma escola, qualquer nível, estão em permanente contato com jovens e crianças. Desta forma, são escolhidos de acordo com algumas determinadas características que privilegiam a confiabilidade e facilidade de comunicação. Estas mesmas características formam a base do Código de Convivência adotado. "Programas de Qualidade Total" não são adotados na instituição, que enxerga na sua própria experiência a melhor maneira de estabelecer um relacionamento saudável entre os funcionários.

$\mathrm{Na}$ visão dos diretores, um dos principais fatores da baixa rotatividade na empresa deve-se justamente ao clima saudável e amistoso existente na Escola Parque Barra. Outro fator levantado é a motivação do envolvimento em um trabalho diferenciado e de qualidade no meio educacional.

\subsection{Orientação para o Marketing}

Imagem corporativa. A Instituição é ligada a cultura e a qualidade do ensino. Em um recente trabalho de uma consultoria, determinou-se quais as principais 
interfaces com o cliente para que a imagem continue da mesma maneira: reunião de pais, documentação, comemorações, coordenadores e professores, comunicações e divulgação na mídia, portaria, cantina e serviços terceirizados, metodologia de avaliação e a cobrança.

Inteligência de Marketing e Pesquisas. A empresa não possui departamento de pesquisa e avaliação em marketing. A contratação das pesquisas é feita diretamente pelo diretor administrativo da escola e os seus resultados são aplicados na prática pelos próprios diretores de cada área.

Atendimento ao cliente. A empresa personaliza seu atendimento com reuniões de pais menores e periódicas, e individualmente quando necessário.

Força de vendas. A Escola Parque Barra possui uma área na empresa direcionada somente à captação de novos alunos (Item 4.6.). Além de treinamento específico, estabelece convênios com condomínios e associações.

Comunicação. A empresa não investe em vinculação de anúncios e propagandas. A imagem é construída pelo "boca a boca" e pela contratação de uma assessoria de imprensa.

Cliente. O aluno e seus pais são os clientes da Escola Parque Barra. Os diretores entendem que a instituição não faz a "capacitação de professores", isto é, não privilegia os professores em detrimento dos alunos.

Inovação. A filosofia pedagógica adotada não é estática, sofrendo constantes avaliações. Apesar de dificuldade de implantação de novas tendências e idéias, existem estudos, pesquisas e parcerias na área.

\subsection{Comportamento com a gestão ambiental e a responsabilidade social}

A Escola Parque Barra está incorporando ao projeto pedagógico, trabalhos ligados à esfera ambiental e de cidadania. A empresa entende seu papel na 
sociedade local de referência cultural e social. Os programas em desenvolvimento têm, além dos benefícios à sociedade, a introdução de valores positivos nos alunos, pois estes participam ativamente dos projetos.

Vestibular Comunitário. Mesmo modelo adotado há oito anos na sede da Gávea. Inclui a participação de alunos e ex-alunos (Anexo 13).

Aulas de apoio para rede pública (ECEP). A Escola Parque Barra abrirá turmas em horários ociosos como apoio a alunos da rede pública. Modelo adotado na sede da Gávea também.

Alfabetizacão de adultos. Aberto a comunidade local com "divulgação" de alunos e funcionários. Inclui noções de uso de computadores. Modelo adotado na sede da Gávea também.

Horta orgânica. Ainda em estudo de viabilidade, a horta orgânica, localizada no próprio terreno da Escola Parque Barra, vai abastecer a cantina e funcionários. Os projetos envolvendo Cidadania e Meio Ambiente vão ser incorporados ao currículo dos alunos de forma gradativa, com evidências físicas como certificados de participação. Historicamente, a empresa sempre foi associada a uma gestão ambiental responsável e atuação ativa em projetos com a comunidade. Os diretores entendem que este atributo à marca tem que se manter na sede da Barra da Tijuca.

\subsection{Resumo do desempenho da unidade da Barra da Tijuca}

A Escola Parque Barra apresenta os seguintes números referentes ao seu desempenho empresarial:

\begin{tabular}{|c|r|r|r|r|r|}
\hline \multirow{2}{*}{ Desempenho } & \multicolumn{3}{|c|}{ Consolidado } & \multicolumn{2}{|c|}{ Meta } \\
\cline { 2 - 6 } & 2004 & 2005 & 2006 & 2007 & 2008 \\
\hline Alunos & 269 & 452 & 654 & 850,2 & 1063 \\
\hline Receitas & 100 & 168,03 & 243,12 & 316,06 & 395,07 \\
\hline Lucro Bruto & $25,08 \%$ & $30,07 \%$ & $31,26 \%$ & $32,38 \%$ & $39,06 \%$ \\
\hline
\end{tabular}


No ramo escolar, em geral, pode-se considerar o ano corrente, após o mês de abril, como consolidado, pois as receitas das mensalidades variam muito pouco e as despesas já foram previstas. Sendo assim, para efeitos de análise o presente ano, apesar de ainda em curso, está considerado como consolidado.

De acordo com os números acima, a curva de receita apresenta crescimento de $68 \%$ em 2005 e 45\% em 2006. A variação da receita está ligada diretamente ao número de alunos, pois além da mensalidade responder por aproximadamente $98 \%$ da receita, os outros serviços adquiridos são influenciados pelo número de alunos, como cantina e centro de atividades. As metas de crescimento para 2007 e 2008 são respectivamente $30 \%$ e $25 \%$. A diminuição do percentual de crescimento é natural, pois nos primeiros anos há a tendência de rápida expansão, com diminuição nos anos seguintes. O lucro bruto tem ganhos de escala e apresenta crescimento mais acelerado que a receita, pois o custo fixo é diluído por mais alunos.

A previsão deve levar em conta esta dificuldade da manutenção de altas taxas de crescimento. Desta forma, 30\% e 25\% podem ser consideradas estimativas otimistas, apesar do recente histórico de sucesso da empresa.

O crescimento da empresa foi programado com o equilíbrio de recursos próprios e de terceiros (BNDES). Desta forma, a empresa conseguiu realizar os investimentos necessários sem descapitalizar muito os sócios e sem pagar muitos juros. Além de financeiramente saudável, a mescla de recursos foi benéfica para o planejamento financeiro, pois foram estabelecidas metas reais de atingimento e desembolsos.

Outra razão para o bom desempenho da empresa se deve a força do projeto em uma visão ampla. O planejamento nas áreas estratégicas de atuação foi fundamental para o bom andamento:

- A participação nos lucros aberta a todos e as reuniões participativas constantes contribuíram para o envolvimento efetivo dos funcionários; 
- O senso de oportunidade em oferecer um ensino de qualidade em um mercado em rápida expansão e carente de opções;

- A força da marca, que apesar de não ter tanta visibilidade no mercado, tem repercussão positiva quando disseminada;

- Know-how adquirido na matriz na Gávea filtrou as experiências ruins e as boas.

\subsection{Análise de SWOT Escola Parque Barra}

Após realizar as análises, como o "CVA", o "Mapa de Posicionamento", "Estratégias Genéricas e de Liderança" e "as Cinco forças competitivas", e levantar os dados primários e secundários relevantes à empresa, pode-se definir os pontos fortes e fracos do ambiente interno e as oportunidades e ameaças do ambiente externo.

\begin{tabular}{|c|c|}
\hline \multicolumn{2}{|c|}{ Ambiente Interno } \\
\hline Forças & Deficiências \\
\hline $\begin{array}{l}\text { Força da marca } \\
\text { Bons professores } \\
\text { Projeto pedagógico } \\
\text { Espaço Físico } \\
\text { Flexibilidade } \\
\text { Atualização } \\
\text { Diretores “despertos" para } \\
\text { uma gestão profissional } \\
\text { Baixa inadimplência } \\
\text { Acolhimento aos alunos }\end{array}$ & $\begin{array}{l}\text { Preço } \\
\text { Localização "afastada" } \\
\text { Imagem liberal pejorativa } \\
\text { Espaço Físico } \\
\text { Percepção tecnológica falha } \\
\text { Espaços entre as séries } \\
\text { Falta de histórico da unidade } \\
\text { Diretoria ausente } \\
\text { Transição de lideres } \\
\text { Aplicação prática pequena }\end{array}$ \\
\hline \multicolumn{2}{|c|}{$\begin{array}{l}\text { Ambiente Externo } \\
\text { Ameaças }\end{array}$} \\
\hline $\begin{array}{l}\text { Concorrência fraca no nicho } \\
\text { Crescimento Barra e Recreio } \\
\text { Valorização do ensino de qualidade } \\
\text { "Colapso" da rede pública } \\
\text { Diminuição da taxa de juros } \\
\text { Crescimento da liberdade de } \\
\text { pensamento na sociedade }\end{array}$ & $\begin{array}{l}\text { Crise econômica } \\
\text { Novas regulamentações da prefeitura } \\
\text { Novos entrantes no nicho }\end{array}$ \\
\hline
\end{tabular}

\section{Forcas}


ÿ Força da marca - A marca "Escola Parque" é recebida positivamente no contato com cliente.

ÿ Bons professores - Além de ceder alguns professores "consagrados", a experiência da Gávea contribuiu para a contratação eficiente dos professores. Os salários acima do mercado também são fundamentais para contratação e manutenção de bons profissionais.

ÿ Projeto pedagógico - A proposta adotada pela instituição é uma característica marcante na empresa, sendo uma das principais forças do ambiente interno.

ÿ Espaço Físico - O terreno de quase 9mil metros quadrados é arborizado e arejado, estando de acordo com a proposta pedagógica.

ÿ Flexibilidade - A Escola Parque Barra não é um ambiente rígido e repressor. A flexibilidade também se manifesta na empresa em si, permitindo, por exemplo, que a proposta pedagógica seja adaptada de acordo com as mudanças no mundo.

ÿ Atualização - A distância do mundo real é pequena, e os envolvidos estão sempre estudando novos estudos, tecnologias, tendências ou fatos.

ÿ Diretores “despertos” para uma gestão profissional - A preocupação em profissionalizar a administração é grande. A tomada de decisão no nível estratégico não é realizada mais sem fundamentação palpável.

ÿ Baixa inadimplência - Segundo os diretores, a Escola Parque Barra tem umas das taxas mais baixas do mercado escolar, proporcionando segurança no planejamento do médio e longo prazo.

ÿ Acolhimento aos alunos - $\mathrm{O}$ aluno novo é apoiado por um projeto de adaptação e recebe suporte até se ambientar à nova escola.

\section{Deficiências}

ÿ Preço. A mensalidade praticada é acima do mercado. Apesar do custobenefício positivo, os clientes são mais exigentes.

ÿ Localização "afastada". A localização é no final da Barra da Tijuca, quase no Recreio dos Bandeirantes. O transporte escolar deve ser eficiente.

ÿ Imagem liberal pejorativa. Herança herdada da unidade da Gávea acompanha a imagem da Escola. Apesar de constantes campanhas internas e postura externas frente a sociedade, episódios isolados relacionados a 
drogas, indisciplina e permissividade ainda têm influência negativa na imagem da instituição.

ÿ Espaço físico. Apesar de estar relacionado como um ponto forte também, o espaço físico ainda é deficiente na infra-estrutura de lazer e esporte. $O$ ginásio ainda não foi construído e o crescimento do número de alunos pode sobrecarregar as opções de atividades ao ar livre.

ÿ Percepção tecnológica falha. Segundo a pesquisa de satisfação entre pais da Escola Parque Barra, o atributo "informática" foi classificado abaixo dos outros serviços oferecidos. Investimentos já foram feitos na área, e outros estão previstos, mas o padrão tecnológico dos clientes está aumentando e por conseqüência, a exigência também.

ÿ Espaçamento entre as séries. A grade curricular incompleta é um fator inibidor para alguns pais. Não pela falta de histórico somente, mas também pela falta de convivência com alunos de todas as idades.

ÿ Falta de histórico da unidade. A Escola Parque Barra tem 05 anos de existência, e ainda não tem turmas formadas e resultados práticos como 0 vestibular e ENEM.

ÿ Diretoria ausente. Um dos pontos fracos da unidade da Barra da Tijuca é a falta da presença física de um diretor no dia a dia. O comando fica a cargo de coordenadores, que mesmo bem instruídos, capacitados e supervisionados, não possuem o "peso" de um membro da diretoria. Se por um lado faz parte da estratégia da empresa, a descentralização do poder, por outro lado, o cliente, no caso, os pais, pode sentir falta de uma referência maior.

ÿ Transição de líderes. Este problema é da empresa toda, tanto na Gávea como na Barra da Tijuca. Atualmente, o modelo de gestão, por mais que esteja caminhando para um profissionalismo e uma descentralização do poder, ainda é extremamente depende das pessoas que estão no comando, e não do cargo.

ÿ Aplicação prática pequena. Os estudos realizados, as pesquisas encomendadas, as novas tendências percebidas e as conclusões de experiências próprias demoram a ser implantadas na empresa.

\section{Oportunidades}


ÿ Concorrência fraca no nicho. A faixa de mercado em que está inserida (Não-bilíngue, Laica, Classes "A" e "B", Privilegiando a formação cultural e Barra da Tijuca e Recreio) não possui nenhum concorrente com grande potencial.

y Crescimento dos bairros da Barra da Tijuca e Recreio dos Bandeirantes. Os bairros estão entre os que mais crescem em população no município do Rio de janeiro.

ÿ Valorização do ensino de qualidade. A disputa por melhores posições no mercado de trabalho é cada vez mais intensa, e a diferença na formação escolar já começa a ser percebida no ensino básico. A preparação dos jovens é preocupação cada vez mais intensa, valorizando-se assim o ensino de qualidade.

ÿ “Colapso" da rede pública. O ensino público oferece cada vez menos competitividade em relação ao ensino privado.

ÿ Diminuição das taxas de juros. As recentes diminuições das taxas de juros básicas no país facilitam o contrato de empréstimos. É uma opção para acelerar o processo de expansão

ÿ Crescimento da "liberdade de pensamento" na sociedade. Em um mundo cada vez mais globalizado e com fluxo de informações mais acelerado, a tendência é a valorização de instituições escolares voltadas ao desenvolvimento cultural e social do aluno.

\section{Ameacas}

ÿ Crise econômica. Como visto no item 3.1.9, a queda do nível de renda afeta diretamente o setor de escolas privadas. A empresa está sujeita, portanto, a variações econômicas verificadas na sociedade.

ÿ Novas regulamentações. Como qualquer empresa, a Escola Parque Barra é vulnerável a questões de âmbito legal. Recentemente, a prefeitura editou uma medida, em que terrenos públicos poderiam ser vendidos, exatamente a situação da instituição. A medida está arquivada no momento. (Anexo 14)

$\ddot{y}$ Novos entrantes no nicho. A Escola Parque Barra atua praticamente sozinha no nicho em que está inserida. Existe, portanto, a oportunidade aberta a outras empresas, principalmente escolas com nome "forte" na Zona Sul, a entrar neste mercado. 
ÿ Ensino a distância. O sistema de ensino a distância ainda está iniciando, mas pode ser no futuro uma ameaça ao ensino tradicional.

\subsection{Fatores Críticos de Sucesso}

Após o levantamento dos pontos fortes e fracos da empresa, e a análise das oportunidades e ameaças do ambiente externo, pode-se eleger as condições necessárias para que a Escola Parque Barra tenha sucesso no ramo escolar. A empresa deve ter um desempenho no mínimo satisfatório nestas condições.

1) Proposta pedagógica e disciplinar clara e atualizada. $O$ posicionamento no mercado escolar está intimamente ligado a este fator. Neste ramo, o cliente tem uma necessidade ainda maior de saber o que está adquirindo, pois envolve um projeto de vida que ele está desenhando para o filho. Excetuando raríssimas situações, é senso comum que a matrícula de um aluno não feita visando apenas um ano de curso. Desta maneira, a clareza do serviço prestado é fundamental no processo decisório.

O mercado entende que a Escola Parque Barra tem uma proposta pedagógica diferenciada e atualizada. O desenvolvimento "autônomo" dos alunos é, no entanto, ponto chave na percepção de sua imagem. A liberdade é vista como "permissividade", e afasta muitos clientes preocupados com a disciplina dos filhos.

\section{2) Garantia de viabilidade e implantação das decisões estratégicas. A} inclinação para uma gestão de negócios profissional deve ser acompanhada por uma postura realista. Não adianta realizar uma pesquisa de mercado, tirar conclusões, e na prática não executar a estratégia decidida, seja por falta de viabilidade, falha de comunicação ou administração falha. As decisões no nível estratégico devem ser disseminadas para os planos táticos e operacionais.

3) Organização dos processos vitais. Os processos de funcionamento devem ser padronizados e organizados. A gestão baseada somente na experiência dos líderes pode ser fatal no processo de expansão ou transição, pois em 
determinado momento, a execução de uma tarefa, projeto ou evento pode ser comprometida pela ausência dos mesmos.

4) Atenção e preocupação contínua com o aluno. Os pais decidem a matrícula dos filhos e os diretores definem o melhor funcionamento do projeto, mas estes fazem parte dos "bastidores". O "espetáculo" acontece na verdade no "palco", e as "atrações principais" são os alunos e professores. O desempenho acadêmico e pessoal dos alunos é manifestação da qualidade do serviço. Um projeto só é bem elaborado se proporcionar benefícios ao aluno, e não a pais ou a própria instituição.

5) Estrutura física de qualidade. Uma escola que deseja se posicionar como referencia no mercado, deve oferecer uma estrutura de qualidade. Áreas de lazer e esporte, laboratórios de computação, física, química e robótica, cantina adequada e instalações em geral, devem existir e ser bem cuidadas.

\subsection{Cadeia de valores Escola Parque Barra}

Eleitos os FCS (Fatores Críticos de Sucesso), pode-se desenvolver a cadeia de valores da Empresa, destacando os atributos que influenciam os pontos estratégicos da Escola Parque Barra. 


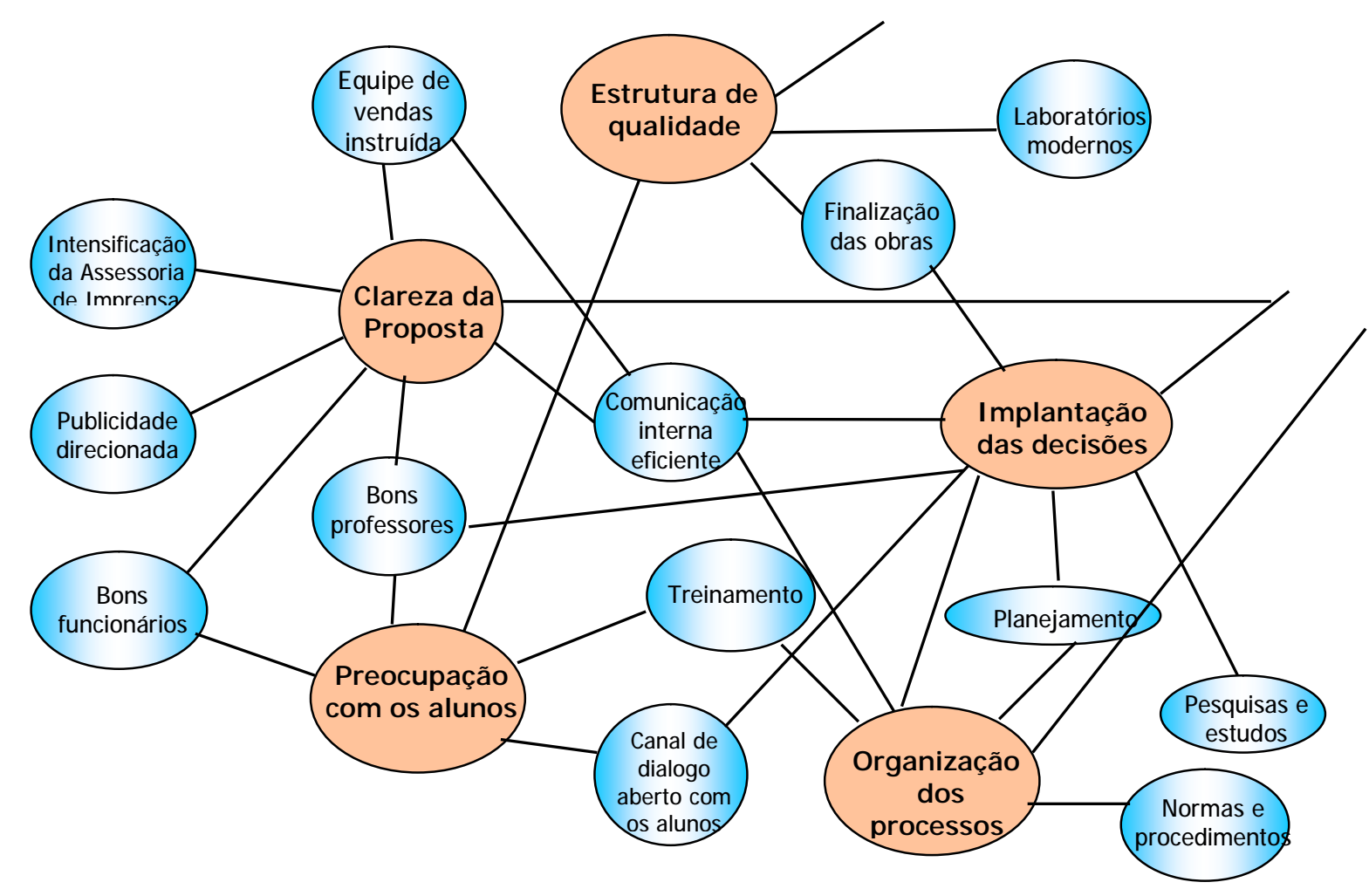

Os balões azuis são atributos que influenciam os pontos estratégicos, nos balões vermelhos.

\subsection{Estratégia no nível de negócios}

Como visto no item 3.2.7, a estratégia adotada pela Escola Parque Barra é o "Desenvolvimento do mercado", ou seja, a aquisição dos produtos já oferecidos por novos clientes. A empresa não deve inventar novos produtos ou modificar o seu, a estratégia é aperfeiçoar o negócio existente para atração de clientes em potencial.

\subsection{Objetivos e Estratégias de marketing}

Os objetivos de marketing devem ser específicos, mensuráveis, ambiciosos, realistas e com prazos bem definidos. Os caminhos, ou as estratégias de marketing, que levarão a Escola Parque Barra a atingir seus objetivos devem claros e podem 
contribuir para mais de um objetivo. A matriz abaixo repete os pontos que se deseja alcançar, e interrelaciona com os possíveis caminhos a serem seguidos.

\begin{tabular}{|c|c|c|c|c|c|c|c|}
\hline & \multicolumn{7}{|c|}{ ESTRATÉGIAS } \\
\hline OBJETIVOS & 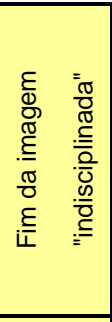 & 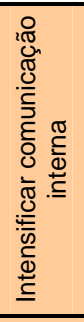 & 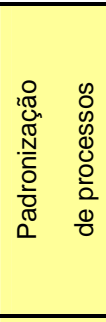 & 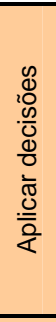 & 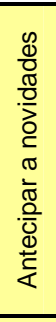 & 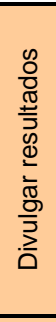 & 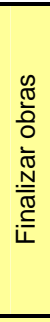 \\
\hline Proposta pedagógica e disciplinar clara e atualizada & $\mathbf{x}$ & $\mathbf{x}$ & & & $\mathbf{x}$ & $\mathbf{x}$ & \\
\hline Garantia de viabilidade e implantação das decisões estratégicas & & $\mathbf{x}$ & $\mathbf{x}$ & $\mathbf{x}$ & & & \\
\hline Organização dos processos vitais & & $\mathbf{x}$ & $\mathbf{x}$ & $\mathbf{x}$ & & & \\
\hline Atenção e preocupação contínua com o aluno & $\mathbf{x}$ & $\mathrm{x}$ & $\mathbf{x}$ & & & $\mathbf{x}$ & $\mathbf{x}$ \\
\hline Estrutura física de qualidade & & & & $\mathbf{x}$ & $\mathbf{x}$ & & $\mathbf{x}$ \\
\hline
\end{tabular}

O desempenho das estratégias traçadas pode ser medido por pesquisas de mercado, controle de índices, taxas, resultados e metas e, principalmente, ouvindose os stackholders do processo. 


\section{CAPÍTULO V - CONCLUSÕES / RECOMENDAÇÕES}

O processo de expansão da Escola Parque Barra está bem estruturado. De fato existe uma demanda reprimida no mercado com vontade de adquirir o serviço que a empresa oferece. A análise da pesquisa exploratória deste estudo traça algumas características das famílias classe "A" e "B" residentes na Barra da Tijuca e Recreio dos Bandeirantes. Nota-se o desejo pelo "status intelectual". O alto poder aquisitivo das famílias permitiu que muitas experiências e bens fossem adquiridos ao longo do tempo. A cultura, no entanto, não é um bem tangível, e uma das formas de aproximação é através de instituições de ensino. Levando-se em conta também a análise da concorrência, a Escola Parque Barra aparece como a principal opção para esta demanda no nicho de mercado em que está inserida.

O preço das mensalidades praticado é acima do mercado, mas entende-se como um bom custo-benefício. O investimento, no entanto, faz diferença no dia a dia das famílias, e a exigência por serviços de qualidade é grande. Sendo assim, os Diretores da empresa devem estar sempre alertas não só para o nível de serviço oferecido, mas também pelo nível de serviço percebido pelo cliente. Um exemplo prático é o caso da informática, que por mais que não esteja de um modo geral abaixo dos concorrentes, é um serviço visto como deficiente pelo os pais. A simples presença de um, dois ou mais computadores na sala de aula não é suficiente para a qualidade do serviço. O cliente deseja que a instituição direcione o uso de computadores para aplicação prática e real.

Até o momento, o mercado tem aceitado positivamente o processo de expansão da Escola Parque Barra. As taxas de ocupação estão acima do esperado, mesmo com grande número de vagas sendo abertas a cada ano. A evolução, porém, tende a ser mais lenta após o período inicial. Desta forma, o serviço deve estar sempre em processo de aperfeiçoamento para garantir seu posicionamento no médio e longo prazo. O presente estudo aponta alguns objetivos a serem alcançados e mantidos, para que o processo de expansão continue fluindo positivamente e que a Escola Parque Barra defina melhor sua imagem no mercado. 
Mesmo com algumas distorções, o projeto pedagógico é entendido pela maioria do seu público atual e potencial. O problema com o projeto é a imagem de "indisciplina" que ele reflete para o mercado. Desta forma, deve se concentrar na discussão Liberdade de pensamento x Permissividade. A mensagem correta deve ser entendida por toda empresa, da diretoria ao porteiro, para que o contato com o cliente não deixe dúvidas ou inseguranças em relação a postura disciplinar da instituição. A divulgação dos resultados ajuda a melhorar a imagem que na Escola Parque Barra não existe cobrança nos estudos e que os estudantes fazem o que querem. Na verdade, a visão de uma das diretoras, é a imagem que escola quer ter: "Os alunos não fazem o que querem, querem o que fazem".

A inclinação para a gestão profissional com certeza evoluiu nos últimos anos, mas esbarra atualmente em um problema de aplicação prática. Existe uma distância grande, ainda, entre o que se sabe e deseja, e o que se faz. Para diminuir esta distância ou eliminar-la é preciso melhorar a comunicação interna e o comprometimento com as decisões tomadas. Na prática, a mensagem deve chegar no interlocutor de forma objetiva, com metas claras e mensuráveis a serem alcançadas. Paralelamente, deve ser feito controle e cobrança de maneira adequada.

Uma das marcas da escola é atenção individual com o aluno. O crescimento da unidade não deve significar a redução deste cuidado, que proporciona a identificação das dificuldades, problemas e necessidades dos alunos. O trabalho de fortalecimento da imagem é constituído por mudanças em alguns itens, como há "indisciplina”, mas também pela manutenção de itens como cuidado e atenção.

A estrutura física de qualidade é um requisito básico para uma escola do nível da Escola Parque Barra. É mais preocupante quando se lembra que o projeto pedagógico prevê a interação do aluno com o meio ambiente. A finalização das obras e os investimentos previstos em tecnologia são estratégias para se atingir uma estrutura física de qualidade.

A implantação de mudanças e estratégias deve ser acompanhada da organização dos processos básicos. Mais que simplesmente padronizar processos 
com normas e procedimentos existe a necessidade de se mudar a cultura da empresa, tornando a postura profissional uma competência básica presente em todos na empresa. 


\section{CAPÍTULO VI - GLOSSÁRIO}

PEM - Plano Estratégico de Marketing.

Demanda reprimida - Demanda maior do que a oferta.

Stakeholders - Indivíduos e grupos que influenciam e são influenciados pelas atividades de uma organização.

Survey - Pesquisa com questionários

Feedback - Retorno, resposta, retroalimentação.

Micromarketing - Marketing desenvolvido para um grupo pequeno de consumidores.

Commoditie - Produto ou serviço que não possui dificuldades para serem ofertados.

Boston Consulting Group - Consultoria com sede na Inglaterra.

Lucro presumido - Forma de tributação legal.

Mix de servicos - Composição de ofertas de uma empresa.

Pessoal de Frente - Funcionários que estabelecem contato direto com os clientes. 


\section{CAPÍTULO VII - BIBLIOGRAFIA}

CHURCHILL e PETER, "Criando Valor para O Cliente", Ed. Saraiva.

KOTLER, P. e FOX, KFA, “Marketing Estratégico para Instituições

Educacionais", Ed. Atlas (1994).

KOTLER, P. "Administração de Marketing", Prentice Hall (2000).

LEVITT, T. "Miopia Em Marketing", Harvard Business Review (jul/1960).

LOVELOCK, C. e W., "Serviços, Marketing, Gestão", Ed. Saraiva.

VERGARA, S. "Métodos de pesquisa em administração", Ed. Atlas (2005). 


\section{CAPÍTULO VIII - ANEXOS}

\section{ANEXO 01 - TAXA DE OCUPAÇÃO DAS VAGAS}

\begin{tabular}{|c|c|c|c|c|}
\hline & Ed. Infantil & Ens. Fund & Ens. Médio & Total Alunos \\
\hline \multicolumn{5}{|c|}{2002} \\
\hline Capacidade & 105 & 25 & 0 & 130 \\
\hline Alunos & 79 & 14 & 0 & 93 \\
\hline Vagas & 26 & 11 & 0 & 37 \\
\hline$\%$ vagas & $75,24 \%$ & $56,00 \%$ & - & $71,54 \%$ \\
\hline \multicolumn{5}{|c|}{2003} \\
\hline Capacidade & 170 & 50 & 0 & 220 \\
\hline Alunos & 158 & 51 & 0 & 209 \\
\hline Vagas & 12 & -1 & 0 & 11 \\
\hline$\%$ vagas & $92,94 \%$ & $102,00 \%$ & - & $95,00 \%$ \\
\hline \multicolumn{5}{|c|}{2004} \\
\hline Capacidade & 195 & 100 & 0 & 295 \\
\hline Alunos & 178 & 91 & 0 & 269 \\
\hline Vagas & 17 & 9 & 0 & 26 \\
\hline$\%$ vagas & $91,28 \%$ & $91,00 \%$ & - & $91,19 \%$ \\
\hline \multicolumn{5}{|c|}{2005} \\
\hline Capacidade & 242 & 185 & 35 & 462 \\
\hline Alunos & 244 & 176 & 32 & 452 \\
\hline Vagas & -2 & 9 & 3 & 10 \\
\hline$\%$ vagas & $100,83 \%$ & $95,14 \%$ & $91,43 \%$ & $97,84 \%$ \\
\hline \multicolumn{5}{|c|}{2006} \\
\hline Capacidade & 289 & 320 & 80 & 689 \\
\hline Alunos & 287 & 310 & 57 & 654 \\
\hline Vagas & 2 & 10 & 23 & 35 \\
\hline$\%$ vagas & $99,31 \%$ & $96,88 \%$ & $71,25 \%$ & $94,92 \%$ \\
\hline
\end{tabular}

TABELA 1 - TAXA DE OCUPAÇÃO DAS VAGAS

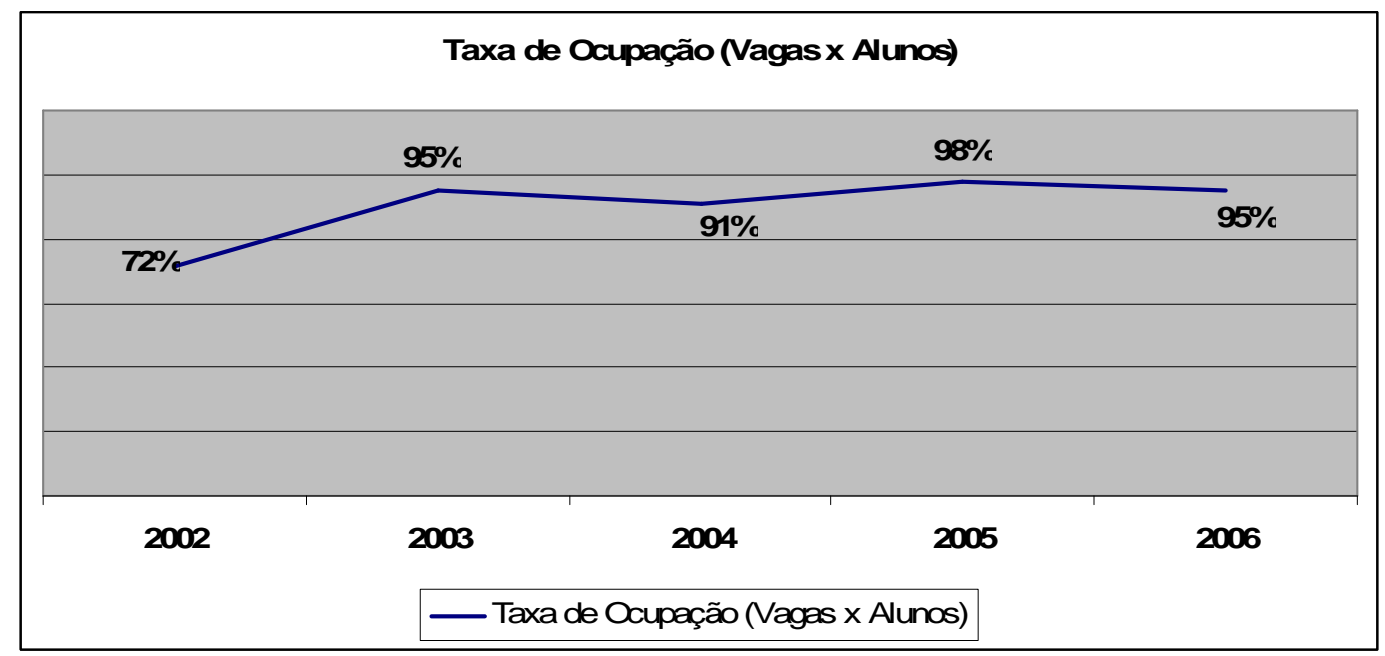

GRÁFICO 1 - TAXA DE OCUPAÇÃO (VAGAS X ALUNOS) 


\section{ANEXO 02 - TAXA DE VISITAS* X MATRÍCULAS (2003 A 2006)}

\begin{tabular}{|c|c|c|c|c|}
\hline & Ed. Infantil & Ens. Fund I & Ens. Médio & Total Alunos \\
\hline \multicolumn{5}{|c|}{2003} \\
\hline Visitas & 227 & 34 & 0 & 261 \\
\hline Matrículas & 69 & 23 & 0 & 92 \\
\hline TAXA & $30,4 \%$ & $67,6 \%$ & - & $35,2 \%$ \\
\hline \multicolumn{5}{|c|}{2004} \\
\hline Visitas & 145 & 62 & 0 & 207 \\
\hline Matrículas & 63 & 14 & 0 & 77 \\
\hline TAXA & $43,4 \%$ & $22,6 \%$ & - & $37,2 \%$ \\
\hline \multicolumn{5}{|c|}{2005} \\
\hline Visitas & 210 & 112 & 40 & 362 \\
\hline Matrículas & 108 & 53 & 32 & 193 \\
\hline TAXA & $51,4 \%$ & $47,3 \%$ & $80,0 \%$ & $53,3 \%$ \\
\hline \multicolumn{5}{|c|}{2006} \\
\hline Visitas & 262 & 130 & 33 & 425 \\
\hline Matrículas & 85 & 94 & 23 & 202 \\
\hline TAXA & $32,4 \%$ & $72,3 \%$ & $69,7 \%$ & $47,5 \%$ \\
\hline
\end{tabular}

TABELA 2 - TAXA DE VISITAS X MATRÍCULAS

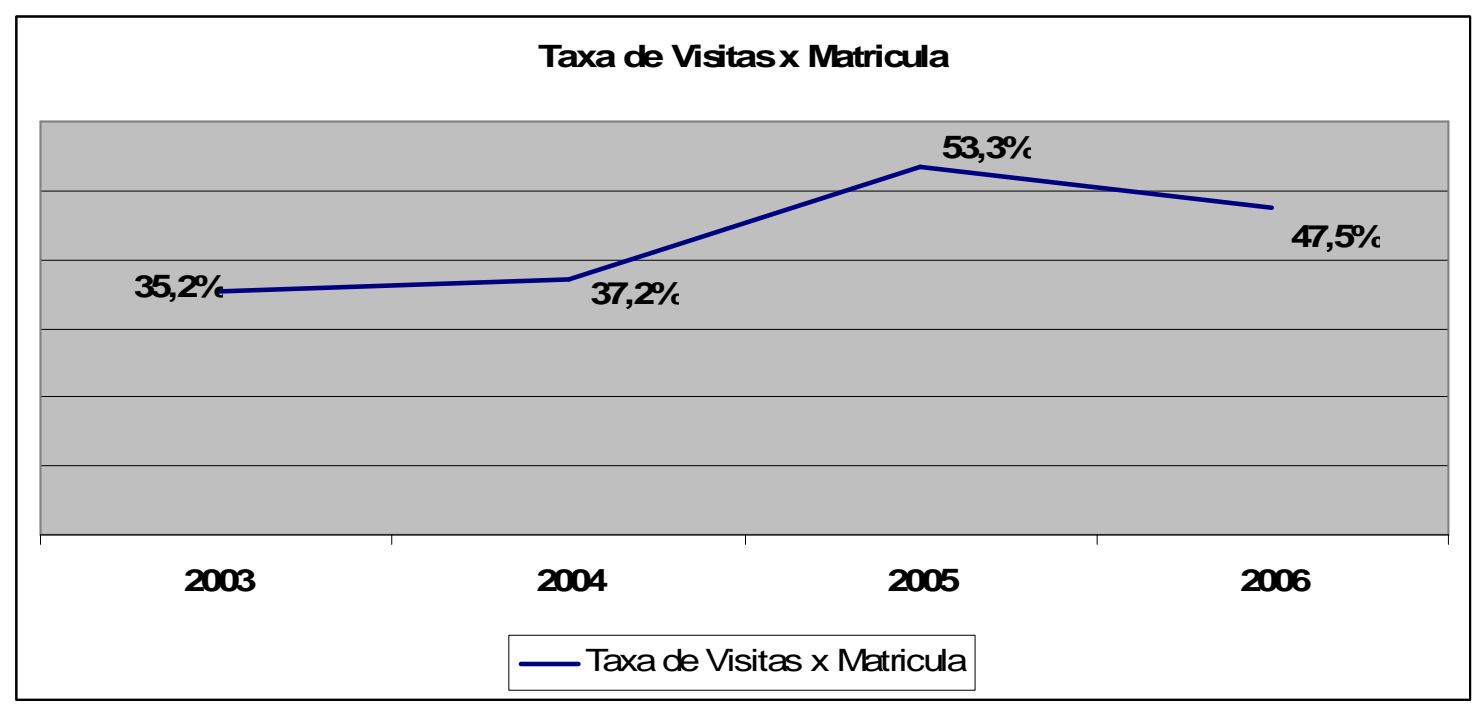

GRÁFICO 2 - TAXA DE VISITAS X MATRÍCULAS

* Visitas são computados quando os responsáveis pelo aluno vão até a Escola pedir algum tipo de informação. 
ANEXO 03 - COMPARATIVO PROFISSÕES UNIDADES DE NEGÓCIO

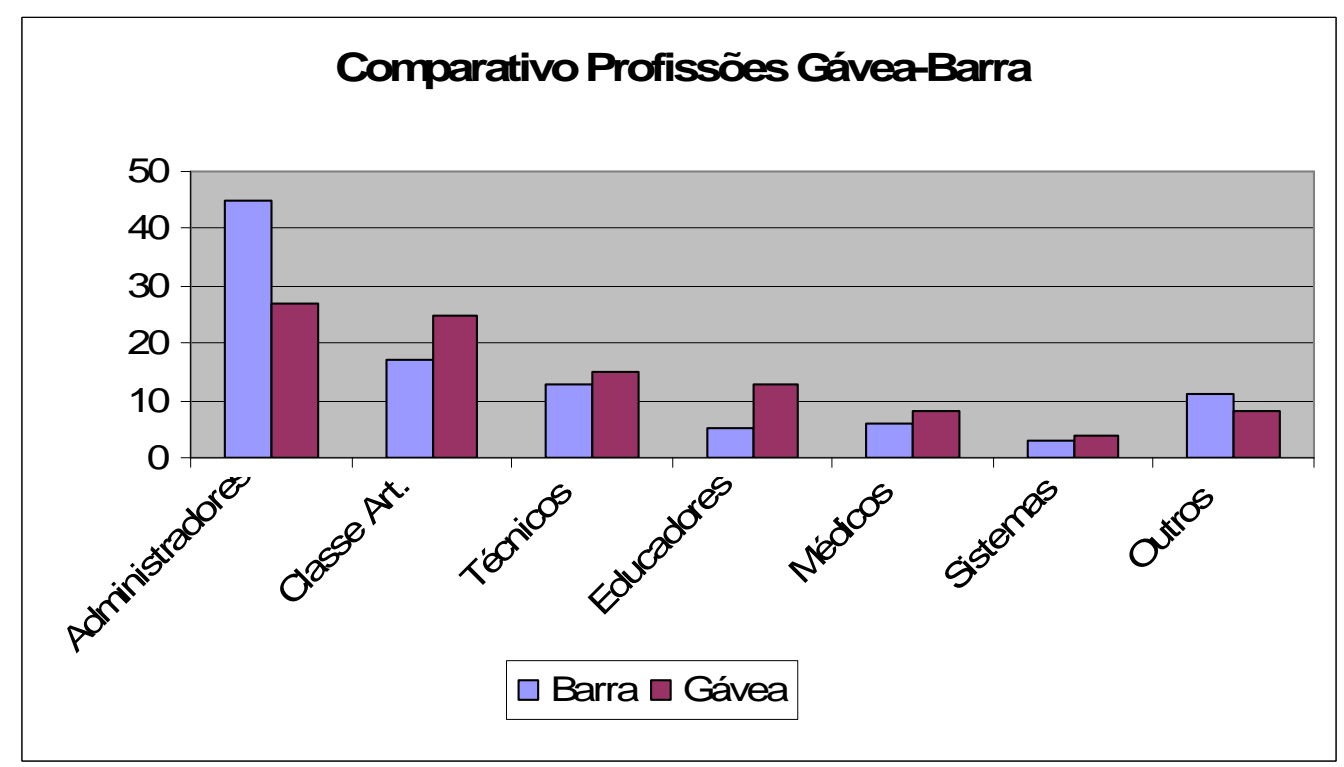

GRÁFICO 3 - COMPARATIVO PROFISSÕES UN'S

ANEXO 04 - DISTRIBUIÇÃO GEOGRÁFICA DAS RESIDÊNCIAS

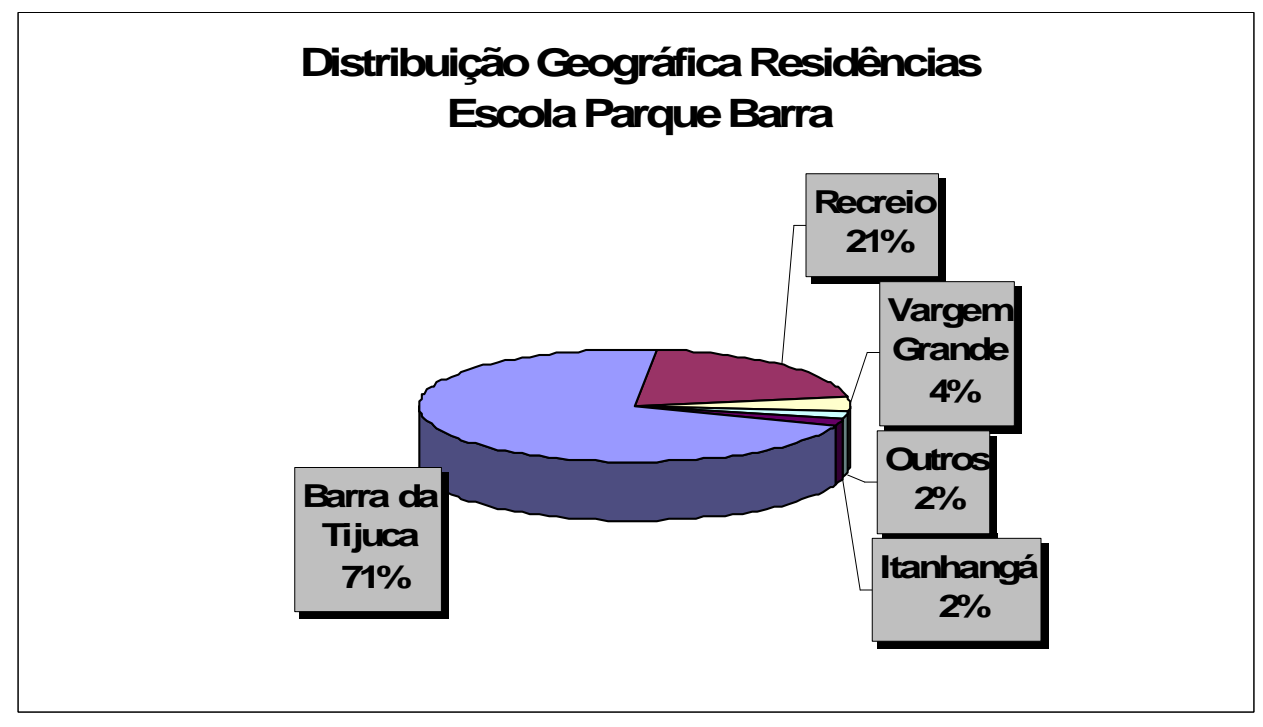

GRÁFICO 4 - DISTRIBUIÇÃO GEOGRÁFICA RESIDÊNCIAS

OBS.: A residência considerada é a que o aluno reside durante a semana 


\section{ANEXO 05 - CRESCIMENTO POPULACIONAL BARRA DA TIJUCA E RECREIO DOS BANDEIRANTES}

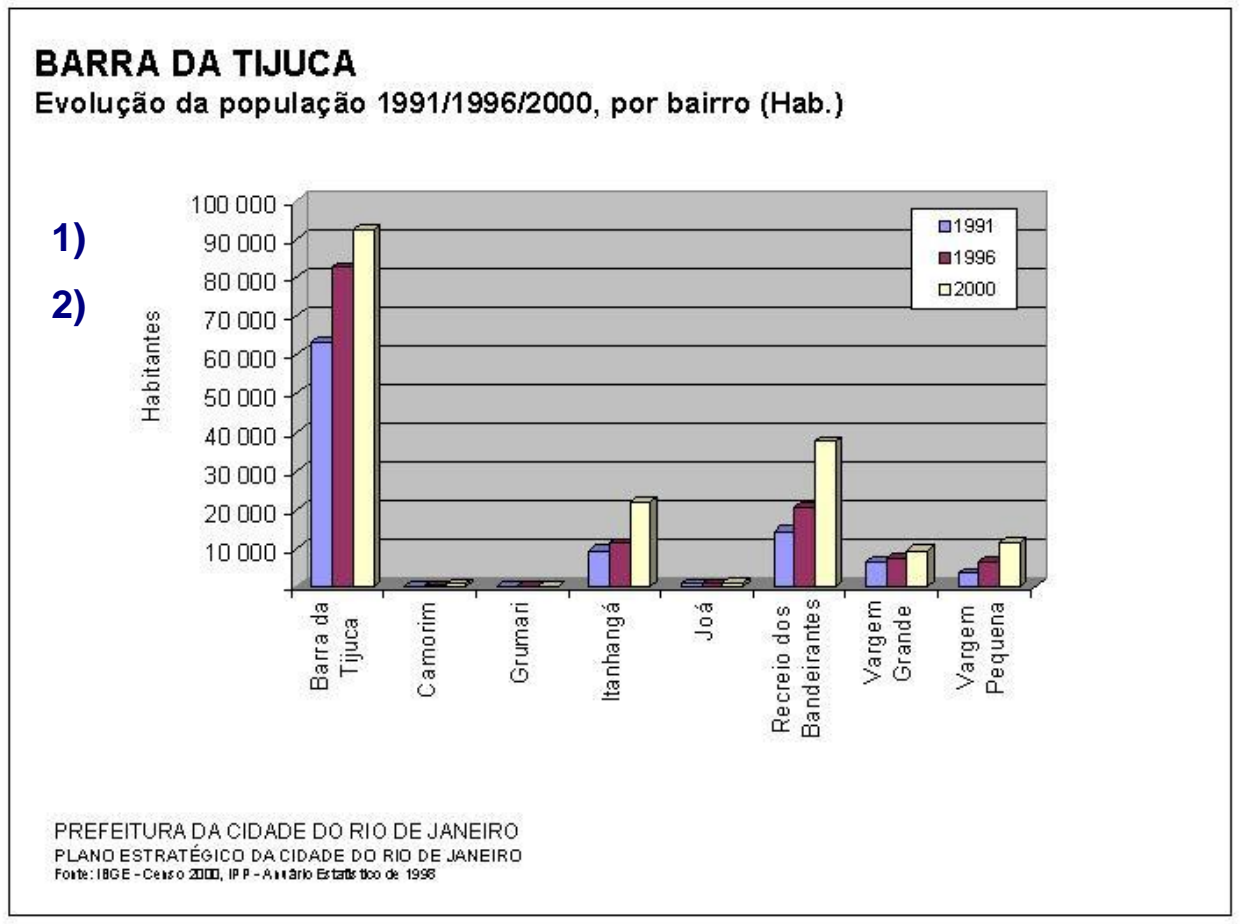

GRÁFICO 5 - CRESCIMENTO POPULACIONAL BARRA E RECREIO

No censo de 2000, realizado pelo IBGE (Instituto Brasileiro de Geografia e Estatística), o bairro da Barra da Tijuca possuía 92.233 habitantes. Utilizando a taxa de crescimento de 3,5 \% (1996 para 2000), estima-se o número de 117.000 habitantes, aproximadamente, em 2007. No Recreio dos Bandeirantes, em 2000, a população era de 38.000 habitantes. Utilizando a mesma taxa da Barra da Tijuca (as taxas de crescimentos do Recreio dos Bandeirantes ainda são muito irregulares), chega-se ao número estimado de 48.000 habitantes, aproximadamente, em 2007.

\section{ANEXO 06 - ESCOLAS PARTICULARES COM ACESSO À INTERNET (2003)}

\begin{tabular}{|c|r|r|r|r|r|c|}
\hline 2003 & \multicolumn{3}{|c|}{ Ensino Fundamental } & \multicolumn{3}{c|}{ Ensino Médio } \\
\hline & Total & Acesso à Internet & \multicolumn{1}{c|}{$(\%)$} & Total & Acesso à Internet & (\%) \\
\hline Brasil & 19.107 & 9.911 & $51,87 \%$ & 6.857 & 5.549 & $80,92 \%$ \\
\hline Sudeste & 7.747 & 5.376 & $69,39 \%$ & 3.437 & 3.107 & $90,40 \%$ \\
\hline Rio de Janeiro & 2.876 & 1.434 & $49,86 \%$ & 876 & 698 & $79,68 \%$ \\
\hline
\end{tabular}

TABELA 3 - ESCOLAS PARTICULARES COM INTERNET - "NÚMEROS DO ENSINO PRIVADO" FGV E IBGE - 2005/2006 


\section{ANEXO 07 - PESQUISA DE SATISFAÇÃO ESCOLA PARQUE BARRA}

Pesquisa contratada junto à empresa "Confirma", em outubro de 2004, buscava medir o nível de satisfação em diversos atributos dos serviços oferecidos pela Escola Parque Barra. A amostra incluiu 71 mães de alunos e foi realizada por telefone. Abaixo, questões relevantes filtradas.

Nível de Satisfação ( Média Grau de 1 a 10)

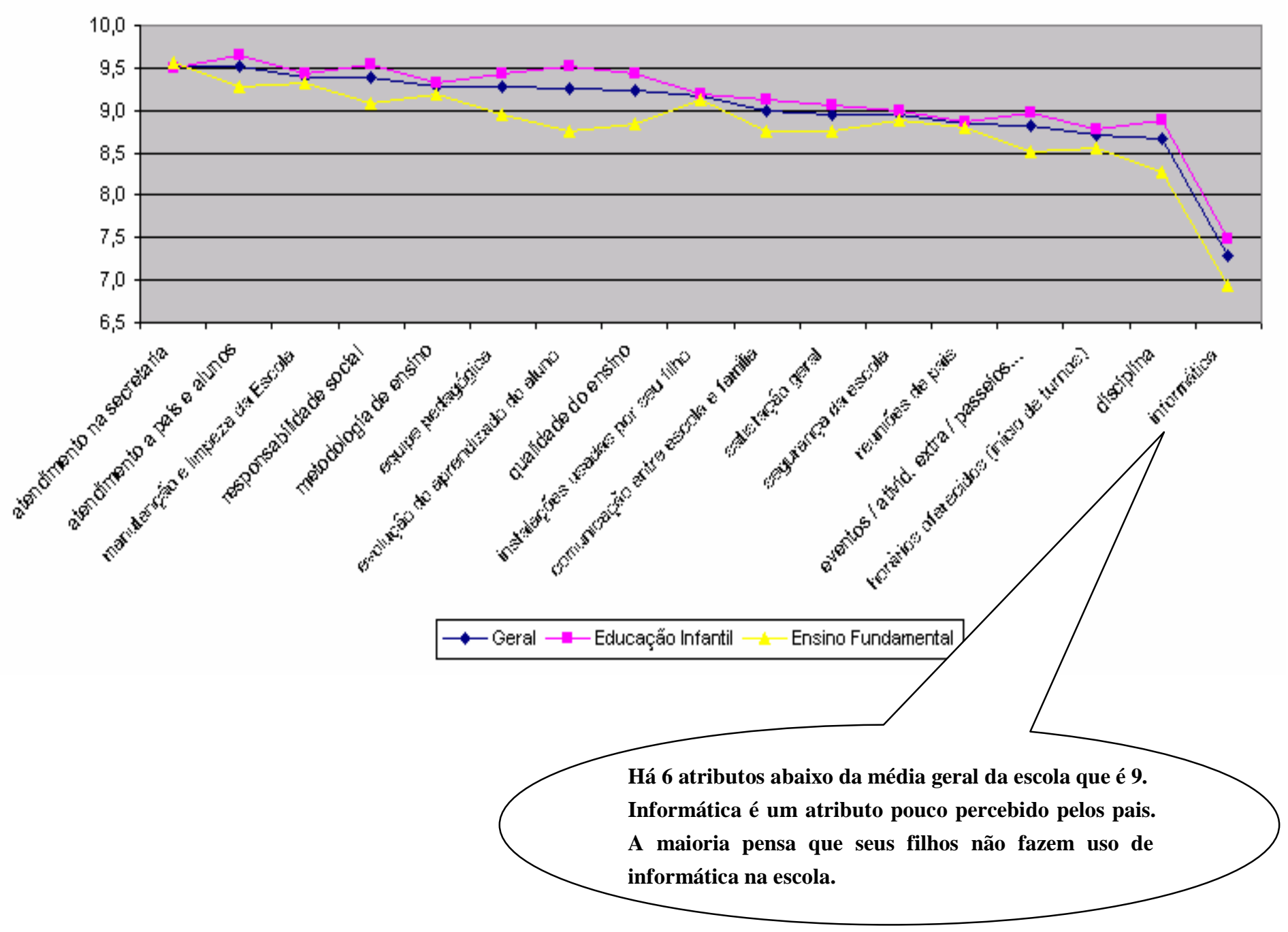




\section{Quais são as qualidades que a senhora mais valoriza nos profissionais que lidam com seu filho na EP?}

As características mais citadas são mais pessoais que profissionais.

\begin{tabular}{|r|c|c|}
\hline & Freqüência & Total \\
\hline Simpatia / carinho & 24 & 33,8 \\
\hline Saber lidar com criança & 21 & 29,6 \\
\hline Som nível de educação & 16 & 26,8 \\
\hline Paciência & 14 & 22,5 \\
\hline Dar atenção individualizada/ saber ouvir & 14 & 19,7 \\
\hline Dinamismo & 9 & 19,7 \\
\hline Tirar dúvidas & 6 & 8,5 \\
\hline Explicar bem & 6 & 8,5 \\
\hline Ter abertura/ transparência com alunos e pas & 5 & 7 \\
\hline Saber controlar a turma/ ter atitude firme & 5 & 7 \\
\hline Usar material variado & 4 & 5,6 \\
\hline Não sei & 4 & 5,6 \\
\hline Divertido em aula & 2 & 2,8 \\
\hline 2 & 2,8 \\
\hline Aplicar a metodologia da escola & 2 & 2,8 \\
\hline Saber falar português bem & 2 & 215,5 \\
\hline & 153 & \\
\hline & & \\
\hline
\end{tabular}

\section{O que a senhora mais gosta na EP?}

\begin{tabular}{|c|c|c|}
\hline & Freqüência & Total \\
\hline da metodologia / do ensino & 27 & 38,0 \\
\hline do espaço físico & 11 & 15,5 \\
\hline dos professores & 9 & 12,7 \\
\hline filha(o) adora a escola & 6 & 8,5 \\
\hline da direção & 3 & 4,2 \\
\hline Sou bem atendida & 3 & 4,2 \\
\hline a EP dá boa formação social aos alunos & 2 & 2,8 \\
\hline incentivam a parte cultural / artística & 2 & 2,8 \\
\hline Outros com uma menção cada & 8 & 11,3 \\
\hline Total & 71 & 100,0 \\
\hline
\end{tabular}


ANEXO 08 - LEVANTAMENTO DAS PREFERÊNCIAS DOS PAIS (SURVEY)

\begin{tabular}{|c|c|c|c|}
\hline & PERGUNTAS & RESPOSTAS & (\%) \\
\hline \multicolumn{4}{|c|}{ 1) Qual a importância do preço na escolha da escola para o seu filho? } \\
\hline a) & Pouco importante & 9 & $9,68 \%$ \\
\hline & Importante & 66 & $70,97 \%$ \\
\hline & Muito Importante & 12 & $12,90 \%$ \\
\hline & Indiferente & 6 & $6,45 \%$ \\
\hline \multicolumn{4}{|c|}{ II) Qual a importância da localização na escolha da escola para o seu filho? } \\
\hline & Pouco importante & 17 & $18,28 \%$ \\
\hline & Importante & 43 & $46,24 \%$ \\
\hline & Muito importante & 30 & $32,26 \%$ \\
\hline & Indiferente & 3 & $3,23 \%$ \\
\hline \multicolumn{4}{|c|}{ III) Qual a distância máxima que a escola pode estar localizada da sua residência? } \\
\hline & $3 \mathrm{~km}$ & 24 & $25,81 \%$ \\
\hline b) & $10 \mathrm{~km}$ & 30 & $32,26 \%$ \\
\hline c) & $20 \mathrm{~km}$ & 13 & $13,98 \%$ \\
\hline d) & Indiferente & 26 & $27,96 \%$ \\
\hline \multicolumn{4}{|c|}{ IV) Qual a importância da marca e da tradição da escola? } \\
\hline a) & Pouco importante & 20 & $21,51 \%$ \\
\hline & Importante & 34 & $36,56 \%$ \\
\hline & Muito importante & 29 & $31,18 \%$ \\
\hline d) & Indiferente & 10 & $10,75 \%$ \\
\hline \multicolumn{4}{|c|}{$\begin{array}{l}\text { V) É importante que seu filho curse a Ed. Infantil, o Ensino Fundamental e o Ensino Médio na mesma } \\
\text { escola? }\end{array}$} \\
\hline a) & Sim & 46 & $49,46 \%$ \\
\hline & Não & 23 & $24,73 \%$ \\
\hline c) & Indiferente & 24 & $25,81 \%$ \\
\hline \multicolumn{4}{|c|}{ VI) Você saberia descrever projeto pedagógico da Escola Parque Barra? } \\
\hline a) & $\operatorname{Sim}$ & 74 & $79,57 \%$ \\
\hline b) & Não & 19 & $20,43 \%$ \\
\hline
\end{tabular}

A pesquisa foi realizada entre os dias 03 e 07 de Julho de 2006 pela área administrativa da Escola Parque Barra via telefone. O público escolhido reuniu pais que já fizeram uma visita na escola em alguma ocasião e não matricularam seus filhos. No total, 93 pais foram entrevistados. 


\section{Gráficos - Respostas}

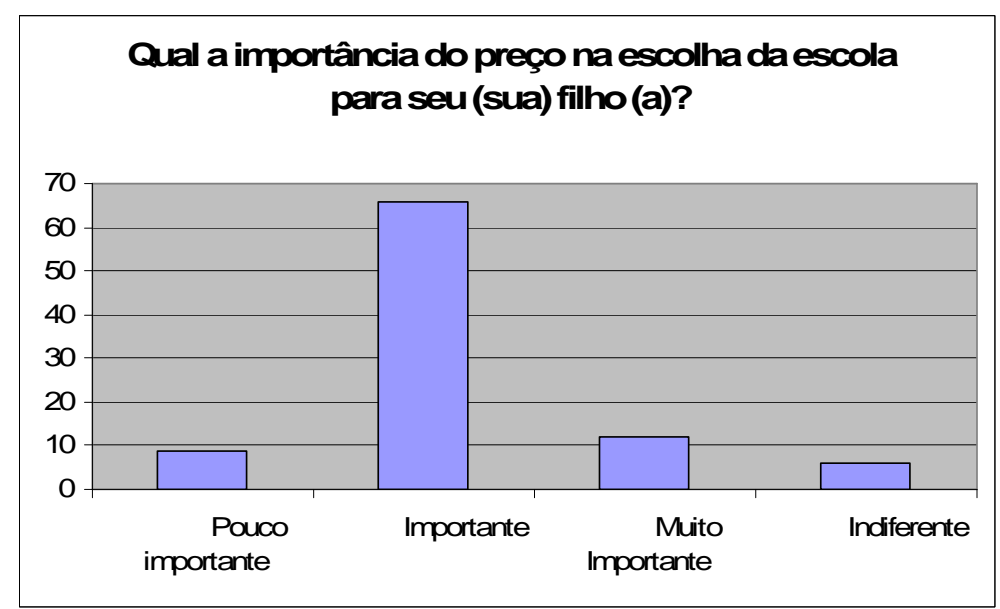

GRÁFICO 5 - PERGUNTA 1

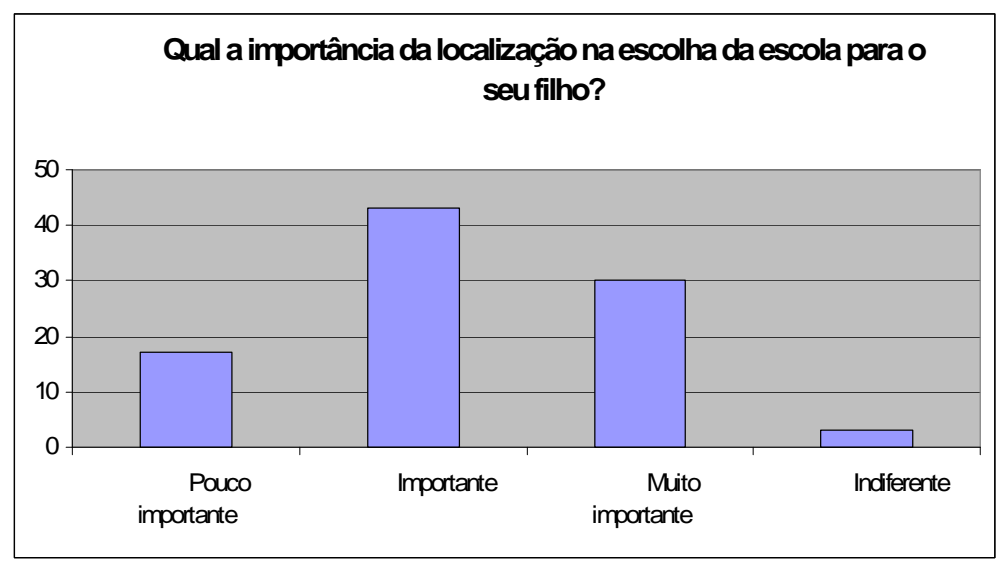

GRÁFICO 6 - PERGUNTA 2

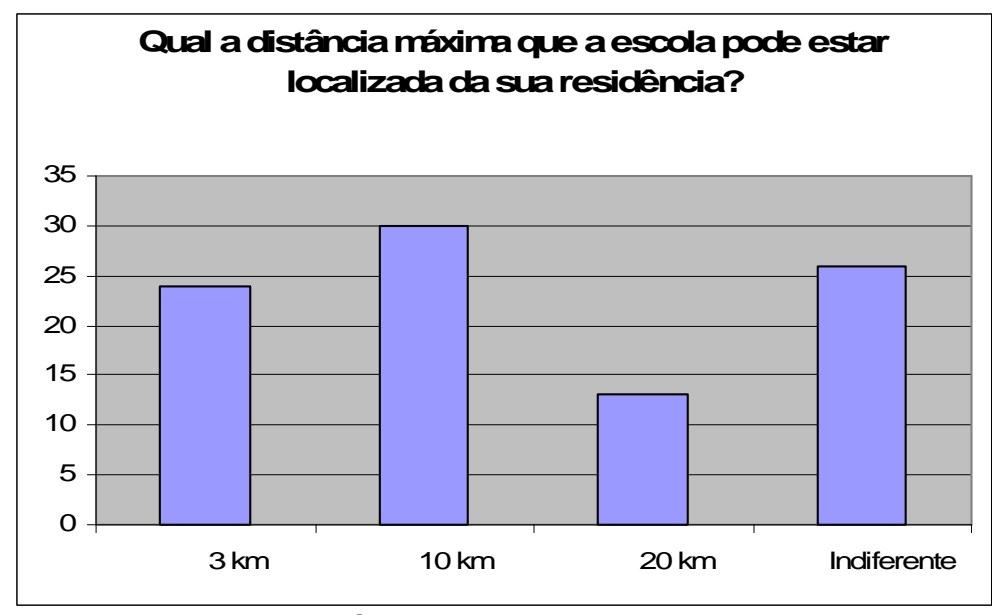

GRÁFICO 7 - PERGUNTA 3 


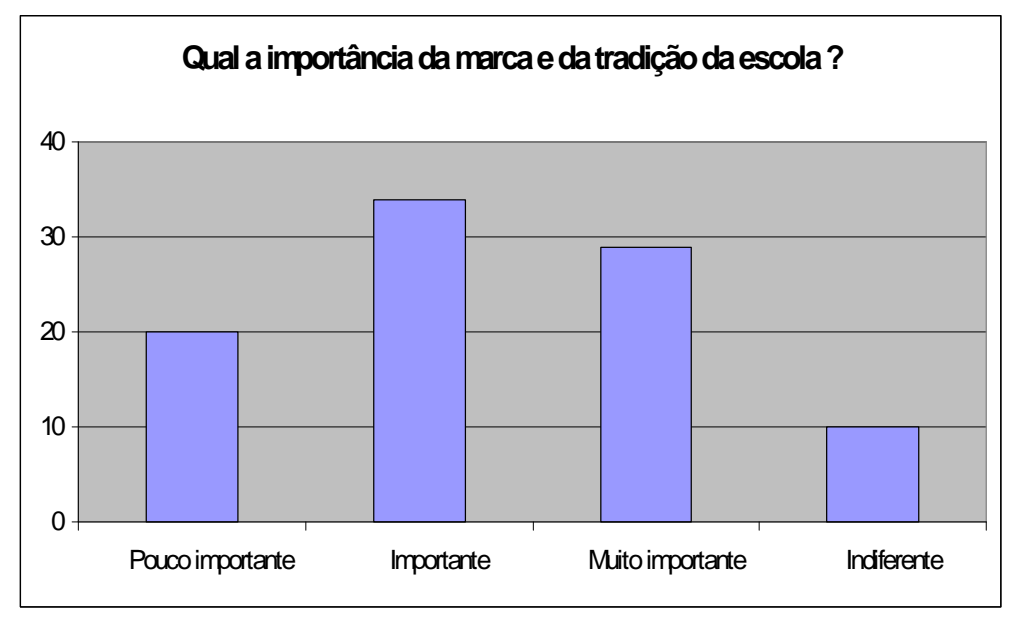

GRÁFICO 8 - PERGUNTA 4

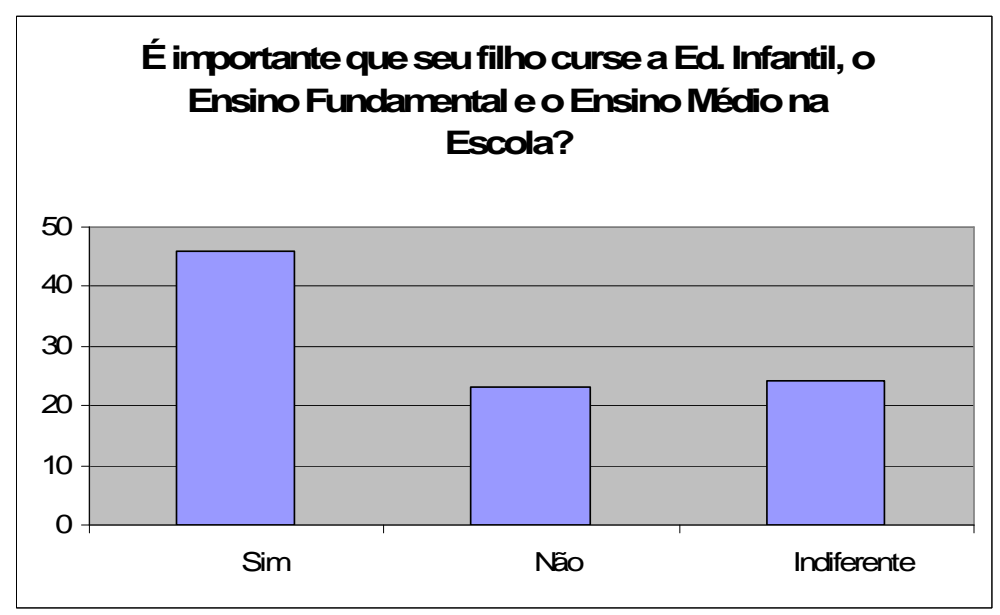

GRÁFICO 9 - PERGUNTA 5

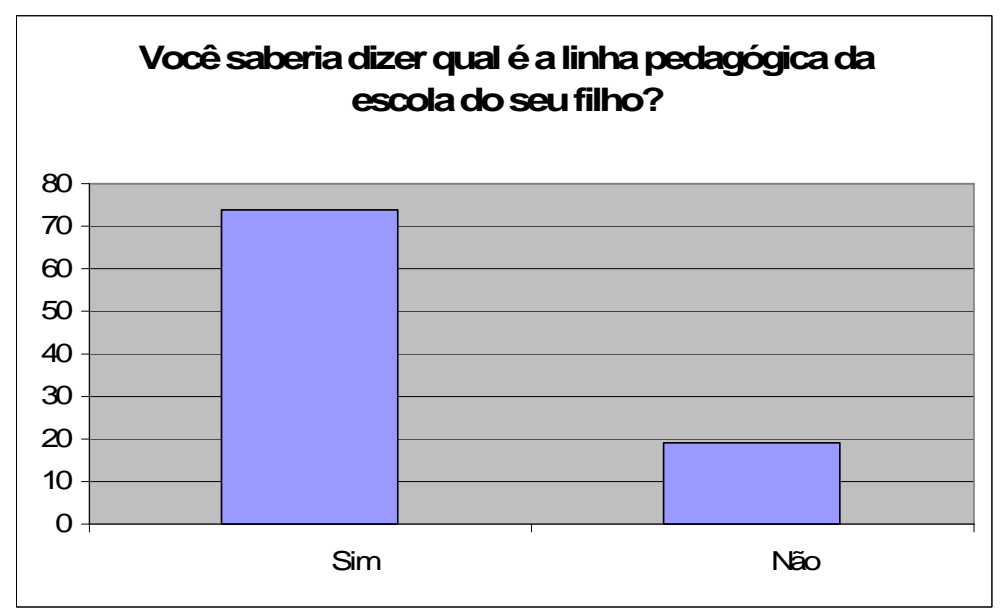

GRÁFICO 10 - PERGUNTA 6 


\section{ANEXO 09 - CRISE NO MERCADO CARIOCA (Estado de S.P. - 15/11/2003)}

\section{Caso mais recente éo do Gimk, criado ha 56 anos; outros colégios stăo desativando filtais}

\section{CLARISSA THOME}

$\mathrm{R}$ I0 - 0 estudante $\mathrm{Ra}$ fael Ribeiro estava na 5." série quando foi surrreendido pela noticia de que ua escola, a Canarinhos Ca. taiore, no Leblon (zona sil), nde estudava havia quatro nos, fecharia. Para não perder 5 amizades, combinou com os olegas e juntos mudarant-se ara o Grupo Integrado Magakna Kahn (Gimk), tambein o Leblon, onde estao descle 001. Hã uma semana, recebeam a má noticia. A tradicional scola, com 56 anos de histónia, ambém vai fechar.

"Nunca pensei que bso puesse acontecer de novo", recla1a Rafael, que sevestiude preu como os colegas para protesir contra a decisao da diretora a escola, Lygja Pereira da Sil a. Ela diz năo ter mais condioes de manter a escola por caut a da inadimplència de um tero dos alunos. "Estout tristíssi1ล. mas nåo posso continuar om a receita menor do que a espes", dizLygia.

Asituaço do Gimk na o éisoada. Nos illtimos dois anos feharam escolas tradicionais co100 Externato Săo Patricibeo ฉ̆o Domingos Alguns colégios ncerraram atividades de fiais, como 0 Săo Jos da Tijua, 0 Andrews e 0 Ang b Ameriano, ambos de Buafogo - este Itimo funciona até dia 19. No no passado, 80 escolas fechaam em todo o Estado. Este no, foram 96. e acordo com 0 indicato dos Es. abeleciment os e Ensino do Rb Sinepe Rio).

0 Gimk e o tio de escola em tie os ex-alunos 1atriculam sets Thos, o porteiro onhece todas as

EM 2 ANOS, ESTADO PERDEU 176

\section{COLEGIOS} rancas e a mensalidadeé das uais caras - cerca de R\$ 1000 . uli estudaram Caniza, o jorna sta PedroBial, o arquiteto Sério Bemardes, a cantora Preta iil. "E como a casa da gente. inheço as pesscas que edi1am meus filhos, porque foram

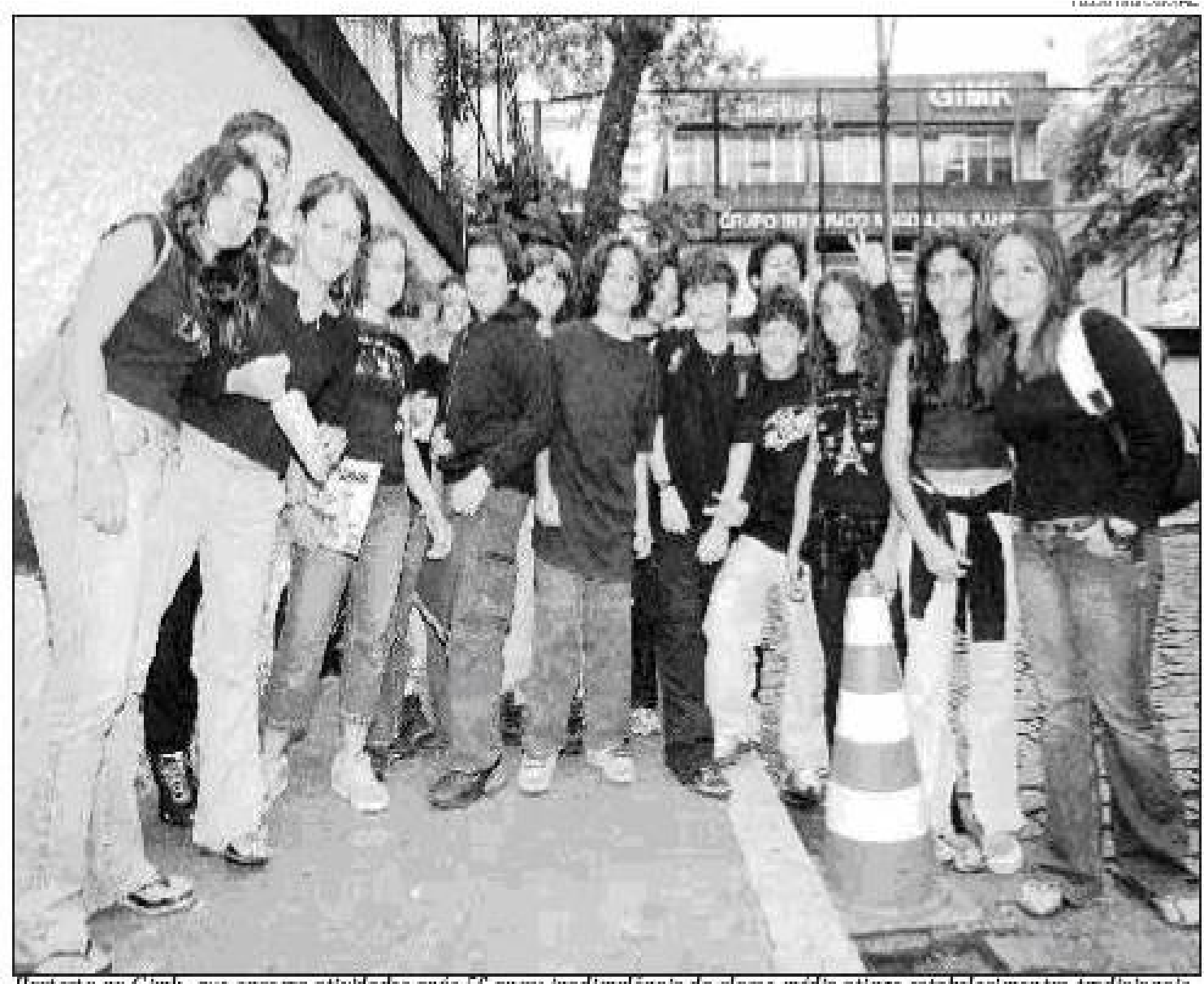

Protesto su Gink, pre encerra

meus professores", dizaex-aluna Flavia Bertrand, que mantinha très fillhos na escola.

Tristeza - "Todo mundo fica triste. Masteve pai quepagoua matrícula e nenhuma outra mensalidade. Nao há condiçós ${ }^{*}$, diz a coordentadora de funcionamento do Gimk, Dolo res Gonçalves, com 30 anos de casa. A criseda classemédia atin gitt 0 colégio nâo há mais o que famer. Esta mos tentando le vargrupos fecha dos para outras escolas para que os meninos กลa percam a identidade social", diz o presidente da Associacao de Pais e Alunos do Gi mk, Carbs Varaldo. Ele nego cia ainda a contrataça de funcionáribs e professores pebs c0légibs que receberem os estu- dantes do Gimk.

De acadb com o presidente do Sinepe-Rio. José Antônilo Teixeira, o que provoca a inadimplência, além da crise econômica, éo que chamou de "aumentona cesta de gastos da classe média". "A classe média ga $\$$ a entre Rs 280 a R\$ 320 com novas tecnologias, como Internet, tevè a cabo, celitlar. Issonão existia há cino anos. Essa mudanca de hábito ea crise econômica faxem com que as familias deixem de ver a educaçăo como pribridade", diz.

A inadimplència de $20 \%$ dos alunos $\mathrm{e} o$ aimmento do aluguel deR $\$ 70$ mil para R\$ 130 mill $\mathbf{k}$ varam a direcao do Anglo Ame. ricano a fechar aunidade de Botafogo, que está ali há 30 anose tem 576 alunos, que pagam cerca de R\$ 650 de mensalidade. "Nao sei nem como me comportar fora daqui", resuniu Alberto Marino, de 17 anos, alıno do Angb há 13 anos.

Trabalhamos num prédio centenário, manutençao cara e aluguel abusivo. Nâo tinha razko para permanecer ali se temos dois prédios próprios na Barra da Tíuca", diz a diretora-geral Líndalúcia Poncione Paraimo.

Categeria - A socialite Carmem Mayrink Veiga lamenton o fechamento de escolas tradicionais. "E uma perda fechar tido o que é tradicional. Meus filhos Antônio e Antenor estudaram 10 anos $m$ S๙ॅo Patricio. Nø๊o erauma escola so fisticada. mas de primeirissima categoria. Seas excolas tradicionlak es tăo fechando, para onde yă os nossos estudantes? ? indagou.

De acordo com 0 IBGE, eles continuam nas escolas particulares, mas nas mais baratas. $\mathrm{E}$ o que diagnosticou a Pesquisa Nacional por Amostra de Do. micilio (PNAD) de 2002. Em 2001 , dos 20.526.938 estudantes com mais de 5 anos na regia 0 Sudeste, $21,3 \%$ estuda- vain em escolas particulares. No ano seguinte, o nummero de alumos nessa faixa etária stibiu para 20.568.075, e o percentual de estudantes que pagavam por educaçăo tambem cresceu: 22,2\%.

A atriz Carolina Dieckman foi alına do Anglo e também nâo gostou de saber que o prédio centenário será devolvido ao proprietário. a Santa Casa de Misericórdia. "Fui muito feliz no Anglo. É uma escola que trata muito bem seus alunos e com muito carinho. Foi lá que comecei a praticar um dos esportes que mais gosto, a ginás ica olimpica", lembra.

A também atriz Renata Nascimento, de 12 anos, a Mônica de Maharao, é outra exahuna do Anglo. "Só sai de la porque me mudei para a Barra. Existem escolas enormes em que vocé é apenas uma matricula. Lá eles conheciam a gente pelo nome Fico muito triste", resumili. 


\section{ANEXO 10 - PROJETO PEDAGÓGICO}

A Escola Parque define sua finalidade pedagógica na formação de pessoas para participarem ativamente da sociedade. Fundamenta sua ação educativa em três objetivos básicos:

Formar alunos para o exercício da cidadania. Este objetivo compreende, além da formação básica, o relacionamento com os outros alunos e funcionários da escola, bem como em projetos específicos. Como exemplo, alunos da Escola são responsáveis pelo curso pré-vestibular comunitário para alunos carentes na sede da Gávea. No passado, os alunos foram estimulados a participar da "ECO 92" e foram levados a conhecer um acampamento do MST (Movimento dos Sem-Terra).

Formar alunos que superem o pensamento de senso comum. Utiliza-se 0 exercício da capacidade de pensar, possibilitando criar soluções para enfrentar um mundo em transição.

Formar pessoas para a conquista de autonomia moral e intelectual. Foco na participação social vista como um dever que se cumpre com prazer e orgulho.

A ação educacional da Escola Parque baseia-se nas Teorias Construtivistas do Conhecimento, comumente atribuída ao professor Jean Piaget com a importante contribuição do professor Lev Vygotsky. Segundo Piaget, os indivíduos constroem seus conhecimentos a partir de suas experiências, através de processos de acomodação e assimilação. Os alunos aprendem pela experimentação, em senso amplo, ou pela formulação de hipóteses, não porque são ensinados ou treinados. Vygotsky indica a importância do meio no desenvolvimento da construção do conhecimento.

A Teoria do Construtivismo não é um método pedagógico. Piaget não orienta o que ensinar, mas permite que se compreenda como a criança ou o adolescente aprendem. A criança constrói seu próprio conhecimento através de sua integração com o mundo. Os professores se propõem a desenvolver esta capacidade, 
acompanhando os alunos nesta construção do pensamento, não apenas treinando modelos prontos.

O ponto de partida metodológico da Escola Parque é a problematização e aprofundamento da reflexão. O aluno é levado a estabelecer relações entre conhecimentos, promove-se a problematização do cotidiano ou de temas amplos pela criação de projetos, por aulas expositivas, por propostas de pesquisas, além de palestras e seminários.

A proposta pedagógica baseia-se nas sugestões dos Parâmetros Curriculares Nacionais (PCN), descritas na Lei de Diretrizes e Bases 9394/96, na qual turmas são agrupadas por idade próxima no segmento de educação infantil e seriadas a partir do ensino fundamental.

A pedagogia de projetos é adotada até a 8ª série do ensino fundamental, possibilitando o maior engajamento do aluno, o interessando na solução de problemas. Através da participação na análise, estudo dos temas e conteúdos propostos, são ativadas as competências cognitivas. A partir da $8^{\underline{a}}$ série, propõe-se o aprofundamento do pensamento abstrato. Estimula-se a autonomia do estudo. No $3^{0}$ ano do ensino médio, a carga horária é extensa, com aulas de aperfeiçoamento à tarde, para melhor preparar os alunos para as provas de acesso à universidade. 


\section{ANEXO 11 - GRADE CURRICULAR MEC}

\begin{tabular}{|r|}
\hline EDUCAÇÃO INFANTIL \\
\hline Infantil 1 \\
\hline Infantil 2 \\
\hline Infantil 3 \\
\hline ENSINO FUNDAMENTAL I \\
\hline $1^{\circ}$ Série \\
\hline $2^{\circ}$ Série \\
\hline $3^{\circ}$ Série \\
\hline $4^{\circ}$ Série \\
\hline ENSINO FUNDAMENTAL II \\
\hline $5^{\circ}$ Série \\
\hline $6^{\circ}$ Série \\
\hline $7^{\circ}$ Série \\
\hline $8^{\circ}$ Série \\
\hline $1^{\circ}$ Ano \\
\hline $2^{\circ}$ Ano \\
\hline $3^{\circ}$ Ano \\
\hline
\end{tabular}

\section{ANEXO 12 - ENEM (Exame Nacional do Ensino Médio)}

\begin{tabular}{|c|c|}
\hline \multirow{10}{*}{ 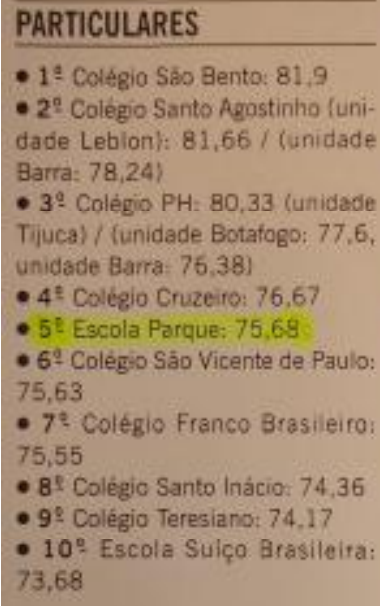 } & \multirow{8}{*}{ 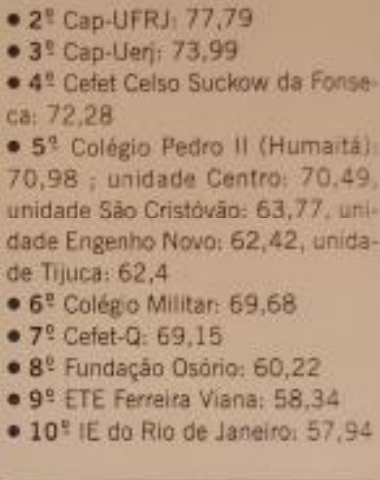 } \\
\hline & \\
\hline & \\
\hline & \\
\hline & \\
\hline & \\
\hline & \\
\hline & \\
\hline & PIOR PARTICULAR \\
\hline & $\begin{array}{l}\text { - Escola Rene: } 33,09 \text { (com corre- } \\
\text { द̧ắ) }\end{array}$ \\
\hline PUBLICAS & PIOR PÚBLICA \\
\hline $\begin{array}{l}\text { - 12 Escola Politécrnica de Saúde } \\
\text { joaquim Venảncio: } 79,02\end{array}$ & $\begin{array}{l}\text { - EEES Escola Duque de Caxias } \\
\text { (estadual): } 27,39 \text { (com conreça) }\end{array}$ \\
\hline 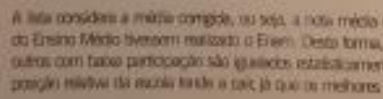 & 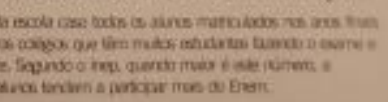 \\
\hline
\end{tabular}

O Exame aplicado pelo MEC é realizado nas turmas de ensino médio das escolas. Além de ser um indicador de qualidade das escolas, funciona como uma das portas de ingresso às faculdades particulares.

No ano de 2005, a Escola Parque posicionou-se na quinta posição entre as escolas particulares do Estado do Rio de Janeiro. 


\section{ANEXO 13 - VESTIBULAR COMUNITÁRIO}

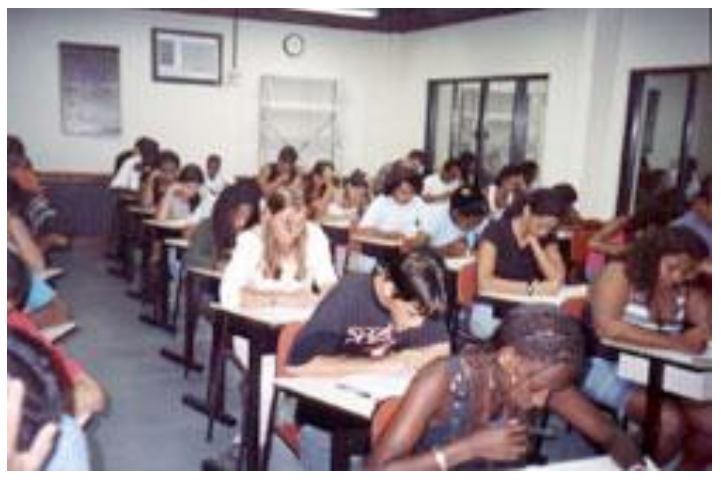

O Projeto de Educação Comunitária da Escola Parque, o PECEP, envolve alunos, ex-alunos e professores. Atualmente, é desenvolvido pela unidade da Gávea, e está sendo implantado na Barra.

No ano de 2005, 18 alunos foram aprovados e ingressaram em faculdades públicas e particulares, que oferecem bolsas.

\section{ANEXO 14 - QUESTÕES LEGAIS}

Cesar quer $\quad$ vender $\quad$ terrenos
07/07/2006 - O Globo

Moradores já conseguiram impedir posto de gasolina

É o que consta num documento da Superintendência de Patrimônio Imobiliário da Secretaria municipal de Fazenda encaminhado ao vereador Luiz Guaraná (PSDB), presidente da Comissão de Assuntos Urbanos da Câmara, em resposta a um requerimento de informações. O mesmo documento afirma que um outro terreno no Novo Leblon, com 3.500 metros quadrados, que deveria receber um jardim, poderá abrigar casas ou comércio. A mudança na destinação das áreas preocupa os moradores do condomínio.

- Há alguns anos, um posto de gasolina tentou ocupar uma dessas áreas. Os moradores se rebelaram e o posto não veio. Se a prefeitura quiser vender o terreno, pelo qual pagamos cinco mil Ufirs para usarmos, vai ter resistência - prevê Francisco Eduardo Ribeiro, ex- administrador do condomínio.

Segundo o secretário de Urbanismo, Augusto Ivan, a mudança na destinação dos terrenos é legal. Ele explica que, uma vez concretizada a venda, deixa de valer a destinação estipulada no PAL e o comprador pode construir o que achar melhor, desde que seja permitido pela legislação urbanística.

A vereadora Tereza Bergher (PFL) discorda e diz que pedirá explicações à prefeitura: 
- Se a área é destinada à construção de uma escola, a prefeitura não pode vender o terreno e permitir prédios.

Ivan faz a ressalva, no entanto, de que a aprovação para a construção de prédios na atual Praça do Novo Leblon dependeria de um estudo detalhado da secretaria.

O arquiteto Canagé Vilhena, presidente da ONG Centro das Cidades e membro do Crea-RJ, é um dos que discordam do secretário. Segundo ele, praças e jardins são bens de uso comum do povo e não poderiam, portanto, ter a destinação alterada. Na sua opinião, o projeto, apesar de legal, é imoral.

- O empreendedor do Novo Leblon, para fazer o loteamento, foi obrigado a doar terrenos para a cidade. A prefeitura, que os recebeu gratuitamente, quer agora colocá-los no mercado imobiliário. É especulação.

Presidente da Câmara Comunitária da Barra, Delair Dumbrosck também acha o projeto polêmico:

- O empreendedor teve que doar terrenos para a prefeitura. Agora, ela quer vendê-los e permitir a construção de prédios que o empreendedor não pôde erguer. Ele vai ser indenizado?

O maior terreno que a prefeitura pretende vender, com 33,9 mil metros quadrados, avaliado em $\mathrm{R} \$ 34,2$ milhões, fica no Centro Metropolitano, na Barra, área concebia pelo arquiteto Lúcio Costa para abrigar o novo Centro da cidade. Ele deveria receber programas específicos da prefeitura, como creches e postos de saúde. Os terrenos onde funcionam o Colégio Anglo-Americano e CEL também podem ser vendidos, assim como área nos condomínios Bosque de Marapendi e Pedra de Itaúna. Um outro local à venda, na Avenida das Américas, alugado ano passado à concessionária Eurobarra, que pretende construir outro empreendimento no local, chamou a atenção de Guaraná. O valor sugerido para a venda é R\$ 3 milhões, menos do que o aluguel cobrado, de R\$ 4 milhões, pelo prazo de 20 anos. Por esses motivos, o vereador já anunciou que dará parecer contrário ao projeto. Ele pretende convocar na próxima semana uma audiência pública para discutir a questão.

- A prefeitura não pode viver de comércio de terreno. É um absurdo o prefeito, por problemas de caixa, querer arrecadar R\$ 109 milhões assim.

\section{Prefeito diz que Câmara pode arquivar projeto}

Cesar Maia disse que a Câmara pode arquivar a proposta:

- A decisão será exclusivamente dos vereadores. Se fosse um decreto, creio que teriam toda a razão (de reclamar). Se fosse uma medida provisória, idem. Mas é um simples encaminhamento.

Cesar afirmou ainda que a intenção com a venda dos terrenos é desmobilizar ativos cuja destinação nunca será de interesse público ou social. Na mensagem enviada à Câmara, em novembro de 2005, o prefeito disse que os imóveis listados não estavam sendo usados por não servirem a seus fins ou porque estavam subutilizados, sendo até alvo de invasões. Augusto I van cita a praça e o jardim no Novo Leblon como exemplos:

- A Barra tem condomínios com área de lazer própria. Uma praça na Avenida das Américas não é necessária. A melhor alternativa é que o terreno seja vendido e a receita, aplicada em obras e na melhoria de hospitais e escolas. 